Florida International University FIU Digital Commons

\title{
Azúcar agridulce: memoria, discursos y paisajes azucareros en la nación y la cultura cubana (1791-2017)
}

Deborah Gomez

dgome027@fiu.edu

DOI: $10.25148 /$ etd.FIDC006874

Follow this and additional works at: https:// digitalcommons.fiu.edu/etd

Part of the Latin American History Commons, Latin American Literature Commons, Modern Languages Commons, and the Spanish Literature Commons

\section{Recommended Citation}

Gomez, Deborah, "Azúcar agridulce: memoria, discursos y paisajes azucareros en la nación y la cultura cubana (1791-2017)" (2018). FIU Electronic Theses and Dissertations. 3761.

https://digitalcommons.fiu.edu/etd/3761 


\section{FLORIDA INTERNATIONAL UNIVERSITY}

Miami, Florida

\section{AZÚCAR AGRIDULCE: MEMORIA, DISCURSOS Y PAISAJES AZUCAREROS}

EN LA NACIÓN Y LA CULTURA CUBANA (1791-2017)

A dissertation submitted in partial fulfillment of

the requirements for the degree of

DOCTOR IN PHILOSOPHY

in

SPANISH

by

Déborah Gómez

2018 
To: Dean John F. Stack, Jr.

Green School of International and Public Affairs

This dissertation, written by Déborah Gómez, and entitled Azúcar agridulce: memoria, discursos y paisajes azucareros en la nación y la cultura cubana (1791-2017), having been approved in respect to style and intellectual content, is referred to you for judgment.

We have read this dissertation and recommend that it be approved.

María Asunción Gómez

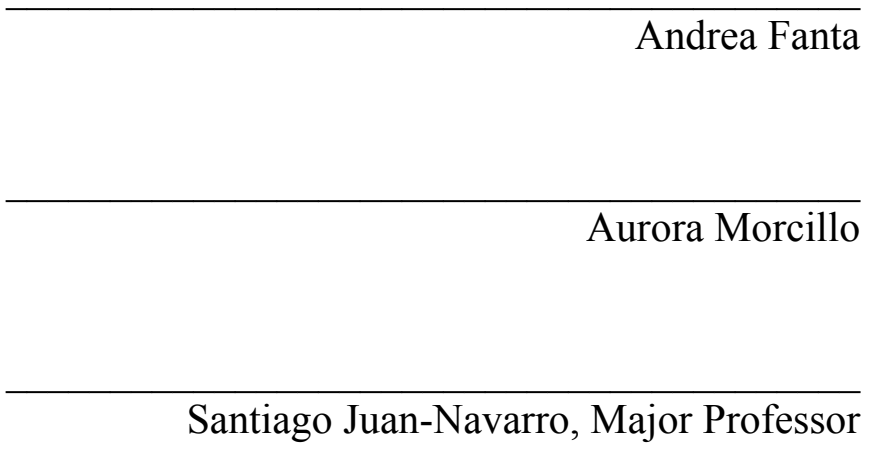

Date of Defense: April 27, 2018

The dissertation of Déborah Gómez is approved.

Dean John F. Stack, Jr. Green School of International and Public Affairs

Andrés G. Gil Vice President for Research and Economic Development and Dean of the University Graduate School

Florida International University, 2018 
C Copyright 2018 by Déborah Gómez

All rights reserved. 


\section{DEDICATION}

A mi madre y a Bibi, por todo el amor y el apoyo que me han ofrecido durante esta etapa

de mi vida y por siempre haber creído en mí, y a Licet, por las incontables horas dedicadas a este proyecto y por sus siempre oportunos comentarios. 


\section{ACKNOWLEDGMENTS}

Le agradezco infinitamente a los profesores que integraron el comité de esta tesis, Dra. María Asunción Gómez, Dra. Aurora Morcillo, Dra. Andrea Fanta y Dr. Santiago Juan-Navarro, por el tiempo que me dedicaron y el apoyo que me ofrecieron durante este proyecto.

Mi especial agradecimiento al Dr. Juan-Navarro por interesarse en mi estudio y dirigir tan acertadamente esta investigación y a la Dra. Gómez por su incondicional ayuda durante todos estos años.

Aprovecho la ocasión para agradecerle a la Dra. Melissa Baralt, quien, aunque no haya sido miembro de este comité, me ha apoyado durante toda mi carrera y siempre ha creído en mí.

Quiero también agradecerle a las siguientes instituciones de Florida International University: Department of Modern Languages, por ofrecerme el Teaching Assistantship durante los primeros años de mis estudios de doctorado; Kimberly Green Latin American and Caribbean Center, por concederme el Tinker Field Research Grant, gracias al cual pude viajar a Cuba para realizar parte de esta investigación, y al University Graduate School, por otorgarme el Doctoral Evidence Acquisition Fellowship y el Dissertation Year Fellowship, los cuales me permitieron terminar de reunir y analizar el material de estudio que sirvió como base para escribir esta tesis. 


\section{ABSTRACT OF THE DISSERTATION \\ AZÚCAR AGRIDULCE: MEMORIA, DISCURSOS Y PAISAJES AZUCAREROS \\ EN LA NACIÓN Y LA CULTURA CUBANA (1791-2017)}

by

\section{Déborah Gómez}

Florida International University, 2018

Miami, Florida

\section{Professor Santiago Juan-Navarro, Major Professor}

El cierre y desmantelamiento de gran parte de los centrales azucareros cubanos con la llegada del milenio, que se puede definir como la debacle azucarera, creó dos urgencias. Por un lado, la pérdida de los referentes culturales produjo un vacío, un trauma, un desarraigo, que clamaba por un espacio de representación. Por el otro, esta misma experiencia desgarradora creó la necesidad de rescatar el papel que el azúcar había jugado en la Historia, la identidad y la cultura cubana.

El presente estudio, además de examinar varias de las obras que se produjeron en respuesta a la debacle azucarera, también intenta responder a esa segunda necesidad, reflexionando acerca de la presencia del azúcar en Cuba, a través del análisis de un amplio corpus unificado por “el motivo del azúcar". Partiendo de estudios fundamentales en torno a la historia del azúcar en Cuba (Ortiz 1940, Moreno Fraginals 1978, Benítez Rojo 1998 y 2010), en este estudio exploro la presencia constante y totalizadora del azúcar en la nación, sistematizando e integrando, en un corpus concreto, un conjunto de textos heterogéneos con el azúcar como denominador común. Además de identificar y deslindar este corpus, mi estudio lo inserta y lo discute en el amplio marco histórico 
referencial del devenir del azúcar como símbolo de la nación cubana, estableciendo un diálogo enriquecedor y productivo entre los textos, su contexto de producción y el contexto histórico general en que este corpus azucarero se gesta. Como parte de esa discusión, mi trabajo documenta y destaca la relevancia que, desde el punto de vista histórico y político, debe adjudicársele a un grupo de obras recientes, surgidas en respuesta a la reestructuración, llamando la atención hacia la importancia capital de estos textos para la reconstrucción fidedigna del impacto humano causado por la debacle azucarera cubana. 


\section{TABLE OF CONTENTS}

CHAPTER

PAGE

INTRODUCCIÓN 1

1. LA REESTRUCTURACIÓN AZUCARERA DENTRO DEL DISCURSO HISTÓRICO REVOLUCIONARIO: CÓMO SE PERCIBE EL PROCESO SEGÚN EL DISCURSO OFICIAL

1.1. Los textos y la prensa oficialistas: la versión monumental y triunfalista de la reestructuración

1.2. La intelectualidad comprometida: el futuro y la memoria del azúcar entre la preocupación real y el compromiso político

2. AZÚCAR, NACIÓN Y PAISAJES EN LA ERA COLONIAL: INFLUENCIA DE LA AGROINDUSTRIA AZUCARERA EN LA INDENTIDAD Y LA MANIFESTACIÓN CULTURAL NACIONALES 39

2.1. Textos históricos y jurídico-económicos fundacionales: el temor al negro y la imaginada nación blanca en los discursos azucareros de la época

2.2. Los paisajes culturales de la nostalgia en la poesía del exilio de José María Heredia: la exclusión de la caña dentro la simbología poética nacional ......53

2.3. Los paisajes azucareros en la novela antiesclavista decimonónica: espacios racializados poblados de monstruos a las márgenes de la nación

2.4. Los paisajes intermedios de la sacarocracia: entre las cañas, las palmas, los esclavos y las máquinas

3. AZÚCAR AGRIDULCE: DISCURSOS AZUCAREROS HEREDADOS Y EL TRIUNFO DE LA REVOLUCIÓN

3.1. De Los ingenios a la antiepopeya azucarera y nacionalista: la caña de azúcar entre la melancolía y la épica nacional

3.2. El azúcar en la Revolución: la reescritura de la Historia y el héroe azucarero en el metarrelato revolucionario y la mirada diferente

3.3. El central y Arturo la estrella más brillante: la contra-memoria azucarera en la obra de Reinaldo Arenas

3.4. La memoria azucarera desde las márgenes: la producción cultural antihegemónica ante la debacle azucarera

CONCLUSIONES .175

BIBLIOGRAFÍA 180

VITA 195 


\section{LIST OF ABBREVIATIONS}

AZCUBA Grupo Azucarero AZCUBA

CAI Complejo Agroindustrial

CAME Consejo de Ayuda Mutua Económica

COI Compañía de Obras e Infraestructura (de Brasil)

ICAIC Instituto Cubano de Arte e Industria Cinematográficos

INRI Instituto Superior de Relaciones Internacionales

MINAZ Ministerio del Azúcar

MINCULT Ministerio de Cultura

TAR Tarea Álvaro Reynoso

UNEAC Unión Nacional de Escritores y Artistas Cubanos

URSS Unión de Repúblicas Socialistas Soviéticas

USDA United States Department of Agriculture 


\section{INTRODUCCIÓN}

Las deplorables condiciones en las que se encuentra ahora la agroindustria azucarera cubana, reducida a una tercera parte de lo que fueran sus centrales y produciendo, anualmente, algo menos de dos millones de toneladas de azúcar — desde que se iniciara su reestructuración en el año 2002-, ha creado una urgencia por representar el impacto que este acontecimiento ha tenido en la sociedad. Más allá de esta urgencia, y también porque sin ella es imposible precisar la envergadura de este evento, también ha surgido la necesidad de rescatar el papel que el azúcar ha jugado en la Historia, la identidad y la cultura cubana. El presente estudio, además de examinar varias de las obras que se produjeron en respuesta a la reestructuración, también intenta responder a esa segunda necesidad, reflexionando acerca de la presencia del azúcar en Cuba, a través del análisis de un corpus heterogéneo unificado por "el motivo del azúcar”.

En este sentido, este trabajo se puede leer como la continuidad $y$ complementación de otras obras dedicadas a la presencia del azúcar en Cuba, aunque, a diferencia de mi estudio, por ser obras anteriores a la reestructuración no contemplan un análisis acerca de este acontecimiento. Contrapunteo cubano (1940) de Fernando Ortiz, El ingenio (1978) de Manuel Moreno Fraginals, “Azúcar, poder y literatura” (1988) y La isla que se repite (2010) de Antonio Benítez Rojo ${ }^{1}$, son algunos de los estudios principales $-\mathrm{y}$ fundadores - que han sido imprescindibles para entender el papel, arbitrario, trascendental y totalizante, que ha jugado el azúcar en la nación. Es de estas

\footnotetext{
${ }^{1}$ Aunque los trabajos de Fernando Ortiz y Manuel Moreno Fraginals son textos que han sido imprescindibles para esta investigación, mi estudio se asemeja más a la obra de Antonio Benítez Rojo, en cuanto a que se concentra mayormente en el análisis de obras pertenecientes a la producción cultural cubana relacionada al azúcar.
} 
obras también, en cierta medida, de donde parte esta investigación y es a ellas a quienes pretende adscribirse.

Siendo la reestructuración azucarera el evento que ha creado esta necesidad de recurrir a la presencia del azúcar en Cuba, en este estudio trazo un mapa histórico cronológico circular (una especie de arqueología del azúcar cubana), que comienza con el análisis de varios textos oficialistas, donde se expone la versión del Estado acerca de este acontecimiento, y cierra con el examen de obras anti-hegemónicas que se apartan del discurso oficial para representar un versión alternativa de los hechos. Entre el análisis de estas dos visiones también realizo un recorrido panorámico que atraviesa la historiografía del azúcar en Cuba desde finales del siglo XVIII hasta la década de los años setenta del XX. Esta revisión me permite fijar la importancia que la industria azucarera ha tenido en la historia de la nación, de modo especial en su identidad y su cultura, y la existencia, desde los inicios de la expansión azucarera, de dos discursos antagónicos en torno al azúcar: el de la plantación azucarera y el de resistencia anti-azúcar, rótulos con los que Benítez Rojo $(1988,2010)$ ha definido estas dos posturas.

Además de esta visión panorámica, la ecléctica naturaleza del corpus escogido discursos, artículos y notas de prensa, poemas, novelas, cuentos, grabados, documentales, largometrajes y fotografías, entre otros - también me permite destacar la casi omnipresencia del azúcar en la nación. Aunque los principales estudios acerca de esta gramínea se han concentrado, mayormente, en el análisis de textos jurídicos, económicos, históricos y literarios, otras disciplinas o géneros han estado igualmente permeadas por los discursos azucareros. La selección de este corpus, a pesar de que reconoce sus límites — dada la imposibilidad de abarcar en un estudio de esta naturaleza todos los textos 
azucareros - sí aspira a proyectar una visión relativamente abarcadora del tema. Gracias a su diversidad genérica se produce un diálogo intertextual —entre todos los textos- que manifiesta todas las contradicciones y matices que emanan de la ubicuidad del motivo. Asimismo, al sistematizar estas obras, colocándolas en un corpus concreto y, sobre todo, en un marco contextual e histórico amplio e integral, se establece una base referencial común que facilita y enriquece el análisis y la interpretación.

La oposición entre los dos discursos azucareros, que convierte al azúcar en un símbolo bifronte — por excelencia agridulce — de la nación, constituye en este estudio el hilo conductor. A través de conceptos relacionados al discurso, al paisaje, al proceso constructivo de la nación, a la historia y a la memoria, en los capítulos a continuación exploro la presencia del azúcar en la Isla: de qué manera influenció la visión de la nación cubana; cómo fue representada dentro de los paisajes nacionales; qué relación tuvo con la africanización e industrialización del país; cómo se ha insertado el capítulo azucarero dentro de la Historia, o las historias cubanas; qué variaciones, con el devenir histórico, han sufrido sus discursos y de qué diversas maneras son evocados por la memoria eventos relacionados al azúcar que marcaron a la nación y a sus individuos, son algunas de las preguntas principales que intento responder en este estudio.

En el primer capítulo, que inicia con la reestructuración, analizo algunos de los textos fundamentales a través de los cuales el régimen le comunicó a las trabajadores azucareros el cierre y desmantelamiento de gran parte de los centrales de la Isla. También incluyo el examen de varios artículos y notas de prensa que fueron emitidos durante estos años donde se reproduce la versión oficial de este evento. El estudio de estos textos me permite explorar la retórica que se ha utilizado para narrar la reestructuración, con el 
propósito de definir hasta qué punto el discurso oficial, cubre, en su totalidad, los negativos efectos de este acontecimiento, incluyendo el trauma humano.

En el segundo acápite de este capítulo inicial, analizo un conjunto de ponencias presentadas en un seminario en torno a la cultura del azúcar en la nación, evento que fuera convocado a raíz de la reestructuración azucarera. El examen de estos textos también intenta definir si estos espacios que se crearon fueron suficientes a la hora de documentar el verdadero impacto de la reestructuración, teniendo en cuenta que este seminario fue organizado por una institución cultural oficial y que sus participantes, en mayor o menor medida, están comprometidos con las políticas culturales del Estado.

El segundo capítulo de este estudio comprende un recorrido panorámico que examina la presencia del azúcar en Cuba durante la era colonial. En el primer apartado analizo un conjunto de textos de naturaleza jurídico-económica representativos de los dos discursos azucareros. Esta lectura está enfocada en definir de qué manera ambos discursos influenciaron la concepción de la nación y la representación del azúcar y del negro en el imaginario nacional y, posteriormente, en la literatura de la época.

En el segundo y tercer acápite de este capítulo me enfoco en el paisajismo literario, que durante esta época pretende definir y fijar lo propiamente cubano. Primero examino un conjunto de poemas con el fin de determinar el papel que el azúcar $-\mathrm{y}$ en general los paisajes azucareros - juegan dentro de la simbología poética nacional. Después recurro a la narrativa antiesclavista decimonónica para definir la diferencia representacional, si es que existe, entre los paisajes naturales - depositorios de lo cubano- y los paisajes azucareros. Por otra parte, en estos acápites también exploro cómo el temor al negro y la aversión que sintieron los románticos hacia la 
industrialización terminaron influenciando la percepción del paisaje azucarero.

En el último apartado de este capítulo me enfoco nuevamente en la representación de los paisajes azucareros dentro del paisaje nacional, aunque el texto escogido, a diferencia de las obras analizadas en los acápites anteriores, es representativo del discurso de la plantación. Uno de los objetivos de este análisis es definir las diferentes maneras en que los paisajes azucareros —incluyendo el cuerpo negro y la máquina— son percibidos y representados en dependencia del discurso azucarero al que la obra se adscriba.

En el primer acápite del tercer capítulo, que comprende textos de la era republicana, regreso a la literatura anti-azúcar con el fin de analizar las variaciones que puede haber sufrido este discurso, a raíz de los cambios que se produjeron en la agroindustria azucarera desde finales del siglo XIX. La abolición de la esclavitud, las Guerras de Independencia, el resurgimiento del colonato, el papel que Estados Unidos comenzó a jugar dentro de la industria azucarera cubana, son algunos de los acontecimientos que aquí investigo y que terminan permeando la literatura de la época. En este análisis también exploro cómo estos eventos influenciaron la percepción y representación del paisaje azucarero dentro del imaginario nacional.

En el segundo apartado de este capítulo, ya en la era revolucionaria, examino algunas obras, creadas desde la oficialidad, con el fin de entender cómo el nuevo poder se apropia $-\mathrm{y}$ reinterpreta — los discursos azucareros heredados. A través de este análisis distingo en qué medida la ideología y las políticas económicas del régimen permearon el discurso azucarero e influenciaron la percepción y la representación del azúcar —como símbolo nacional y de la Revolución — y la del trabajador azucarero. También exploro la manera en que el discurso oficial reescribe la historia azucarera de la nación y la inserta 
dentro del metarrelato revolucionario. Para finalizar este apartado, analizo algunas obras que, a pesar de haber sido producidas desde instituciones oficiales, se alejan del discurso del poder, al concentrarse, mayormente, en elementos de la cultura azucarera. Dentro de estas obras también se puede percibir una postura de resistencia que critica y desmantela el discurso azucarero del régimen.

En el tercer acápite de este último capítulo analizo obras que narran algunos acontecimientos ocurridos dentro de la Revolución, pero que fueron excluidos de la Historia azucarera revolucionaria. Uno de los aspectos que más me interesa explorar en este apartado es la manera en que estas obras deconstruyen la resignificación del azúcar por parte de la ideología revolucionaria, como símbolo legitimador de la Revolución. También me interesa destacar los efectos que la ideología y las políticas azucareras del Estado habían tenido en la psicología de la nación, su repercusión directa en la psiquis de los individuos.

En el último apartado examino la producción cultural anti-hegemónica que surgió en respuesta de la debacle azucarera. El análisis de este corpus variopinto — conformado por fotografías, grabados, literatura testimonial, cine documental y de ficción, entre otros- es un ejercicio dialógico que interactúa con los textos presentados en el primer capítulo, donde analizaba la retórica del discurso oficial en torno a la reestructuración y cuestionaba si ese discurso creaba espacios catárticos donde exorcizar el trauma azucarero sufrido por la población. La lectura de estas obras intenta definir las diferencias entre ambos discursos o versiones acerca de la debacle, el oficial y el anti-hegemónico, y explora las diversas maneras en que estas obras alternativas evocan el azúcar como motivo fundamental, esencial, de la identidad y la cultura cubana. 
Este estudio que, como antes dije, se nutre de obras clásicas, imprescindibles, que exploran la presencia del azúcar en Cuba — fundamentalmente, los textos de Fernando Ortiz, Manuel Moreno Fraginals y Antonio Benítez Rojo-, busca expandir y complementar esos trabajos por tres vías fundamentales. En primer lugar, mi estudio contempla el papel del azúcar en todos los períodos históricos, desde la expansión de la industria a finales del siglo XVIII hasta el presente, y lo hace a través de un corpus heterogéneo que rebasa el ámbito literario ${ }^{2}$. En segundo lugar, este estudio presenta un análisis de la apropiación de los discursos azucareros dentro de la Revolución y explora cómo estos discursos fueron representados por la producción cultural oficial ${ }^{3}$. Por último, mi estudio identifica y discute un corpus reciente, surgido a consecuencia de la debacle azucarera, en el amplio marco histórico referencial del devenir del azúcar como símbolo de la nación cubana, para poner de relieve el papel fundamental de esas obras como espacio representativo de los efectos traumáticos de la reestructuración.

\footnotetext{
${ }^{2}$ A diferencia de las obras de Benítez Rojo, que se concentran mayormente en el análisis de lo que se pudiera definir como la literatura del azúcar cubana, en este trabajo también incluyo el estudio de obras relacionadas al azúcar de naturaleza no literaria, como son el cine documental y de ficción, la fotografía, entre otros.

${ }^{3}$ En "Sugar and Revolution (A Requiem)", conferencia auspiciada por el Cuban Research Institute de Florida International University en el año 2013, Duanel Díaz Infante también examina la apropiación y representación de los discursos azucareros por parte del régimen revolucionario. Su estudio, a diferencia del mío, además de ser menos abarcador (se concentra mayormente en la era republicana y en las primeras décadas de la Revolución), se limita a textos literarios. Esta conferencia fue publicada en Diario de Cuba bajo su título en español.
} 


\title{
CAPÍTULO 1
}

\section{LA REESTRUCTURACIÓN AZUCARERA DENTRO DEL DISCURSO HISTÓRICO}

\section{REVOLUCIONARIO: CÓMO SE PERCIBE EL PROCESO}

\author{
SEGÚN EL DISCURSO OFICIAL
}

Las personas les cuentan a los niños las historias del central ... se han encargado de contarles todo lo que había aqui: dónde estaba la fábrica, dónde el basculador. . . De eso es de lo único que se les puede hablar, porque ya no hay referencias. -Gladys Abreu Cárdenas ${ }^{4}$

\subsection{LOS TEXTOS Y LA PRENSA OFICIALISTAS: LA VERSIÓN MONUMENTAL}

\section{Y TRIUNFALISTA DE LA REESTRUCTURACIÓN}

El 21 de octubre de 2002, como parte del acto inaugural de los Cursos de Superación para Trabajadores Azucareros, Fidel Castro pronunció un discurso donde ratificaba la decisión del gobierno de poner en marcha un plan de reestructuración de la agroindustria azucarera. Dicho plan, bajo el nombre Tarea Álvaro Reynoso (TAR) ${ }^{5}$, ya se había estado realizando desde abril de ese mismo año. Como consecuencia se cerraron 70 centrales azucareros de los $156^{6}$ existentes. 61 de ellos fueron, además, desmantelados, quedando, según Castro, alrededor de 58.000 o 60.000 trabajadores excedentes ${ }^{7}-$

\footnotetext{
${ }^{4}$ Testimonio recogido en La callada molienda (2013), página 184.

${ }^{5}$ Además del cierre de los centrales azucareros, la Tarea Álvaro Reynoso (TAR) estipulaba una reducción sustancial del área dedicada al cultivo de la caña de azúcar, entre otros cambios (J. Álvarez 2004, González-Corzo 2015).

${ }^{6}$ En el discurso Fidel Castro plantea que se cerraron 70 centrales, de los 155 existentes, aunque en realidad eran 156 la cantidad total de centrales. Para una lista detallada con el nombre y destino de los centrales puede consultar "The Current Restructuring of Cuba Sugar's Agroindustry" (J. Álvarez 2004).

${ }^{7}$ Según Carmelo Mesa-Lago alrededor de 219.600 trabajadores fueron afectados en el año 2002 por el cierre de los centrales y las plantaciones cañeras ("Problemas sociales y económicos en Cuba durante la crisis y la recuperación" [2005]). Philip Peters, por su parte, menciona un estimado de 213.000 (Cutting Losses: Cuba Downsizes its Sugar Industry [2003]). En todo caso, además de que ambas cifras se asemejan, son muy superiores a las que manejara Castro en el discurso.
} 
eufemismo que utilizó durante todo el discurso para evitar reconocer la cantidad de trabajadores desplazados o desempleados que dejaba la reestructuración.

Empleando un tono eminentemente esperanzador y paternalista, donde no sólo se retomaban episodios históricos que durante décadas habían legitimado a la Revolución y se ensalzaban algunas de las glorias revolucionarias apelando a un nacionalismo extremo $^{8}$, sino que también se descontextualizaba constantemente la realidad para minimizar el catastrófico efecto de la decisión, Castro explicaba la necesidad de reestructurar la industria y comentaba las medidas que el gobierno tomaría como solución. La primera disposición - y quizás la única para la mayoría - era la oportunidad que se les ofrecía a los trabajadores afectados de continuar sus estudios matriculándose en cursos de capacitación, o incluso carreras universitarias para los que tuvieran la preparación adecuada. En el discurso se afirmaba que con esta medida " primera vez se pon[ía] en práctica el concepto del estudio como empleo" (1), algo que según Castro, se convertiría en uno de los empleos más importante del país ${ }^{10}$. Este enfoque evidenciaba que el gobierno no tenía la capacidad, ni la intención, de volver a emplear a los zafreros en el sector estatal en un futuro cercano, por lo que sólo un

\footnotetext{
${ }^{8}$ En uno de los últimos párrafos del discurso se lee: “¿Algunos de ustedes se imagina que podríamos abordar problemas de esta índole en estos momentos . . . sin esta unidad de un pueblo . . . que ha sido capaz ya de escribir la proeza que no habría escrito otro país? Es difícil resistir 43 años de bloqueo y haber hecho lo que ha hecho en 10 años de período especial. Va llegando la hora de cosechar los frutos" (21). Pasajes similares abundan en todo el discurso.

${ }^{9}$ Para más información de cómo el Estado concebía esta medida dentro de la reestructuración azucarera, se puede remitir a "Programa para la incorporación al estudio de 100 mil trabajadores del MINAZ", documento emitido por el Ministerio del Azúcar en el año 2002, recopilado por Maylán Álvarez en $L a$ callada molienda (2013).

${ }^{10}$ Según Mesa-Lago, 44.000 trabajadores azucareros despedidos a raíz de la reestructuración estaban estudiando y recibiendo un salario bajo este concepto de "estudio como empleo". Otros 20.000 estudiaban carreras de educación superior y 8.500 se encontraban tomando cursos de 10 meses en trabajo social y tendrían garantizados en el futuro un empleo o el ingreso a carreras humanísticas universitarias ("Problemas sociales y económicos en Cuba durante la crisis y la recuperación” [2005]).
} 
porcentaje menor podría beneficiarse de la segunda disposición, la cual garantizaba a algunos la reincorporación al trabajo en otras áreas de la agricultura u otras ramas desvinculadas totalmente de la labor agrícola, como era la educación ${ }^{11}$.

Según Castro, y en parte debido a estas medidas, lo que en el capitalismo constituía una tragedia, porque cientos de miles de personas quedaban desempleadas si se cerraba cierta cantidad de centrales azucareros, en Cuba no presuponía ningún evento traumático.

En nuestro país [decía] no ha sido una tragedia tener 50 centrales sin funcionar en el año 2002. Ningún trabajador quedó sin protección, sus ingresos, no le faltó nada. Nuestro estado socialista podía parar 45 centrales, sin que se enterara nadie; al contrario, en los centrales azucareros mejoraron muchas cosas, han ido construyendo viviendas, han ido mejorando la alimentación de los trabajadores, han ido haciendo hasta actividades de tipo cultural, han ido organizando, han ido creando una estructura de producción de caña en condiciones que favorecen esta tarea. (16)

Con tales palabras, se hacía evidente que dentro del discurso de la oficialidad no habría cabida para narrar el devastador impacto que el cierre de los centrales azucareros tendría en las comunidades cuyas vidas giraban en torno a la producción del azúcar. Castro impedía toda posibilidad de expresar el descontento y el vacío que este evento creaba y terminaba su discurso con un cierre que exhortaba a la resistencia, al mismo tiempo que resultaba lapidario: "No tengo más nada que añadir, y concluyo con la seguridad de que más que nunca cada patriota y cada revolucionario cubano, que ya es un título honorífico

\footnotetext{
${ }^{11}$ Según el testimonio de Gladys Abreu Cárdenas, ex-directora de la sede del Ministerio del Azúcar (MINAZ) en el central Puerto Rico Libre (antiguo Conchita) en la provincia de Matanzas, muchos dirigentes del MINAZ, aunque no eran oficialmente educadores, asumieron el papel de instructores en los cursos de capacitación de los trabajadores azucareros, para no quedarse sin empleo (M. Álvarez 180-181). También está el caso de Mayra Díaz, ingeniera mecánica del central José Smith Comás (antiguo Progreso) en Matanzas, a quién conocí durante mi visita al sitio en julio de 2016. El central lo habían cerrado y convertido en un museo del azúcar y a Mayra le habían ofrecido que se quedara desempeñando el papel de museóloga.
} 
grandioso [énfasis añadido] cumplirá con su deber. ¡Viva el socialismo! ¡Patria muerte! ¡Venceremos!” (21).

Ya desde mayo de ese mismo año, como prueba de que la cúpula gubernamental, a diferencia de lo que expresara Castro en el discurso, estaba consciente de la envergadura de tal decisión — de la conmoción que produciría — e incluso temerosa ante la reacción de las comunidades afectadas, se habían estado realizando un sinnúmero de asambleas ${ }^{12}$ donde se les explicaba detalladamente a los trabajadores en qué consistía la restructuración de la industria azucarera y el impacto, que según el gobierno, presupondría.

Para estos eventos el Ministerio del Azúcar (MINAZ) preparó unos textos, entre ellos el Documento Programático, que servían como guía y base. El Documento, que según la periodista Maylán Álvarez era leído en cada asamblea (28), seguía el mismo orden del discurso de Castro. En los párrafos iniciales apelaba a la historia de la caña de azúcar en la nación, enfatizando la cara oscura de la industria azucarera durante el período colonial y republicano. El trabajo esclavo que sustentaba la industria; los grandes latifundios, en su mayoría en manos de compañías norteamericanas; el tiempo muerto, el desempleo y el desalojo campesino; entre otros, eran rememorados, una y otra vez, para luego ser contrastados con los cambios positivos que había introducido la Revolución: la Primera Ley de Reforma Agraria ${ }^{13}$; la nacionalización de los centrales azucareros ${ }^{14}$; los

\footnotetext{
${ }^{12}$ Según información emitida por el MINAZ, recopilada por el periodista Juan Varela Pérez y publicada en Granma el 20 de diciembre del 2002, se realizaron 7.850 asambleas donde participaron un total de 942.452 trabajadores. Copia de esta publicación se puede consultar en La callada molienda (M. Álvarez 2013).

${ }^{13}$ La Primera Ley de Reforma Agraria fue promulgada el 17 de mayo de 1959 y publicada en la Gaceta Oficial de la República de Cuba el 3 de junio del mismo año.
} 
convenios favorables ${ }^{15}$ con la Unión de Repúblicas Socialistas Soviéticas (URSS) y demás países socialistas del Consejo de Ayuda Mutua Económica (CAME) y la producción, durante la etapa revolucionaria, de más de 6 millones de toneladas de caña de azúcar en 23 zafras. Después de hacer este recorrido, el documento introducía la necesidad de la reestructuración y explicaba sus pautas, no sin antes exponer la poca rentabilidad de la industria azucarera debido al alto costo de producción del azúcar y a su bajo precio de venta en el mercado mundial. Por último, anunciaba las medidas que el gobierno tomaría para garantizar el bienestar de los trabajadores afectados, enfatizando que en los países capitalistas que encaraban crisis similares en la agroindustria cañera, los trabajadores sufrían las consecuencias, quedando en un total desamparo.

El Documento Programático, al igual que el discurso, constataba la imposibilidad de que los trabajadores azucareros participaran activamente en el proceso de decisión que definiría, no sólo el futuro de la agroindustria azucarera, sino el de sus vidas y las de sus familiares. La oficialidad había creado un discurso que vislumbraba una única alternativa para la industria: su reducción, y una única reacción ante este evento por parte de los trabajadores: acatar las medidas obedientemente, ahogando en silencio su descontento en favor de la Patria. A eso se refería Castro cuando decía que confiaba en que los patriotas y revolucionarios cumplirían con su deber.

Durante los años siguientes, y a pesar de las transformaciones que se empezaron a

\footnotetext{
${ }^{14}$ Bajo la Ley No. 851 del 6 de julio de 1960, publicada en la Gaceta Oficial de la República de Cuba el 7 de julio del mismo año, fueron expropiadas forzosamente las propiedades norteamericanas en Cuba, incluyendo 36 centrales azucareros.

${ }^{15}$ Estos convenios garantizaban un precio preferencial al azúcar cubana y un bajo costo del petróleo soviético, entre otros términos excesivamente generosos que beneficiaban a Cuba. Para mayor información sobre las relaciones económicas entre Cuba y el CAME y el impacto que tuvo para la economía de la Isla la caída del Bloque del Este puede consultar Cuba After the Cold War (1993), editado por Carmelo MesaLago.
} 
implementar a través de la Tarea Álvaro Reynoso, la situación de la industria azucarera continuó en detrimento. Si en el año 2002 Castro mencionaba que no se habían logrado producir los 4 millones planificados, en la zafra del 2009-2010, la más baja en 105 años $^{16}$, sólo se produjeron 1.16 millones. A raíz de este hecho Cuba anunció el cierre del emblemático Ministerio del Azúcar. El 28 de octubre del 2011, nueve años después de haber sido iniciada la reestructuración, era firmado por el ahora Presidente del Consejo de Estado de la República, Raúl Castro, el Decreto-Ley No. 287, donde se extinguía el Ministerio del Azúcar como Organismo de la Administración Central del Estado. Al día siguiente se legalizaba el Decreto No. 294 que estipulaba la creación del Grupo Azucarero (AZCUBA) $)^{17}$, una entidad empresarial que a partir de ese momento se encargaría de la agroindustria azucarera.

A pesar de los nuevos cambios la producción azucarera en Cuba ha seguido siendo muy baja. En las tres últimas zafras se produjeron menos de dos millones de toneladas ${ }^{18}$ y AZCUBA, aunque continúa aspirando a elevar el rendimiento a 28 millones para los próximos años ${ }^{19}$-meta que hasta la fecha parece inalcanzable—, sigue

\footnotetext{
${ }^{16}$ En un artículo publicado en Granma el 5 de mayo de 2010, el periodista Juan Varela Pérez reconocía que "desde 1905 el país no registraba una zafra tan pobre".

${ }^{17}$ Información detallada sobre las responsabilidades y funciones del Grupo Azucarero AZCUBA se puede encontrar en "AZCUBA: un nuevo modelo de la agroindustria cañera cubana" (2015) de Federico Sulroca Domínguez.

${ }^{18}$ Las notas de prensa relacionadas a los reportes de la zafra emitidas por el periódico Granma, órgano oficial del Estado, se limitan a hablar sobre incumplimientos o aumentos de la producción, pero no develan con exactitud cuantos millones de azúcar se producen cada año. Según un reporte del Departamento de Agricultura de los Estados Unidos (USDA) en las cuatro últimas zafras (2015, 2016, 2017 y 2018) Cuba produjo $1.8 ; 1.6 ; 1.8$ y 2.0 millones de toneladas de azúcar respectivamente.

${ }^{19}$ En su estudio "La inserción de la agroindustria cañera cubana en la economía internacional" (2015), Lázaro Peña Castellanos plantea que AZCUBA pretende producir 28 millones de toneladas de azúcar a corto plazo.
} 
incumpliendo su plan de producción actual ${ }^{20}$. Por otra parte, de los 71 centrales que originalmente quedaron abiertos, sólo unos 50 han estado activos en las recientes zafras. La incertidumbre, lejos de disiparse, ha seguido acechando a los trabajadores de este sector, quienes ya llevan casi dos décadas siendo víctimas de la reestructuración.

Aunque un evento de tal magnitud (el cierre de aproximadamente el $75 \%$ de los centrales azucareros y alrededor de 219.000 trabajadores desplazados ${ }^{21}$ ) ha provocado consecuencias nefastas para los habitantes de los bateyes, los medios de comunicación controlados por la oficialidad - han reproducido a través del quindenio la retórica descontextualizadora y triunfalista del régimen, silenciando el sufrimiento de los zafreros y sus familiares. En varios artículos de prensa publicados durante los últimos años en Granma —órgano oficial del Partido Comunista—, sus creadores han retomado la estrategia de acudir al pasado oscuro del azúcar para legitimar la Revolución, difuminando, de cierta manera, el devastador impacto que la reestructuración gubernamental de la agroindustria azucarera ha causado en la sociedad. Mantener la memoria viva de ciertos eventos históricos para facilitar la justificación y la aceptación de tal medida — una especie de memorización forzada por parte del poder apelando al deber de la memoria de la colectividad, en palabras de $\operatorname{Ricouer}^{22}$ - , ha sido una de las misiones que el gobierno ha realizado, aunque no haya aparecido esto estipulado en ninguno de los documentos públicos emitidos por el MINAZ concernientes a la Tarea

\footnotetext{
${ }^{20}$ Sobre el incumplimiento de los planes azucareros de AZCUBA puede leer los siguientes reportes de prensa emitidos en Granma: "Economía cubana creció un 4\%", publicado el 20 de diciembre de 2015, "A mal tiempo... cambiarle la cara a la zafra", del 5 de julio de 2016 y "Termina la zafra azucarera y crece un 20\%”, del 30 de mayo de 2017.

${ }^{21}$ Ver nota 7.

22 "La memoria ejercida: usos y abusos" en La memoria, la historia, el olvido (Paul Ricoeur 2013).
} 
Álvaro Reynoso, o posteriormente por su sustituto, el grupo empresarial AZCUBA.

En un artículo publicado el 4 de noviembre de $2015^{23}$ se desempolvaba la sublevación de esclavos ocurrida en el año 1843 en el Ingenio Triunvirato ${ }^{24}$, en la actual provincia de Matanzas. El escrito comenzaba con la consabida alusión al régimen esclavista —al sufrimiento esclavo en las plantaciones azucareras-, para luego narrar brevemente los sucesos que ocurrieron durante la rebelión, vinculándolos después a la política guerrerista del gobierno. Oportunamente se reivindicaba la figura de la negra esclava Carlota ${ }^{25}$, quien fuera líder de la contienda, y se rememoraba que en su homenaje la misión internacionalista de Cuba en Angola ${ }^{26}, 40$ años atrás, llevara su nombre. Para finalizar, el artículo citaba el fragmento de un discurso pronunciado por Fidel Castro en 1974, donde planteaba la necesidad "de erigir [. . .] un monumento a la memoria de aquellos heroicos esclavos [que en su día habían sido] precursores de nuestras revoluciones sociales", y ratificaba la construcción de dicha obra en 1991. No mencionaba el escrito que Matanzas había sido una de las provincias más afectadas por la reestructuración azucarera y que de sus 21 centrales, en el año 2012, apenas cuatro

\footnotetext{
23 "El legado Triunvirato" de Ventura de Jesús.

${ }^{24}$ El Ingenio Triunvirato, localizado en el municipio Limonar de la actual provincia Matanzas, fue declarado junto con otros centros históricos Monumento Nacional de Cuba el 10 de octubre de 1978.

${ }^{25}$ En respuesta a este artículo Félix Bonné Carcasés publicó una nota en Cubanet, titulada "La homofobia alrededor de Carlota", donde acusa a los historiadores oficialistas por falsear la verdad acerca de las motivaciones de esta esclava por liderar la contienda. Aunque la sublevación ya se había planificado, Carlota, según Bonné, adelantó el alzamiento cuando se enteró que su amante Fermina, esclava de un ingenio vecino, había sido castigada y enviada al cepo. Bonné se queja de que tanto los historiadores como la prensa oficialista siempre obvien mencionar la naturaleza homoerótica de la relación entre ambas esclavas.

${ }^{26}$ Referencia a la Operación Carlota, nombre bajo el cual se conoce la intervención militar de Cuba en la Guerra Civil de Angola, conflicto armado que se inició en el año 1975 y concluyó en el 2002.
} 
quedaban abiertos para la molienda ${ }^{27}$.

En otro artículo divulgado unos meses antes ${ }^{28}$ se rememoraba el discurso que pronunciara Fidel Castro, el 6 de agosto de 1960, para anunciar la nacionalización mediante la expropiación forzosa - de las empresas norteamericanas en Cuba, en respuesta a las medidas económicas que el gobierno estadounidense había tomado donde se reducía la cuota cubana de azúcar en el mercado de ese país. Dentro de las empresas que pasaron a ser nacionalizadas ese "histórico día", según el periodista, se incluían 36 centrales azucareros. Algunos de ellos a partir de ese momento, en conmemoración al Primer Congreso Latinoamericano de Juventudes que se estaba celebrando por esas fechas, adoptarían el nombre de una república latinoamericana "como muestra de [. . .] [la] unidad inquebrantable con los pueblos hermanos del continente". El escrito no aclaraba que varios de estos centrales habían sido desmantelados como consecuencia de la reestructuración que se llevara a cabo desde el año 2002, ni que el gobierno cubano había abierto la industria azucarera al capital extranjero a partir de $2012^{29}$, con la firma de un convenio entre el grupo empresarial AZCUBA y la Compañía de Obras e Infraestructura (COI) de Brasil ${ }^{30}$.

Además de la constante revisión historicista donde se explota el pasado oscuro del

\footnotetext{
${ }^{27}$ En la lista elaborada por José Álvarez en el año 2004 (ver nota 6), aparecen 12 centrales desactivados en la provincia de Matanzas. Según el estudio de Maylán Álvarez, sin embargo, en el 2005 otros centrales fueron cerrados y para el 2012, sólo cuatro quedaban abiertos para la molienda.

28 "Cuba dispuso la nacionalización”, artículo de Eugenio Suárez Pérez y Acela Caner Román publicado el 5 de agosto de 2015.

${ }^{29}$ La industria había estado abierta al capital extranjero a partir de 1995, pero no sería hasta el año 2012, con la firma del convenio con COI, que esta nueva estipulación se materializara.

${ }^{30}$ Bajo el nombre de Administración Productiva de Azúcar, AZCUBA firmó un contrato con COI donde se estipula que la compañía brasilera asumirá la dirección del central "5 de septiembre", en la provincia de Cienfuegos, por un período de diez años.
} 
azúcar en la época prerrevolucionaria, apelando a la Historia para alimentar los mitos que se han ido tejiendo durante décadas con el fin de sustentar el carácter teleológico de la Revolución, la retórica triunfalista es otro de los recursos de los que se ha valido el gobierno para distorsionar el pernicioso impacto que la reestructuración azucarera tuvo en la población y el lastimoso estado en el que se encuentra la industria. El 30 de diciembre de 2014 bajo el título "Dulces noticias" 31 se leía: "El cierre del año, siempre cargado de alegría y buenos deseos [énfasis añadido], ha visto también coronarse el esfuerzo de los azucareros cubanos quienes cumplieron sus planes para la zafra chica en el país”. A pesar de que la alentadora noticia auguraba segura una excelente zafra para el cierre del ciclo, los resultados enterraron la certidumbre del desacertado pronóstico: el período, según una nota que se publicó en el propio Granma un año después ${ }^{32}$, cerró con un 5,3\% de déficit del plan previsto para el año. Por esas mismas fechas, sin embargo, la prensa también había estado publicando varios artículos que mencionaban las previsiones que se habían realizado para garantizar una buena molienda: "Zafra: vale mucho iniciar bien" 33, "Preparativos de zafra en Mayabeque" 34, "Alistan los cinco centrales cienfuegueros para el comienzo de la zafra",35, eran algunos de los encabezamientos de escritos alentadores que vaticinaban una exitosa producción.

Para la molienda del año 2015-2016, por su parte, la prensa continuó publicando

\footnotetext{
${ }^{31}$ El artículo, al carecer de nombre de autor, se le atribuye a la Redacción Nacional.

32 "Economía cubana creció un 4\%", artículo de Leticia Martínez Hernández (ver más detalles en la nota 20).

${ }^{33}$ Artículo de Ventura de Jesús García Gutiérrez publicado el 21 de octubre de 2014.

${ }^{34}$ Artículo de Alberto G. Walon publicado el 28 de septiembre de 2014.

${ }^{35}$ Artículo de Julio Martínez Molina publicado el 13 de noviembre de 2014.
} 
artículos optimistas que reiteraban la incongruencia entre el discurso oficial y la realidad de una industria que ha ido pereciendo en los últimos años a pesar de las reformas. "Azucareros no quieren 'casualidades' con la zafra" "36, "Abre Camagüey dos frentes de molienda" ${ }^{37}$, "Continúan preparativos para la próxima zafra azucarera" ${ }^{38}$, rezaban algunos de los títulos de la temporada anunciando las previsiones y pronosticando el éxito de la industria. Lo mismo sucedería con respecto a la pasada zafra (2016-2017); una vez más la prensa oficialista inundaría sus páginas con encabezamientos alentadores: "Zafra cubana puede producir más azúcar"39, "Zafra chica para moler en grande”," "Más centrales incorporados a la zafra en Cuba"41, afirmaban algunos de los enunciados augurando altos rendimientos que al final de la molienda no lograron cumplirse.

Más allá de los escritos relacionados con la producción azucarera la oficialidad también se ha encargado de divulgar noticias concernientes a la llamada reanimación de los bateyes, como parte del Programa de Atención a los Bateyes Azucareros desarrollado inicialmente por el MINAZ en conjunto con el Ministerio de Cultura (MINCULT). Aunque la necesidad de este empeño por parte del gobierno evidencia el lamentable estado en que quedaron estas comunidades debido al cierre de los centrales, una vez más el régimen sólo cuenta una parte de la historia, aquella que legitima el carácter benévolo y paternalista de la Revolución, y oculta el lado oscuro de la reestructuración de la

\footnotetext{
${ }^{36}$ Artículo de Juan Antonio Borrego publicado el 10 de noviembre de 2015.

${ }^{37}$ Artículo de Miguel Febles Hernández publicado el 23 de diciembre de 2015.

${ }^{38}$ Artículo de Leidys María Labrador Herrera publicado el 11 de octubre de 2015.

${ }^{39}$ Artículo de Prensa Latina publicado en Granma el 6 de enero de 2017.

${ }^{40}$ Artículo de Ortelio González Martínez publicado el 23 de diciembre de 2016.

${ }^{41}$ Artículo de Lino Luben publicado el 7 de diciembre de 2016.
} 
agroindustria azucarera. En junio de 2014, el Granma publicaba una nota anunciando la presentación de libros en bateyes de antiguos centrales azucareros cienfuegueros, como parte de una gira de escritores que se estuviera realizando en la provincia ${ }^{42}$. Ninguno de los títulos que se presentaron ${ }^{43}$ estaban relacionados con el azúcar, ni con el impacto social que produjo la reciente reforma de su industria. Unos meses después, en enero del 2015, era el Circo Nacional de Cuba el que hacía noticia ${ }^{44}$, la prensa informaba diversas presentaciones en varios cines de bateyes azucareros como parte de la política de reanimación de dichos sitios.

El acontecimiento que según Castro no constituía ningún suceso traumático, había provocado que el Estado recurriera al Ministerio de Cultura del país para desarrollar eventos culturales en las comunidades afectadas. A pesar de que proyectos de esta naturaleza no eran necesariamente nuevos en estas localidades - ya que el gobierno durante años se había encargado de organizar eventos culturales en los bateyes por constituir estos parte vital de la economía de la nación—, lo peculiar en todo caso es el enorme contraste entre la realidad — centrales desmantelados y pueblos en ruinas- y estos espacios culturales creados desde la oficialidad donde no hay cabida para el dolor y la nostalgia. La cultura de evasión venía a auxiliar al régimen en un momento en que evidentemente los trabajadores azucareros y sus familiares mostraban descontento ante la reestructuración.

\footnotetext{
42 “Presentan libros en bateyes azucareros" de Julio Martínez Molina publicada el 15 de junio de 2014.

${ }^{43}$ Según la nota se presentaron los títulos "Arrorró Melanie", libro de poesía infantil de Lourdes Díaz Canto; "El retorno de Fangoso", literatura fantástico infantil de Enid Vian; "El caballero de la luna", libro para adolecentes de Rebeca Murga y Lorenzo Lunar; "El libro de los sonetos", recopilación de poemas inéditos de Hipérides Zerguera y "A sacris", poemario de Michel Martín.

44 "El Circo Nacional monta su carpa en Cienfuegos" de Julio Martínez Molina publicada el 18 de enero de 2015.
} 
También en conjunto con el desaparecido MINAZ, y a raíz del detrimento de la agroindustria, el MINCULT, junto a otras organizaciones gubernamentales ${ }^{45}$, retomó un programa para la conservación del patrimonio azucarero, encargado, entre otros, de la organización de los Encuentros Nacionales del Patrimonio Histórico Azucarero. Aunque estos encuentros se habían estado desarrollando desde el año 1999, tres años antes de anunciada la reestructuración, en aquel momento, según nota oficial de AZCUBA, "no tendría[n] tanta repercusión, divulgación y participantes como en la actualidad"46. Por otra parte, el programa para la conservación del patrimonio también asumió dentro de sus responsabilidades la transformación de algunos de los antiguos centrales azucareros, ahora desactivados, en los llamados museos del azúcar; un proyecto que, aunque acogido en inicio por personas interesadas en conservar el patrimonio azucarero ${ }^{47}$, hasta la fecha sólo evidencia el empeño estatal por explotar parte de éste como un atractivo turístico.

Los ingenios escogidos para ser convertidos en museos — por ahora sólo cuatro ${ }^{48}$ en toda la Isla - han seguido un principio de selección ${ }^{49}$ basado no sólo en su valor

\footnotetext{
${ }^{45}$ La Comisión de Patrimonio Histórico Azucarero, el Consejo Nacional de Patrimonio Cultural y la Comisión Nacional de Monumentos son instituciones que también están involucradas en el programa de conservación del patrimonio azucarero.

${ }^{46}$ Nota de Tania Azahares, comunicadora institucional del Grupo AZCUBA, sobre el XV Encuentro Nacional del Patrimonio Histórico Azucarero efectuado en la ciudad de Bayamo en noviembre de 2014. La nota fue publicada en la página oficial de AZCUBA (azcuba.cu) el 19 de noviembre de 2014.

${ }^{47}$ Ver nota 50 sobre la intervención de Nilson Acosta en el seminario organizado por la Fundación Fernando Ortiz.

${ }^{48}$ Durante mi viaje a Cuba en julio del 2016, sólo había cuatro ingenios convertidos en museos del azúcar: José Smith Comas (antiguo Progreso) en Cárdenas, Matanzas; Marcelo Salado (antiguo Reforma) en Caibarién, Villa Clara; Patria o Muerte (antiguo Patria) en Morón, Ciego de Ávila y la Federación Nacional de Trabajadores Azucareros o FNTA (antiguo Trinidad) en Trinidad, Santi Spíritus.

${ }^{49}$ Durante su intervención en el seminario convocado por la Fundación Fernando Ortiz sobre la cultura del azúcar (ver nota 55), Francisco Mirayes, entonces asesor del Ministro del Azúcar, explica que los ingenios convertidos en museos "están ubicados cercanos a los polos turísticos, de modo que la inversión para
} 
patrimonial tangible - fundado en la arquitectura de los edificios y la presencia de locomotoras, máquinas y herramientas que datan desde los siglos XVIII y XIX—, sino también en su proximidad a enclaves turísticos. Este criterio de elección, que se justifica en un afán por crear un sistema económicamente sustentable, lejos de mostrar un serio intento por preservar la historia de la industria azucarera en la nación por parte del Estado, o de crear espacios que le den voz a los trabajadores azucareros afectados por la reestructuración, más bien pone al descubierto cuán insensible y engañoso el discurso oficial puede llegar a ser. Excluir el detrimento de la industria y su impacto social e intentar equiparar - $\mathrm{y}$ reducir - la historia del azúcar a un bien de consumo para el turismo extranjero ${ }^{50}$ tiene más de mercancía que de conservación patrimonial.

Más allá de este empeño económico por comercializar la memoria azucarera cubana, el programa para la conservación del patrimonio azucarero, como bien demuestran las notas de prensa oficialistas, también tiene un componente ideológico cuya función es divulgar y perpetuar, de la misma manera que lo han hecho los otros medios de difusión masiva, la versión oficial de los hechos. Tanto la narrativa justificativa concerniente a la reciente restructuración de la industria azucarera, como algunos de los relatos legitimadores de la Revolución, son discursos que prevalecen durante los encuentros nacionales que se realizan anualmente y en las áreas de los ingenios transformados en museos. En un artículo publicado por el grupo empresarial AZCUBA, quien sustituyera en sus labores de conservación patrimonial al MINAZ, se hacía un

prepararlos como museos tenga una recuperación" (92).

${ }^{50}$ En su intervención en el seminario organizado por la Fundación Fernando Ortiz, Nilson Acosta, quien empeñara el cargo de vicepresidente de Monumentos del Consejo Nacional de Patrimonio Cultural, expresa su preocupación ante la posibilidad de que sea el patrimonio azucarero el que responda a las demandas del turismo perdiendo este proyecto su misión original de conservación (77). 
recuento del XV Encuentro Nacional del Patrimonio Histórico Azucarero $(2014)^{51}$. Al inicio de la nota, se destacaba que la inauguración del evento se había realizado en el histórico ingenio de La Demajagua, en la ciudad de Manzanillo, lugar donde el terrateniente azucarero Carlos Manuel de Céspedes había dado la libertad a sus esclavos, iniciando, con este acto, el grito de independencia de la nación. Luego se narraba que los participantes del evento, para homenajear al General de las Cañas —refiriéndose a Jesús Menéndez-, se habían trasladado al lugar donde este dirigente sindical azucarero había sido asesinado en 1948. Por último, y antes de realizar una visita al central azucarero Bartolomé Masó (antiguo Estrada Palma), los concurrentes habían visitado el Museo del Municipio, institución donde se conservan objetos pertenecientes a los guerrilleros que lucharon en la Sierra Maestra. El recorrido físico que realizaran los participantes respondía a un recorrido histórico (cronológico) que es habitual en el discurso oficial, el mismo que realizó Castro cuando anunció la reestructuración de la industria azucarera y el mismo que se recogió en el Documento Programático.

En esta manera particular de recurrir a la historia, donde los grandes acontecimientos y figuras históricas son retomadas y veneradas por el hombre de acción o de gobierno para fortalecerse y reconfortarse — entiéndase la figura de Fidel Castro como máximo líder de la Revolución en este contexto-, se puede reconocer lo que Nietzsche definió como la historia monumental y lo que Foucault, retomando al filósofo alemán, llamó de historia reminiscencia o reconocimiento. Si se analizara el discurso revolucionario desde sus inicios, se concluiría que el uso de la historia monumental definida por Nietzsche ha sido una obsesión del régimen revolucionario. A efectos de este

\footnotetext{
${ }^{51}$ Referencia al artículo de la nota 46.
} 
estudio, los ejemplos expuestos en las páginas anteriores con respecto a la reestructuración de la industria azucarera, bastan para afirmar que el régimen ha acudido constantemente a este modo monumental de apropiación de la Historia para justificar, no sólo las recientes reformas, sino la existencia misma de la Revolución. El discurso histórico del azúcar, como parte del gran relato discursivo revolucionario, ha sido invocado en numerosas ocasiones para demostrar una noción teleológica del proceso histórico cubano, donde la Revolución sería el fin, al ofrecer una forma de vida que solucionaba los violentos conflictos entre las clases sociales. El mito de la revolución inconclusa ${ }^{52}$, que fuera introducido por Fidel Castro bajo la idea de los 100 años de lucha $a^{53}$ y que sería uno de los mitos más frecuentados por el discurso oficial, hunde sus raíces, precisamente, en el pasado cubano del azúcar.

El 10 de octubre de 1968 con motivo del centenario del levantamiento de Carlos Manuel de Céspedes en su ingenio La Demajagua, Castro, en el histórico lugar, pronunció un discurso donde planteó que la Revolución era una, que había comenzado con ese evento histórico, donde el hacendado azucarero liberara a sus esclavos y los exhortara a la lucha, y que todavía se estaba gestando por el pueblo en ese momento. De esa forma se homologaban e insertaban la causa y el proceso revolucionarios a las guerras independentistas de la nación y posteriormente a las luchas de los movimientos sindicalistas del siglo XX. Apoyar a la Revolución - y sus reformas - era de cierta manera volver a participar en aquellas contiendas. Las guerras independentistas,

\footnotetext{
${ }^{52}$ Terminología con la que Rafael Rojas define el mito de los 100 años de lucha (Isla sin fin: contribución a la crítica del nacionalismo cubano [1998]).

${ }^{53}$ Este mito fue magistralmente llevado al llamado cine histórico de finales de la década del sesenta en largometrajes como Lucía (1968), de Humberto Solás, y La primara carga al machete (1969), de Manuel Octavio Gómez.
} 
apropiadas por el discurso oficial, se convertían en un capítulo histórico de la nación cubana que tendría efecto en todas sus épocas. Este modo de representación corresponde con la definición que ofrece Nietzsche acerca de la historia monumental, explicada como una colección de efectos en sí, al presentar los acontecimientos de manera ejemplar y como dignos de imitar, atenuando las diferencias de los motivos y las intenciones, esto es, prescindiendo de las causas (56-57).

Este mismo mito, como prueba de la obsesión monumentalista y la constante necesidad de legitimación de la Revolución, es el que retomó Castro en 1974 cuando planteaba la urgencia de erigir un monumento en el Ingenio Triunvirato, a la memoria de los heroicos esclavos precursores de las luchas revolucionarias, y el mismo que se invocó durante el recorrido que realizaran los participantes del XV Encuentro Nacional del Patrimonio Histórico Azucarero. Aunque a raíz de la reestructuración no ha sido evocada la Historia para justificar nuevas guerras, sino más bien reformas arbitrarias con consecuencias ominosas para la economía y la población, sí han sido borrados, como bien advirtiera Nietzsche al criticar el uso monumental de la historia, pedazos fundamentales de ella. El discurso oficial ha omitido y silenciado ${ }^{54}$ aquellos fragmentos que recogen el verdadero impacto que produjo la medida en la vida de los zafreros y sus familiares, porque no tienen cabida dentro de la distorsionada y embellecida versión monumental de la Historia, que en palabras de Nietzsche se acerca a la pura invención poética o a la ficción mítica (57).

En cuanto a la intelectualidad oficialista, en el próximo acápite analizaré

\footnotetext{
${ }^{54}$ Sobre el silenciamiento oficial puede leer el último acápite de este estudio donde analizo la obra $L a$ callada molienda.
} 
brevemente su respuesta ante la reestructuración, teniendo en cuenta hasta qué punto responden o se alejan sus planteamientos del discurso del poder y de qué manera la postura que adoptaron permitió la creación de espacios donde se documentara el verdadero impacto que el cierre y desmantelamiento de los centrales azucareros infligió en las comunidades azucareras.

\subsection{LA INTELECTUALIDAD COMPROMETIDA: EL FUTURO Y LA MEMORIA DEL AZÚCAR ENTRE LA PREOCUPACIÓN REAL Y EL COMPROMISO POLÍTICO}

Los esfuerzos realizados por una parte de la intelectualidad - como fuera el seminario en torno a la cultura del azúcar en la nación, convocado y organizado por la Fundación Fernando Ortiz en el año $2003^{55}$-, aunque alejados en ocasiones de la retórica excesivamente triunfalista que prevalece en los medios de difusión masiva, todavía son insuficientes a la hora de documentar el verdadero impacto que la reestructuración causó en la población. Al consultar algunas de las ponencias e intervenciones que tuvieron lugar en este evento — las que pasaron a conformar dos años más tarde el número de la revista Catauro $^{56}$ dedicado al azúcar-, es evidente que los conferencistas publicados responden, en mayor o menor medida, a lo que el escritor húngaro Miklós Haraszti, en La prisión de terciopelo (1986), denominó como intelectualidad domesticada ${ }^{57}$. Según Haraszti, en los estados socialistas totalitarios había

\footnotetext{
${ }^{55}$ Este seminario se tituló "La cultura del azúcar en Cuba" y tuvo lugar en la biblioteca pública Rubén Martínez Villena de la Habana Vieja, el 30 de mayo de 2003.

56 “El maestro del azúcar”, Catauro Revista Antropológica Cubana, No. 11, 2005.

${ }^{57}$ Tanto Emilio J. Gallardo en El martillo y el espejo (233-234) como Roger Reed en The Cultural Revolution in Cuba (cit. en Gallardo), hacen referencia a este concepto de Miklós Haraszti al referirse a la
} 
nacido una nueva cultura estética donde los censores y los artistas se fundían en un abrazo. Era a una especie de pacto que se suscitaba entre el estado y la comunidad artística, donde esta última, con su ayuda y complicidad, asistía al primero en su esfuerzo por controlar la cultura. A raíz de esta unión, surgía un arte carente de autonomía que en ocasiones, incluso, podía llegar a ejercer una crítica de línea blanda, permitida, ahora, por el propio estado (5-10).

No es difícil de imaginar que esta intelectualidad, comprometida con la oficialidad, vaya a crear un producto cultural que responda y perpetúe el discurso oficial. Incluso, en su vertiente más crítica, no se pudiera hablar todavía de una verdadera manifestación anti-hegemónica. En todo caso se trata de una forma diferente de concebir el discurso del poder, que, aunque coquetea con la crítica, sigue ejerciendo mecanismos de exclusión para suprimir ciertos temas y posturas disidentes dentro de la cultura. Es, ante todo, una estrategia que adopta el estado para evitar ser juzgado como aparato censor, con la cual, eficazmente, se institucionaliza la crítica.

En la nota editorial del número de Catauro dedicado al azúcar se especifica que en el seminario se trataron dos cuestiones fundamentales sobre el asunto: un primer panel dedicado a la historia del azúcar en la nación y un segundo panel donde se abordaría la situación actual de la industria. Aunque en esta nota inicial se señalaba que en el evento se había "reflexion[ado] sobre los cambios que se esta[ban] sucediendo en la mentalidad individual y grupal de aquellas personas que ha[bían] dependido de esta producción [azucarera] durante toda su vida" (4) y se leían términos como problemática social y trauma, en realidad, la mayoría de los artículos reunidos en esta edición tienen mucho 
más de Historia monumental — justificativa — que de experiencias traumáticas.

La intervención de Miguel Barnet ${ }^{58}$, por ejemplo, que encabeza la publicación y pudiera tomarse como el discurso rector de este evento - teniendo en cuenta su posición como presidente de la UNEAC y de la Fundación-, reproduce varios de los mitos que han conformado el relato histórico revolucionario del azúcar. En su ponencia — de la misma manera que ocurre en el discurso que emitiera Fidel Castro a los trabajadores azucareros y en el Documento Programático ${ }^{59}$ - , Barnet inserta este relato, que no es más que la versión oficial de la presencia del azúcar y el desarrollo de su industria en la Isla, al metarrelato teleológico revolucionario. Según él, el azúcar había unificado la nación en un sincretismo racial, cultural y religioso, pero tanto la práctica esclavista en la etapa colonial, como el carácter neocolonial de la era republicana, habían impedido que ésta alcanzara su plena realización; algo que sólo se logró con la llegada de la Revolución.

La moral esclavista primero y la colonial después se impusieron durante más de cinco siglos en nuestra Isla. Y con esos truenos, ¿qué tipo de nación se iba a crear?: la nación que tuvimos hasta que Fidel Castro desembarcó del yate "Granma" en las costas cubanas y dividió la historia de nuestro país. Antes, con la Guerra de Independencia se habían unido los negros y los blancos, los chinos y los mulatos, y todos en un solo abrazo efímero para anunciar lo que sólo más tarde, con el triunfo de la Revolución Socialista, sería la verdadera nación cubana, liberada de prejuicios raciales y en camino a eliminar la lucha de clases. (8)

Con estas palabras se demonizaban el período colonial y republicano para imprimirle a la

\footnotetext{
${ }^{58}$ Miguel Barnet, reconocido escritor y etnógrafo, es uno de los intelectuales más destacados dentro de la Isla. Además de sus méritos intelectuales, su comprometida postura con el proceso revolucionario le ha valido el cargo de presidente de la UNEAC y de la Fundación Fernando Ortiz, entre otros puestos importantes dentro de la política institucional. La ponencia que presentó para este evento se publicó bajo el título "La cultura que generó el mundo del azúcar" (6-15).

${ }^{59}$ Referencia al discurso emitido el 21 de octubre del 2002 como parte del acto inaugural de los Cursos de Superación para Trabajadores Azucareros y al documento que introducía la reestructuración de la agroindustria cañera a los trabajadores, ambos analizados en las primeras páginas de este trabajo.
} 
Revolución un carácter mesiánico dentro de la formación de la nación cubana ${ }^{60}$. La figura de Fidel Castro se alzaba, entonces, como el mesías indiscutible de una nación que, durante las etapas históricas prerrevolucionarias, había permanecido inacabada. El mito de la revolución inconclusa, ligado a la noción de una nación, también inconclusa, hacía su aparición.

Además de este mito, Barnet adopta en su ponencia la actitud condenatoria que ha mantenido el régimen hacia los tratados comerciales que existían entre Cuba y los Estados Unidos ${ }^{61}$, donde se garantizaba la exportación de la mayor parte del azúcar cubana a su vecino del Norte a precios preferenciales, por encima de los del mercado mundial. El azúcar, en palabras de Barnet, "lo que hizo fue crearnos una economía dependiente y enajenante, sobre todo frente a una potencia [refiriéndose a los Estados Unidos] que hasta hoy nos ha oprimido" (13). Esta afirmación coincide con la postura que el entonces nuevo gobierno había tomado, a partir de 1959, al insistir en que los tratados comerciales entre ambos países habían perjudicado la economía cubana porque la habían condenado a la monoproducción y al monocultivo — convirtiéndola en un apéndice azucarero de los Estados Unidos-. El propio Fidel Castro, a apenas tres meses del triunfo revolucionario, había pronunciado un discurso ${ }^{62}$ durante su visita a Estados Unidos, en la ciudad de Nueva York, donde arremetía contra estos acuerdos. La soberanía de la nación, por su parte, también se había visto amenazada, según el régimen, porque

\footnotetext{
${ }^{60}$ Para ahondar en el carácter mesiánico de la Revolución cubana se puede consultar la obra Isla sin fin: contribución a la crítica del nacionalismo cubano (Rojas 1998).

${ }^{61}$ Referencia al Tratado de Reciprocidad Comercial suscrito el 11 de diciembre de 1902 y al Tratado de Reciprocidad Comercial, que sustituyera al primero, firmado el 24 de agosto de 1934.

62 Referencia al discurso pronunciado durante el almuerzo ofrecido por la Asociación Americana de Editores de Periódicos en el Hotel Statler, en la ciudad de Nueva York, el 17 de abril de 1959.
} 
los intereses económicos del gigante en la pequeña isla propiciaban su injerencia en los asuntos socio-políticos de ésta.

Aunque este razonamiento no es necesariamente del todo desacertado ni originario en el discurso revolucionario, ténganse en cuenta que antes de 1959 ya existía un corpus literario antiimperialista, denunciador de la presencia estadounidense en la agroindustria cañera cubana - piénsese, por ejemplo, en obras como Contrapunteo cubano de Fernando Ortiz o Marcos Antilla de Luis Felipe Rodríguez ${ }^{63}$-, en lo que siempre ha fallado el gobierno, y la producción cultural de la intelectualidad que lo representa, es en no admitir claramente que los tratados económicos que firmara Cuba posteriormente con la Unión Soviética y demás países del $\mathrm{CAME}^{64}$ mantuvieron a la Isla en la misma situación de dependencia. La caída del Bloque del Este, a finales de la década de los ochenta, y la actual crisis de la agroindustria cañera claramente evidencian este estado de subordinación económica y sociopolítica del país. El gran amigo del Este, en todo caso, llegó para rescatar a la nación cuando el gobierno de los Estados Unidos decidió reducir, en 1960, la cuota del azúcar estipulada por el tratado — debido a las medidas tomadas por el régimen cubano que afectaron directamente los intereses norteamericanos en la Isla ${ }^{65}$.

\footnotetext{
${ }^{63}$ Además de Contrapunteo cubano del tabaco y el azúcar (1940), ensayo de Fernando Ortiz, o Marcos Antilla: relatos de cañaveral (1932), libro de cuentos de Luis Felipe Rodríguez, este corpus esta integrado por obras de otros autores como Agustín Acosta, Felipe Pichardo Moya y Nicolás Guillén, entre otros. Algunas obras pertenecientes a este corpus literario anti-azúcar con marcado tono antiimperialista serán analizadas en el último capítulo de este estudio.

${ }^{64}$ Aunque Cuba firma convenios comerciales y créditos con la URSS y demás países del CAME a partir de 1960, no es hasta 1968 que logra la inclusión de exportaciones a estos países como acuerdo preferencial y hasta 1972 que queda integrado al CAME, incorporándose oficialmente a la división internacional socialista del trabajo.

${ }^{65}$ La Ley de Reforma Agraria que estipulaba la eliminación de los latifundios afectando directamente a
} 
Esta nuevas relaciones económicas, por su parte, dieron al traste con la inicial postura adoptada por el gobierno revolucionario, donde se pretendía eliminar el protagonismo de la industria azucarera, diversificando la economía. Si de 1959 a 1963 había predominado un discurso económico — e ideológico - anti-azúcar, a favor de la demolición azucarera ${ }^{66}$ en aras de la diversificación agroindustrial y la soberanía discurso del cual ni Jean Paul Sartre, durante su segunda visita a la Isla, pudo escaparse, como bien demuestran sus artículos recogidos en Huracán sobre el azúcar ${ }^{67}$ — a partir de este último año, y debido a los acuerdos firmados con la URSS y el resto de los países socialistas europeos — que garantizaban nuevas cuotas-, Cuba regresa a una estrategia económica que prioriza la producción del dulce, perpetuando su dependencia comercial. El binomio del azúcar y un único comprador, sólo se desplazaba de lugar ${ }^{68}$, mientras que el mito de la diversificación económica del país se desmoronaba.

En cuanto a la autonomía de la gestión política de la nación, el costo de las nuevas

ciudadanos norteamericanos dueños de tierras en la Isla y la nacionalización de dos refinerías petroleras, también norteamericanas, entre otras medidas, propició que en agosto de 1960 el presidente Eisenhower redujera la cuota cubana del azúcar. Más tarde, a partir de enero de 1961, se romperían las relaciones diplomáticas entre ambos países y en 1962, Estados Unidos implementaría el embargo comercial.

${ }^{66}$ Con este término se conoce una política encabezada por Ernesto "Che" Guevara que se llevara a cabo entre 1960 y 1963, donde se desmantelaron un número elevado de caballerías sembradas de caña, lo cual produjo una baja impresionante de la producción azucarera en los años 1962 y 1963 (Sanguinetty 1999).

${ }^{67}$ Bajo este título se recogieron 16 artículos de Jean Paul Sartre, escritos después de su visita a la Cuba en marzo de 1960 y publicados por el periódico francés France-Soir ese mismo año. En ellos Sartre adopta el discurso anti-azúcar que predominaba en la Isla y defiende ardorosamente a la joven Revolución y a sus principales líderes. El título (Huracán sobre el azúcar), deriva de una metáfora que emplea Sartre, donde describe a la Revolución como un huracán que liberará a la Isla esclavizada por la economía del azúcar (44).

${ }^{68}$ Para más información sobre los períodos económicos - e ideológicos - revolucionarios a favor y en contra del predominio del azúcar, puede consultar "La industria" (1999) de Sanguinetty; "Azúcar y Revolución: el sector azucarero de la economía cubana durante los primeros doce años de la Revolución (1959-1970)" (1994) y "La revolución cubana y la economía 1959-2012: los ciclos de política y el ciclo azucarero" (2014) de Santamaría García y Breve historia económica de la Cuba socialista (2007) de MesaLago. 
alianzas económicas no se hizo esperar y muy pronto se vio obligada la Isla a posicionarse dentro del mapa geopolítico internacional, al lado de sus nuevos socios comerciales. Si en diciembre de 1961, con la declaración del carácter marxista-leninista ${ }^{69}$ de la Revolución, ya se había iniciado este proceso, en agosto de 1968 se ratificaba, rotundamente, con el apoyo a la Invasión a Checoslovaquia —ofensiva que realizaran los países pertenecientes al Pacto de Varsovia, encabezados por la Unión Soviética, en respuesta a la Primavera de $\operatorname{Praga}^{70}$ —. Años más tarde, sucedería lo mismo con el envío de tropas cubanas a Angola y a Mozambique ${ }^{71}$, otro de los escenarios de la Guerra Fría donde el gobierno —o más bien sus ciudadanos - tuvo que participar. La idea de una nación libre y soberana, guiada por una revolución socialista que sólo respondía a sus intereses — doblegados éstos al bienestar social de su pueblo-, es uno de los mitos construidos por el régimen que Barnet perpetúa en su ponencia, aún cuando la realidad lo desmiente. La ayuda del Bloque del Este, especialmente de la URSS, supuso un alto coste para el país, precio que se tuvo que pagar no sólo con la sovietización de su economía, sino también de su política e, incluso, de su cultura. La perpetuación de la industria azucarera como principal —y prácticamente único — reglón económico, fue una política que adoptó el gobierno a partir de 1964, que evidentemente también desmanteló el discurso de la soberanía.

\footnotetext{
${ }^{69}$ Aunque en un discurso pronunciado el 16 de abril de 1961 ya Fidel Castro había proclamado el carácter socialista de la Revolución, no es hasta el 22 de diciembre del mismo año que, en otro discurso, definiera de marxista-leninista el proceso revolucionario.

${ }^{70}$ Nombre con el que se conoce el período de liberación política y cultural que se produjo en la antigua Checoslovaquia en 1968. La URSS y demás países del Pacto de Varsovia —excepto Rumania y Albaniadecidieron invadir a Checoslovaquia para derrocar el gobierno de Alexander Dubček y acabar con este proceso de apertura.

${ }^{71}$ Referencias a las guerras civiles de Angola (1975-2002) y Mozambique (1977-1992).
} 
Cabe destacar, que aunque la mayoría de los conferencias siguieron, en mayor o menor medida, la línea discursiva comprometida de Barnet, hubo algunas instancias en que se desmarcaron del discurso oficial para exponer ideas que, por lo general, son excluidas. Oscar Zanetti ${ }^{72}$, por ejemplo, aunque también repasa el lado oscuro del azúcar en las etapas prerrevolucionarias —el tiempo muerto, el latifundio, la economía dependiente, entre otros - y enarbola con entusiasmo el carácter benévolo de la mesiánica Revolución, sorprende al dedicarle un espacio a los avances tecnológicos que existían en la Isla desde finales del siglo XIX y durante las primeras décadas del XX, períodos que, generalmente, son descritos como dañinos para la economía de la nación dentro del discurso hegemónico. "Hay que tener en cuenta que, además, Cuba tuvo las mayores fábricas de azúcar del mundo en la década del veinte del siglo pasado y concentraba también los más destacados avances tanto de la tecnología mecánica como de la química azucarera" (15). Por otra parte, al hablar de las relaciones comerciales con los Estados Unidos, Zanetti tilda de coyuntura favorable el acceso al mercado estadounidense a través del tratado de reciprocidad comercial (15), un criterio que, como quedó explicado en los párrafos anteriores, es contrario a la perspectiva divulgada por la oficialidad.

Semejante a esta postura, algo ambivalente, está el trabajo de Enrique Fernández ${ }^{73}$, quien por una parte justifica la gestión del gobierno, al descontextualizar el

\footnotetext{
${ }^{72}$ Oscar Zanetti es uno de los historiadores e investigadores cubanos más destacados que ha dedicado parte de sus estudios a la historia del azúcar en la nación. Su obra Caminos para el azúcar (1987) —en coautoría con Alejandro García - es la investigación más completa que se haya realizado sobre la historia del ferrocarril - al servicio del azúcar - en Cuba. La ponencia que presentó para este evento fue publicada bajo el título "Historia y azúcar" (15-25).

${ }^{73}$ Enrique Fernández, arquitecto que ejerce como profesor de la Facultad de Arquitectura del Instituto
} 
hecho, mientras que por otro lado muestra una sincera preocupación por el futuro de las comunidades afectadas. Según Fernández, cambios económico-productivos, similares a la drástica reducción de la agroindustria azucarera cubana, se estaban dando en otras regiones del mundo. Como ejemplo, cita a la ciudad alemana de Dortmund, históricamente ligada a la producción del carbón y a la industria del acero, que luego de que se viese obligaba a cerrar estos sectores, pasó a la industria del software (39). Lo curioso de su cita, más allá de sacar del contexto cubano el asunto que ese día los reunía, fue atreverse a comparar una nación que durante décadas se ha venido ahogando en una crisis económica, por el momento perpetua, con una de las economías más poderosas y estables del mundo — destacada, justamente, por haber podido asumir económicamente a Alemania Oriental, después de la reunificación-. Por otra parte, y a diferencia de lo que estaba sucediendo en Cuba —algo que continuaría a pesar de los años y los diversos planes propuestos-, Alemania sí había logrado hallar, después del cierre de sus industrias, una solución favorable para la región y sus habitantes, no sólo a través de la sustitución industrial, que propició la reanimación económica, sino también de la conservación de su patrimonio (39). No obstante, y después de este desacertado paragón, Fernández regresa a la realidad cubana para postular una pregunta que pocos se atrevieron a articular durante el evento:

aquí hemos estado oyendo los planes que hay en relación con la recuperación del patrimonio edificado, con el patrimonio urbano y arquitectónico ... quisiera referirme a los bateyes que no tienen un patrimonio arquitectónico notable y no van a ser convertidos en museos, que quizás no van a ser objeto de restauraciones importantes .... Se trata de sitios donde se producía y tenía una determinada actividad y movilidad,

Superior Politécnico José Antonio Echeverría (ISPJAE), presentó en el evento una ponencia que fue publicada bajo el título "Transformaciones del batey azucarero en Cuba" (34-40). 
dadas precisamente por la actividad productiva, se acaba toda movilidad y desaparece también la actividad.

. . ¿qué va a pasar con estos sitios?, ¿qué va a pasar con estos lugares donde el cascarón que era el central realmente no es un objeto museable, ni tampoco se considera recuperable para alguna otra función en el propio sitio? [énfasis añadido]. (40)

Se abría con sus palabras un breve espacio donde, alejado de la retórica oficial, la incertidumbre acerca del futuro de las comunidades afectadas tenía cabida. Más allá de la necesidad de salvaguardar el patrimonio azucarero, tema que dominó gran parte del evento, Fernández, solapadamente, exigía soluciones, preguntándose cuáles serían las alternativas (40). La coyuntura, sin embargo, no terminó siendo un espacio donde se debatiera seriamente acerca del impacto de la reestructuración. No abundaron los detalles ni las anécdotas personales; no se ahondó en el desamparo existencial que sufrían los ciudadanos ante la eminente carencia de sus referentes culturales e identitarios; ni se habló de la miseria a la que quedaban sumidos los zafreros, reflejada en los bateyes en ruinas. La realidad quedó más bien silenciada al concluir Fernández su intervención con la vaga idea de planes futuros, que compusieran el mal.

Siguiendo la línea de Fernández, Juan Valdés $\mathrm{Paz}^{74}$, durante su breve intervención, también expresa una preocupación ante la falta de soluciones.

Y en lo que respecta a la cuestión de la cultura ... me preocupa más que no tengamos las condiciones adecuadas para seguir recreando la cultura azucarera, y menos que nos olvidemos de la que tuvimos; me preocupa más que, como resultado de esta transformación azucarera, se nos creen vacíos sociales. Entonces sí vamos a tener un problema con la cultura azucarera. Si me dicen que en un pueblo desaparecieron los únicos tres centrales, y no oigo decir cuál es la industria o la ocupación alternativa que se creó, entonces sí tengo preocupación acerca de la continuidad de esa cultura [énfasis añadido]. (80)

\footnotetext{
${ }^{74}$ Juan Valdés Paz, sociólogo y filósofo que ejerce como profesor en la Universidad de La Habana y en el Instituto Superior de Relaciones Internacionales (INRI). Su participación en el evento fue recogida en el número de Catauro bajo la sección de Intervenciones (80-81).
} 
Con estas palabras presentaba Valdés un orden de prioridades distinto al que al parecer había predominado en el evento. Más allá de la conservación de la dimensión tangible de la cultura azucarera - la posibilidad de preservar el patrimonio para evitar que este legado cayera en el olvido-, a Valdés le angustiaba la falta de alternativas que pudieran suplir el vacío socioeconómico que la reestructuración dejaba y lo exponía, abiertamente, en su intervención. Para él, más que museos de la memoria, hacían falta soluciones pragmáticas que pudieran asegurar la continuidad de la comunidades afectadas.

Por su parte María del Carmen Barcia ${ }^{75}$, otra de las participantes al evento, manifestó su desacuerdo con el concepto del estudio como empleo, indicando que este no era un problema que únicamente se pudiera solucionar incorporando a los trabajadores afectados al estudio.

Hay algunos trabajadores ya bastante mayores, y en estos casos el tiempo que van a estar estudiando no van a producir resultados socialmente provechosos. A mi modo de ver, no se trata de entretenerlos [énfasis añadido], sino de hacer algo que pueda ser útil en esta visión de futuro que consideramos que es importante tener. (94)

Barcia, además, aseguró que tanto los historiadores como los integrantes de la esfera política, sabían desde hacía mucho tiempo que la industria azucarera necesitaba diversificarse para no perecer. En su intervención recordaba como en los años sesenta el gobierno había organizado varios eventos donde "se explicaban las dificultades que afrontaba la industria [ . . . y cómo no podría continuar su desarrollo si no se introducían otras variantes que incluyeran otros derivados" (93). A pesar de que justificaba la inacción del régimen respecto a esta realidad, argumentando que por razones

\footnotetext{
75 María del Carmen Barcia es una historiadora que ejerce como profesora en la Universidad de La Habana. Es, además, miembro del Consejo Científico de la Fundación Fernando Ortiz. Su intervención en el evento fue publicada en el número de Catauro bajo la sección de Intervenciones (93-94).
} 
seguramente valederas [énfasis añadido] no se habían implementado disposiciones para salvar este sector económico con anterioridad, criticaba la premura con la que se había llevado a cabo la reestructuración. Según ella, las medidas adoptadas en tan breve lapso de tiempo habían sido demasiado radicales, al punto de que no sólo afectaban a la industria, sino también a las personas cuyas vidas giraban en torno al batey azucarero. Este tipo de rupturas, señalaba, siempre resultaban siendo peligrosas (93-94).

De todas las intervenciones publicadas en el número de Catauro la de Barcia llega a ser, quizás, la más radical. Manifestarse en contra de una política que había sido introducida por el Comandante en Jefe —el estudio como empleo-, tildándola como mero entretenimiento, y asegurar que la cúpula gubernamental, desde la década de los años sesenta, sabía lo que podía suceder con el sector azucarero si no se producían cambios, era una postura bastante atrevida dentro de un evento que había sido organizado por instituciones culturales que responden a la oficialidad. No obstante, y a pesar de estos momentos donde la intelectualidad se deslinda del poder para mostrar una sincera preocupación por el futuro de los trabajadores azucareros, en este seminario las posibilidades de representar la realidad — que de por sí es anti-hegemónica— serían limitadas. No fue esta convocatoria el espacio donde las víctimas directas pudieran alzar su voz. No fue cierto que en ella, excepto en breves menciones, se debatiera acerca del desamparo y el trauma, mucho menos acerca de las soluciones ilegales o moralmente discutibles, a las que las personas se vieron obligadas a recurrir para subsistir ${ }^{76}$.

A pesar de estas omisiones y de las posturas políticas o del nivel de compromiso

\footnotetext{
${ }^{76}$ Respecto a las soluciones a las que tuvieron que acudir las personas afectadas por la reestructuración, puede leer el último capítulo de este estudio donde analizo la película Melaza (2012) de Carlos Lechuga.
} 
que pudieran tener los participantes con el poder, la realización de este evento, apenas un año después de iniciada la restructuración, tuvo un valor indiscutible. Con él quedó demostrado que el cierre de los centrales, a diferencia de lo que hubiera planteado Fidel Castro, sí había tenido consecuencias nefastas para la nación, al punto de movilizar a su intelectualidad en torno a este acontecimiento. Existía una preocupación real por el bienestar de las comunidades afectadas y por el futuro de la industria azucarera, tanto por parte de los intelectuales como de los ciudadanos, que se traducía en una especie de urgencia, enfrentada al silenciamiento oficial. Era necesario no sólo intentar hallar soluciones sino poder hablar abiertamente acerca de la crisis azucarera, poder representar su realidad sin restricciones, no ya desde el poder, sino desde los márgenes. Quedaba preguntarse ¿dónde encontraría esta urgencia un espacio alejado del discurso oficial?

La respuesta se halló en una producción cultural que dejó de reproducir los mitos legitimadores de la Revolución; que se desentendió de la versión oficial de la historia, específicamente de su capítulo azucarero, para no atenuar el efecto de la reestructuración y que se opuso al silenciamiento de la realidad. Algunos artistas entendieron la necesidad de representar el síndrome del central ${ }^{77}$ e incluyeron, a veces, su lado más abyecto. La posibilidad de que este episodio de la historia cubana se enmascarara tras la retórica triunfalista y descontextualizadora del régimen, de que la intelectualidad domesticada como buenos historiadores del poder - insistiera en aferrarse a la versión oficial de los hechos, presuponía un grave peligro, ya no para la Historia, que en definitiva desde la perspectiva posmoderna se entiende como un proceso discursivo del poder imperante,

\footnotetext{
${ }^{77}$ En su testimonio en La callada molienda, Gladys Abreu Cárdenas define como síndrome del central la enorme tristeza y añoranza que sienten los zafreros por el central (183).
} 
sino para la memoria colectiva de toda una comunidad. ¿Cómo iba a ser recordado el cierre y posterior desmantelamiento de los centrales azucareros en la primera década del siglo XXI cubano? ¿En qué lugar se posicionaría el sufrimiento y el trauma de los zafreros, si lo que prevalecía en la Historia - y en la memoria - eran acontecimientos embellecidos dignos de imitar? (aquellos con los que, según Nietzsche, se alimentaba toda historia monumental). Evidentemente no iba a ser la oficialidad, ni su cultura, la que procurara representar y divulgar esta realidad y para intentar responder a estas preguntas, se tendría que recurrir necesariamente a la manifestación cultural anti-hegemónica.

En el último capítulo de este estudio me centraré en las propuestas realizadas por algunos de los jóvenes artistas cubanos, quienes dentro de diversas disciplinas y géneros artísticos se han acercado a este capítulo de la historia desde una perspectiva crítica, que contradice la depurada y selectiva versión oficial. Previo a este estudio, y debido a que la reestructuración ha creado la urgencia de rescatar el papel que el azúcar ha jugado en la Historia, la identidad y la cultura de la nación, analizaré varias obras — desde la época colonial hasta las primeras décadas de la revolucionaria - con el fin examinar la representación del azúcar en el devenir histórico y cultural de la nación. 


\title{
CAPÍTULO 2
}

\author{
AZÚCAR, NACIÓN Y PAISAJES EN LA ERA COLONIAL: INFLUENCIA DE LA
}

\author{
AGROINDUSTRIA AZUCARERA EN LA IDENTIDAD Y LA
}

\author{
MANIFESTACIÓN CULTURAL NACIONALES
}

2.1. TEXTOS HISTÓRICOS Y JURÍDICO-ECONÓMICOS FUNDACIONALES: EL

\author{
TEMOR AL NEGRO Y LA IMAGINADA NACIÓN BLANCA EN LOS \\ DISCURSOS AZUCAREROS DE LA ÉPOCA
}

En vano se les ha opuesto [a las metrópolis] la despoblación del terreno que quieren ver cultivado, pues aunque en sus propios dominios no han encontrado para esto los recursos necesarios, o sea, los brazos precisos, las costas occidentales de África allanan este inconveniente abriéndoles un manantial de hombres lo más a propósito para su interesante objeto.

-Francisco de Arango y Parreño

Más se necesita [en Cuba] de la inteligencia del blanco que de la fuerza muscular del hombre de color... Cuba debiera ser por excelencia la patria de la pequeña propiedad y de los cultivos en escala menor...

Sin exceptuar la caña de azúcar todas sus labranzas convidan al trabajo y la inmigración [europea]. -Francisco de Frías y Jacott

Aunque desde inicios del siglo XVI, a raíz del período de conquista encabezado por Diego Velázquez (1465-1524), la caña de azúcar no sólo había sido introducida en Cuba, sino que se producía y exportaba su dulce a la Metrópoli y a tierras vecinas según explica Fernando Ortiz (653-654)—, no será hasta mediados del siglo XVIII, debido mayormente a coyunturas internacionales ${ }^{78}$, que la agroindustria azucarera se convierta en un renglón imprescindible para la economía de la Isla y que su constante presencia en el territorio nacional comience también a imponerse en el creciente corpus

\footnotetext{
${ }^{78}$ Para información detallada sobre cuáles sucesos internacionales impulsaron el crecimiento de la industria azucarera cubana en el siglo XVIII, consulte los acápites "La coyuntura internacional, 1700-1760" (1115) y "La coyuntura internacional, 1760-1792" (27-36) de la obra El ingenio de Manuel Moreno Fraginals.
} 
literario.

En Llave del Nuevo Mundo (1759-60) ${ }^{79}$, considerada una de las primeras obras históricas nacionales, ya José Martín Félix de Arrate (1701-1765) exponía que, además del tabaco, a finales de la década del cincuenta del siglo XVIII las cañas dulces constituían "las cosechas más largas y de mayor utilidad" (13). Unos años más tarde, después que la ciudad de La Habana hubiera visto un importante auge económico bajo la dominación inglesa (1762-1763) — derivado, entre otras cosas, gracias a la posibilidad que tuvo la ascendente sacarocracia de comprar más esclavos durante ese períodoFrancisco de Arango y Parreño (1765-1837), en calidad de Apoderado General de la ciudad de La Habana, comenzaba a componer una serie de documentos que abogaban por la introducción de negros para extender el cultivo de la preciada planta en el territorio nacional.

A pesar de que varios de estos escritos ${ }^{80}$ daten algo antes del triunfo de las primeras sublevaciones de esclavos en Haití a finales de agosto de 1791—que desembocarían en la llamada Revolución haitiana (1791-1804)—, no será hasta que se tenga noticia de ésta el 19 de noviembre del mismo año, según el propio Arango (140), que éste advierta la posibilidad que se abría para la Isla ante la catástrofe de la colonia

\footnotetext{
${ }^{79}$ Aunque la dedicatoria de la obra se firmó en 1761 y la publicación no se realizó hasta 1831 , los acontecimientos relatados en esta obra abarcan hasta los años 1759-60.

${ }^{80}$ Los siguientes documentos fueron presentados por Arango antes de que se tuviera noticia de la sublevación de esclavos en Haití: "Primer papel sobre el comercio de negros", firmada el 6 de febrero de 1789 (117-121); "Representación manifestando las ventajas de una absoluta libertad en la introducción de negros, y solicitando que se amplíe a ocho la prórroga concedida por dos años", firmada el 10 de mayo de 1791 (131-135); "Ofício acompañando copia de la representación sobre la introducción de negros, y corroborándola con razones muy sólidas", firmada el 9 de agosto de 1791 (138-139). Todos se pueden consultar en la obra Francisco de Arango y Parreño. Obras (Volumen I), compilada por la Biblioteca de Clásicos Cubanos y publicada por Ediciones Imagen Contemporánea en el año 2005.
} 
vecina y presente su "Representación con motivo de la sublevación de esclavos" 81 (1791). Este documento, por su parte, sirvió de antesala para introducir el que sería su más famoso escrito a favor del desarrollo de la agroindustria azucarera en Cuba: el "Discurso sobre la agricultura de La Habana y medios de fomentarla" (1792). Con este texto, como bien apunta Antonio Benítez Rojo en su artículo "Azúcar, poder y literatura" (1988), aunque no fuera el primero de su tipo — ya Agustín Crame había escrito su "Discurso político" 82 unos años antes-, sí queda legitimada la sacarocracia cubana y su discurso a favor del azúcar, gracias al apoyo de la Corona, se convierte en el discurso dominante.

En el mencionado artículo Benítez Rojo expone que a este discurso de plantación, propio de lo que Heinrich Friedländer ${ }^{83}$ denominara la Cuba Grande, "la del ingenio . . . autoritaria, soberbia, insensible; [. . .] que tiende a reducir la sociedad a los requerimientos de la producción, de la tecnología y, sobre todo, de la demanda mercantil” (201) —en palabras de Benítez Rojo—, se le enfrenta un discurso de resistencia, antiazúcar, que nace en la Cuba Pequeña, definida como "la heredera de lo Criollo y de la heterogeneidad característica de la sociedad preazucarera" ${ }^{\prime 4}$ (201). Una Cuba que se beneficiaba y promovía la agroindustria azucarera e introducción de más esclavos -

\footnotetext{
${ }^{81}$ Título original: "Representación hecha a su majestad con motivo de la sublevación de esclavos en los dominios franceses de la Isla de Santo Domingo" (140-143), firmada el 20 de noviembre de 1791.

${ }^{82}$ Referencia al "Discurso político sobre la necesidad de fomentar la Isla de Cuba acompañado de una breve descripción de sus principales pueblos y planos de toda la Isla" (1768) de Agustín Crame. Según Leida Fernández Prieto, en "Crónica anunciada de una Cuba azucarera" (2009), cada vez más se considera este texto como la obra fundacional dentro del discurso de la plantación (40).

${ }^{83}$ Historia económica de Cuba (1944).

${ }^{84}$ La idea de una Cuba Grande enfrentada a una Pequeña la toma Benítez Rojo del estudio de Heinrich Friedländer mencionado en la nota anterior. En capítulos posteriores seguiré ahondando sobre estos conceptos.
} 
grandes hacendados, mayormente de La Habana en ese momento (aunque luego el azúcar fue abriéndose paso por toda la Isla, sobre todo por la región Occidental y Central del país ${ }^{85}$ ) y negreros, con apoyo, esta vez, del gobierno y la Corona- encontraba resistencia frente a otra Cuba que se sentía amenazada ante la marcha violenta e infalible de la gran plantación y parecía horrorizarse ante la trata — campesinos pequeños o medianos (incluidos tabaqueros) y hacendados ganaderos, en su mayoría de la región de Puerto Príncipe y más tarde del Oriente del país ${ }^{86}$, entre otros-.

Para efectos de este estudio, más allá de las motivaciones socioeconómicas que incitaron este contra-discurso, me interesa reflexionar en las profundas raíces racistas ${ }^{87}$ que lo motivaron y como este racismo, manifestado en una gran aversión hacia lo africano — incluido un alarmante temor al negro ${ }^{88}$ — terminó trascendiendo a la literatura del azúcar, afectando la manera en que fue representada esta industria en la cultura, por estar asociada a la bárbara raza.

Aunque no carezcan los escritos de Arango del llamado temor al negro, probablemente el hecho de que la mayoría de la población africana, o afrodescendiente,

\footnotetext{
${ }^{85}$ Cabe destacar, que aunque La Habana fue la primera región que vivió el despegue azucarero, el azúcar, en mayor o menor medida, fue poco a poco cubriendo toda la Isla. Matanzas, Trinidad, Cienfuegos, Sagua, entre otras, fueron regiones que durante el siglo XIX vieron un incremento de la agroindustria azucarera. Información detallada de este proceso se puede encontrar en el acápite "El azúcar descubre la Isla" (117127) de la obra El ingenio (1978) de Moreno Fraginals.

${ }^{86}$ En el acápite mencionado en la nota anterior, Moreno Fraginals explica como la región de Puerto Príncipe se convirtió en un foco de choque contra el concepto habanero de plantación y como la región Oriental, con una menor y muy atrasada industria azucarera, también terminó enfrentándose a este modelo económico.

${ }^{87}$ Varios trabajos académicos se han dedicado al estudio del racismo en la sociedad cubana, incrementado a partir de finales del siglo XVIII, a raíz de la expansión azucarera. Me atrevo a recomendar Racismo e inmigración en Cuba en el siglo XIX (Consuelo Naranjo Orovio y Armando García González [1996]).

${ }^{88}$ Para más información sobre el temor que sentían los blancos ante una posible sublevación de esclavos y ante la inminente africanización de la Isla puede consultar Miedo negro, poder blanco en la Cuba Colonial (Jorge Camacho 2015).
} 
todavía no era una realidad, propició que sus deseos de impulsar la agroindustria azucarera superaran esta inquietud y adoptara una postura mucho más esperanzadora. Tanto en la "Representación con motivo a la sublevación de esclavos" como en el "Discurso sobre la agricultura de La Habana", el Apoderado admite este miedo por parte de sus coterráneos, pero insiste en que hay diferencias fundamentales entre ambas colonias, que libraran a Cuba del horror. No obstante, leyendo ambos documentos, uno no puede dejar de advertir como en el segundo el temor de sus compatriotas - incluso el suyo propio - ha hecho resistencia a sus planes, por lo que, además de excusas que apacigüen el miedo, ofrece soluciones al posible futuro mal.

Al ruido de este funesto suceso [la sublevación de esclavos], he despertado y he vista (sic) que toda mi obra se sostenía en el aire; que nada había trabajado para darle subsistencia, que el sosiego y reposo de todos mis compatriotas, el goce de las felicidades que iban a conseguir estaba pendiente de un hilo: de la subordinación y paciencia de un enjambre de hombres bárbaros. No es hoy cuando más me espanta esta desagradable advertencia. La suerte de nuestros libertos y esclavos es más cómoda y feliz que lo era la de los franceses. Su número es inferior al de los blancos, y además de esta debe contenerlos la guarnición respetable que hay siempre en la ciudad de La Habana. Mis grandes recelos son para lo sucesivo, para el tiempo en que crezca la fortuna de la Isla y tenga dentro de su recinto quinientos mil o seiscientos mil africanos. Desde ahora hablo para entonces, y quiero que nuestras precauciones comiencen desde el momento. (171)

Admitía Arango con estas palabras que el temor al negro no era infundado, pero que el real peligro radicaba en el futuro, cuando la población negra y mulata superara la blanca, por lo que proponía remedios para evitar la tragedia. Además de la amenaza que constituiría el lógico crecimiento poblacional afrodescendiente, debido al incremento de la trata y acrecentada por la despoblación de blancos — lo cual dejaba a los campos a merced del poder negro- (172), Arango señalaba que la existencia, dentro de la milicia, 
de dos batallones compuestos por negros y mulatos libertos también representaba un peligro para la seguridad interior de la Isla, ya que estos, en caso de una revuelta de la gente de color, pudieran ofrecerle a los sublevados la disciplina militar, ventaja que dejaría de ser exclusiva de los blancos (171). Ante estas contingencias, sugería el Apoderado que la Real Junta Protectora de Agricultura, institución que proponía debía crearse a raíz de su plan económico, examinará la posibilidad de sustituir los batallones de negros y mulatos por soldados blancos y de aumentar la población blanca en los lugares de la Isla más convenientes, además de acrecentar la policía de los campos (176$177)^{89}$. Más adelante, escribiría otros documentos que también servirían al propósito de contener la amenaza negra, como fuera el "Nuevo reglamento y arancel que debe gobernar en la captura de esclavos cimarrones" (1796), con el que se trataba de dulcificar el trato al esclavo, ayudándolo a soportar su condición de una manera más llevadera para así apaciguar su hostilidad hacia la institución que lo oprimía. También abogaría, adoptando una postura más próxima a los reformistas, por una política de blanqueamiento de negros mediante la mezcla interracial ${ }^{90}$, que además de blanquear la sociedad y borrar la memoria de la esclavitud, supliera a la agricultura los brazos necesarios una vez que el sistema esclavista se aboliera ${ }^{91}$ ("Ideas sobre los medios", 153-154).

A pesar de su naturaleza jurídico-económica, después de analizar algunos

\footnotetext{
${ }^{89}$ Todas estas propuestas quedaron estipuladas en el "Proyecto", apartado del Discurso donde desglosa en detalles los pasos a seguir para cumplir con su plan económico.

${ }^{90}$ Arango entendía que la raza negra siempre cedía a la blanca y que después de varios cruzamientos cedería. Estas ideas las expuso en el apartado "Futura seguridad y tranquilidad de la Isla" del documento "Ideas sobre los medios de establecer el libre comercio de Cuba y de realizar un empréstito de veinte millones de pesos", firmado en Madrid el 25 de agosto de 1816.

${ }^{91}$ Cabe destacar que en los últimos años de su vida el propio Arango abogaría fehacientemente por la eliminación de la trata como lo demuestra su documento "Representación al rey sobre la extinción del tráfico de negros y medios de mejorar la suerte de los esclavos coloniales" (1834).
} 
fragmentos del "Discurso sobre la agricultura", no sería desacertado calificarlo como un texto fundacional de la nación cubana, donde Arango imaginaba a la Isla como un espacio para blancos, cuya prosperidad y felicidad dependía de los esclavos negros aunque paradójicamente no concibiera a esta raza dentro del proyecto nacional—. Esta contradicción, la blanca comunidad imaginada vs. la africanizada comunidad real, que responde a lo que David Theo Goldberg llamara la negación de la heterogeneidad ${ }^{92}$, será mucho más latente en las próximas décadas, cuando el incremento de la población negra y mulata se convierta en una realidad. A diferencia de Arango — quien advertía la amenaza negra pero estaba convencido, al menos durante estos años, de que tomando ciertas precauciones una sublevación de negros y mulatos podía evitarse-, el miedo a la barbarie negra dominará el discurso anti-azúcar de sus oponentes, a tal punto, que las supuestas motivaciones filantrópicas que los llevaran a escribir textos antiesclavistas (incluyendo obras literarias), pudieran quedar oscurecidas.

En los párrafos introductorios de "Proyecto y memoria para la extinción de la esclavitud en la Isla de Cuba"93 (1822), Félix Varela y Morales (1788-1853) narra como la Corona, tras el exterminio de la raza india en manos de los conquistadores españoles, no se preocupó por poblar la Isla de nacionales o extranjeros (europeos blancos), y como más tarde, ante la ausencia de brazos que se encargaran de las labores agrícolas en los campos, se dejó seducir por Inglaterra, autorizando la consolidación del tráfico de esclavos negros (113-114).

\footnotetext{
${ }^{92}$ En Miedo negro, poder blanco en la Cuba colonial (2015), Jorge Camacho hace alusión a este concepto de David Theo Goldberg, quien, en su obra The Racial State (2002), explica la negación de la heterogeneidad como la tendencia en los estados naciones modernos a negar la presencia de personas no blancas dentro del proyecto nacional. Sobre este concepto profundizaré en los acápites posteriores.

${ }^{93}$ Aunque escrito para presentarlo en las Cortes de 1822-23, Varela nunca llegó a presentar este Proyecto.
} 
Lo que inicialmente podía leerse como una crítica al genocidio de las razas amerindias y a la esclavitud de las razas africanas, sin otras motivaciones que no fueran un deseo puro de condenar injusticias humanas, muy pronto va dando paso a preocupaciones de naturaleza menos altruista. El consabido temor a una sublevación de esclavos similar a la de Haití se había incrementado, según había aumentado el índice poblacional de los negros y los mulatos, quienes conforme a estadísticas mencionadas por Varela en este texto, a inicios del año 1821 ya excedían a la población blanca ${ }^{94}(115-$ 116). Además de este crecimiento numérico de la comunidad afrodescendiente, la importancia que los negros y mulatos libres o libertos iban adquiriendo en la sociedad cubana ${ }^{95}$ también lo desconcertaba. No podía, sin abandonar sus ideas racistas, evitar admirarse ante la increíble capacidad de superación y los logros que estos hombres habían alcanzado, advirtiendo que este florecimiento afectaba y constituía un peligro para los blancos.

Estos [los negros y mulatos libres dedicados casi todos a las artes mecánicas o liberales] tienen una instrucción, que acaso no podía esperarse, pues la mayor parte de ellos saben leer, escribir y contar y además su oficio que algunos poseen con bastante perfección, aunque no son capaces de igualar a los artistas extranjeros, por no haber tenido más medio de instruirse que su propio ingenio [énfasis añadido]. Muchos de ellos están iniciados en otras clases de conocimiento, y acaso no envidian a la generalidad de los blancos.

La necesidad, maestra de los hombres, hizo que de su infortunio sacaran los originarios de África estas ventajas, pues hallándose sin bienes y sin

\footnotetext{
${ }^{94}$ Unida a la necesidad de brazos que exigía el crecimiento de la agroindustria azucarera, el desespero de los sacarócratas por comprar más negros se acentúa a partir de 1807, cuando queda oficialmente abolida la trata en Inglaterra y en Estados Unidos. Según Moreno Fraginals, entre 1809 y 1820 - año en que debía finalizar el tráfico negrero en Cuba según el Tratado Anglo-español de 1817-, se introdujeron en la Isla alrededor de 152.000 negros africanos (El ingenio, 217-218).

${ }^{95}$ Un ejemplo vivo de la importancia que iba adquiriendo esta pequeña burguesía afrodescendiente en la sociedad cubana de la época se aprecia en el exitoso sastre, Francisco Uribe, de la novela Cecilia Valdés. Según Pedro Deschamps Chapeaux (1970), Cirilo Villaverde había tomado como referencia a un sujeto real para crear este personaje.
} 
estimación han procurado suplir esas faltas en cuanto les ha sido posible por medio de trabajo, que no sólo les proporciona una cómoda subsistencia sino algún mayor parecido de los blancos; al paso que estos han sufrido un golpe mortal por la misma civilización de los africanos. Efectivamente, desde que las artes se hallaron en manos de negros y mulatos se envilecieron para los blancos, que sin degradarse podían alternar con aquellos infelices. (116)

Si de los esclavos se dependía para la agricultura y el servicio doméstico, había que acudir a los negros y mulatos libres para otros servicios y labores, a las cuales los blancos no querían asociarse, justamente porque se empezaban a percibir como oficios de gente de color. Era tal el poder que iba adquiriendo esta clase, que si tuviera la intención de arruinar a los blancos, según Varela, bastaría con que suspendiera sus trabajos y exigiera la libertad de sus hermanos esclavos y los derechos políticos que se le negaban (116118).

Más allá de las ideas revolucionarias que pudieran haber influenciado el pensamiento de Varela en este discurso — los ecos de la Revolución Norteamericana (1763-1787), que promulgaba el derecho inalienable de todo hombre a preservar la vida y la libertad y a procurar la felicidad ${ }^{96}$, o de la Revolución Francesa (1789-1799), que llamaba a la libertad, igualdad y fraternidad ${ }^{97}$ entre todos los hombres-, el temor al negro era quizás el motivo más latente que impulsara esta actitud antiesclavista. Ya sea porque se temiera una sublevación que pusiera en peligro la estabilidad socioeconómica de la Isla, y con ella el bienestar de los blancos, o porque la innegable africanización de la

\footnotetext{
${ }^{96}$ Fragmento tomado de la Declaración de Independencia de Estados Unidos (1776). En el texto original redactado por Thomas Jefferson, recopilado por la Biblioteca del Congreso, se lee: "We hold these truths to be sacred \& undeniable; that all men are created equal \& independent, that from that equal creation they derive rights inherent \& inalienable, among which are the preservation of life, \& liberty, \& the pursuit of happiness".

${ }^{97}$ Nacida durante la Revolución Francesa, "Libertad, igualdad, fraternidad" ("Liberté, égalité, fraternité"), fue una consigna que se convirtió en el lema de quienes luchaban por librarse del yugo monárquico u otras formas de opresión.
} 
sociedad continuara, tragándose a su paso a la cultura ibérica —idealizada por los blancos como la única depositaria de la identidad nacional—, era el miedo quien moldeaba el discurso. Unido a este miedo, sin embargo, se encontraban sin duda las nuevas exigencias del capitalismo industrial.

No hay que olvidar que la inicial introducción en masa de esclavos negros fue justamente la única solución que halló la sacarocracia para suplir la carencia de brazos durante la expansión de la agroindustria azucarera, en una isla prácticamente despoblada $^{98}$, y que uno de los argumentos que esgrimiera Varela para abogar por la abolición de la esclavitud era el seguro abaratamiento de la mano de obra libre una vez que ésta cesara. Varela recordaba en el documento que los trabajadores libres, aprovechando su alta demanda, exigían salarios mucho más elevados que los que se pagaran en Europa por los mismos servicios (115), de ahí que en el siguiente Proyecto ${ }^{99}$ que presentara, que servía de apéndice al primero, estipulaba que a raíz de la emancipación, los negros libertos tenían que incorporarse a la agricultura, las artes, el servicio doméstico o alguna otra ocupación útil ${ }^{100}(122)$. La liberación de los negros, unida a los proyectos de inmigración y colonización blanca ${ }^{101}$, se concebían como las

\footnotetext{
${ }^{98}$ Para más información sobre como la sacarocracia suplió la carencia de brazos puede remitirse al capítulo "El mercado de brazos (1790-1860)" de la obra El ingenio de Moreno Fraginals.

99 "Proyecto de decreto sobre la abolición de la esclavitud en la Isla de Cuba y sobre los medios de evitar los daños que pueden ocasionarse a la población blanca y a la agricultura" (1822).

${ }^{100}$ E1 Proyecto convenía una serie de mandatos que garantizaban que los libertos se incorporaran al trabajo para que la abolición no afectara ni a la población blanca ni a la agricultura. Uno de ellos estipulaba que las Juntas Filantrópicas de cada distrito — creadas específicamente para este proyecto - tenían la autoridad de destinarle una ocupación determinada a los libertos que estuvieran desempleados por un período de más de dos meses. Otro les prohibía mudarse a la capital, por un período de cuatro años, a los esclavos del interior que fueran puestos en libertad gracias al sorteo de la Junta Filantrópica ("Proyecto de decreto", 122-125).

${ }^{101}$ Hubo durante todo el siglo XIX y parte del XX varios proyectos de colonización y de importación de trabajadores blancos. En 1812, por ejemplo, se creó, dentro de la Sociedad Económica de Amigos del País,
} 
soluciones acertadas para obtener la mano de obra asalariada - barata - que la sacarocracia tanto deseara y para contener la amenaza negra.

Si para Arango la prioridad era el incremento de la trata, arguyendo que sólo a través de ella lograría la Isla despojarse de su atraso económico, alcanzando el desarrollo de las grandes colonias azucareras (Jamaica y, sobre todo, Haití), para Varela era justamente el resultado de este tráfico el que amenazaba la prosperidad. "Un átomo al lado de un coloso era lo que figurábamos respecto de nuestros vecinos" (“Representación”, 142), decía Arango a finales del siglo XVIII. Un coloso sobre arena al que probablemente agiten fuertes huracanes sino consolidamos sus cimientos con anticipación ("Proyecto y memoria", 119), esgrimía Varela tres décadas después. Tanto la trata como su abolición se concebían desde y para el blanco, en pos de su bienestar económico, primero, y luego para mantener su supremacía económica y cultural en la sociedad. Entre estos dos discursos - el de la plantación y el que intentaba hacerle resistencia-, el temor y la aversión al negro, en mayor o menor medida, siempre existió.

Este miedo — y este rechazo— también dominó el discurso de José Antonio Saco (1797-1879), discípulo de Varela y, de cierta manera, continuador de sus ideas. En 1832, con el afán de romper el silencio que existía en torno a la que él llamara la enfermedad de la sociedad cubana del momento (el sistema esclavista), publica su “Análisis por don José Antonio Saco de una obra sobre el Brasil"102. Similar al texto de Varela antes analizado,

la Comisión de Población Blanca que a partir de 1818 pasaría a llamarse Junta de Población Blanca. Para más información sobre este tema puede consultar el capítulo "Colonización blanca y esclavitud, programas complementarios" de la obra Racismo e inmigración en Cuba en el siglo XIX (1996) de Consuelo Naranjo Orovio y Armando García González.

${ }^{102}$ Título original: "Análisis por don José Antonio Saco de una obra sobre el Brasil, intitulada, Notices of Brazil in 1828 and 1829 by Rev. R. Walsh author of a journey from Constantinople, etc. (Noticias del 
lo que inicialmente se leía como una crítica a la trata negrera - "el horrible comercio de carne humana" (64), como la llamara - muy pronto traslució un acuciante temor a la amenaza negra.

[E]n una población [hablando de la Isla de Cuba] donde hay poco mas de 300,000 blancos, se cuentan casi 500,000 personas de color.

Estas indicaciones son por sí bastantes para conocer que nos hallamos gravemente enfermos [énfasis añadido], y que si no aplicamos el remedio con manos firme, la muerte puede sorprendernos en medio de la aparente felicidad de que gozamos.

Todavía nuestra situación será más comprometida, si volvemos los ojos al horizonte que nos rodea. Con ellos vemos ya el humo y el fuego que se levantan de los volcanes que se han reventado; y el horrendo combustible que devora las entrañas de las Antillas, amenaza una catástrofe general en el Archipiélago americano. Leed compatriotas, leed la historia del porvenir en los padrones que sometemos a nuestro examen, y después de haberlos meditados con la detención que merecen, decidnos si no oís los profundos quejidos de la patria agonizante. (73)

A continuación exponía Saco una serie de datos que demostraban la superioridad numérica de las personas afrodescendientes en la mayoría de las islas caribeñas y su rápido crecimiento en el sur de los Estados Unidos (73-80), defendiendo que era un error suponer que con la abolición de la trata esta cifra disminuiría: "Mucho se engaña quien piensa, que por haber cesado ya el tráfico de esclavos en casi todas las Antillas, la raza africana retrocederá o quedará estacionara. Esto tal vez sucederá en una u otra isla pequeña; pero la masa general de la población del Archipiélago irá en aumento cada día" (77). Luego de exponer estas alarmantes cifras, acusaba a los negreros y a sus cómplices de parricidas y exhortaba a los cubanos a salvar a la patria (del peligro negro) (81). Veía en la política de colonización negra de los Estados Unidos, con sus proyectos que promulgaban la emigración de las personas afrodescendientes al continente africano, un

Brasil en 1828 y 1829 por el presbítero R. Walsh, autor de un viaje a Constantinopla, etc.). 
ejemplo a seguir, porque, según él, garantizaba la conservación de la población blanca (82) — una clara alusión a la institución estadounidense American Colonization Society (ACS) y a su programa Back to Africa, con el que, desde 1821, se estaban enviando antiguos esclavos a la recién creada colonia africana de Liberia ${ }^{103}$ - Saco, al igual que Arango y su maestro Varela, negaba abiertamente la heterogeneidad racial y cultural de la Isla, al imaginar una Cuba blanca marcada por las señas ibéricas (y europeas) de identidad heredadas por los criollos o cubanos — como más tarde se autodenominarían, una vez que adquirieran conciencia de su nacionalidad.

Inútil, y prácticamente imposible, sería analizar para este estudio todos los textos fundacionales de naturaleza histórica o jurídico-económica que reflejaran el temor $-\mathrm{y}$ la aversión - al negro en la sociedad cubana de finales del siglo XVIII y durante el siglo XIX. Además de Arango, Varela y Saco, muchas figuras pertenecientes a la elite blanca - tanto político-económica como intelectual- alzaron sus voces para exponer su preocupación ante el crecimiento de la población africana y afrodescendiente en la Isla, o al menos para dejar traslucir su rechazo al negro desde una perspectiva profundamente racista. Independientemente de si apostaban o pertenecían a la Cuba Grande de la plantación azucarera y los grandes hacendados esclavistas o a la Cuba Pequeña de la agricultura diversificada y los pequeños y medianos agricultores, de su posición a favor o en contra de la trata — negreros o abolicionistas-, el miedo a una sublevación de

\footnotetext{
${ }^{103}$ La American Colonization Society (ACS) fue una institución que se creó en 1816 para ayudar a los negros libertos a emigrar a África. En 1821 se compraron tierras en el norte de Sierra Leona, en África, y se empezaron a enviar antiguos esclavos a este territorio, nombrado Liberia. A pesar de que la institución estaba formada por hombres con diferentes motivaciones, y no faltarían en ella quienes realmente se preocuparan por el bienestar de los negros, prevalecía la idea de que los africanos y los afro-descendientes nunca se integrarían completamente a la sociedad y que su presencia amenazaba el bienestar de una nación que se percibía como blanca. La supuesta emigración voluntaria de los negros que esta entidad defendía, más bien respondía a una política de expulsión. Para más información sobre esta institución puede leer Slavery and the Peculiar Solution: A History of the American Colonization Society (2005) de Erin Burin.
} 
esclavos y la negación a la africanización de la Isla, de cierta manera, los aunó. Los nombres de Claudio Martínez de Pinillos, Alejandro Ramírez, Ramón de la Sagra, Domingo Del Monte, Gaspar Betancourt Cisneros, Francisco de Frías Jacott, entre muchos otros, bien pudieran incluirse dentro de esta clase influyente de criollos y peninsulares que imaginó a una Cuba blanca, de herencia europea, a pesar de su heterogénea composición racial y cultural.

Esta manera excluyente e irreal de concebir la nación, expulsando —o negandoel legado africano del imaginario colectivo, unida al rechazo que sintieron los románticos hacia la industrialización, terminó reflejándose en la producción literaria de la época y, de modo especial, en la literatura del azúcar, por estar relacionada la expansión azucarera a la africanización y a la industria. Muchos de los textos decimonónicos reflejaron este deseo de la clase de blanca de imaginar una Cuba sin negros, plena, también, de paisajes naturales que les sirvieran como refugio ante la civilización y como una expresión distintiva de la cubanidad. Como resultado, la representación tanto del azúcar como del negro se problematiza, por lo que son condenados asiduamente a la marginalidad. En el siguiente apartado analizaré brevemente algunos de los textos literarios fundamentales del siglo XIX, enfocándome mayormente en los espacios que ocupan el azúcar y el negro dentro del paisajismo literario. 


\subsection{LOS PAISAJES CULTURALES DE LA NOSTALGIA EN LA POESÍA DEL}

\section{EXILIO DE JOSÉ MARÁ HEREDIA: LA EXCLUSIÓN DE LA CAÑA DENTRO}

\section{DE LA SIMBOLOGÍA POÉTICA NACIONAL}

"Nunca tan hermosa cosa había visto",104, expresó Cristóbal Colón a su llegada a la Isla el 28 de octubre de 1492, para luego ofrecer una descripción del idílico paisaje abundante en árboles, flores, frutos, pájaros y palmas. Dentro de la hermosura y el verdor descrito, no había cañas. Tampoco las había en el fragmento dedicado a Cuba del poema La Florida, del andaluz fray Alonso de Escobedo, donde narraba su estancia en la villa de Baracoa un siglo después ${ }^{105}$. Se detenía el fraile a describir la extracción de oro abundante al parecer en esa región durante aquellos años ${ }^{106}$ - en manos de unos negros esclavos, la siembra de la yuca y la confección del cazabe, para luego mencionar las majestuosas palmas y comenzar a enumerar una gran variedad de frutos. Las guayabas, los plátanos, las piñas, las naranjas, los limones, los mameyes, entre otros, formaban parte de toda una naturaleza exuberante por la que se caracterizaba la Isla y que ya, desde este texto, comenzaba a ser un rasgo distintivo de su identidad.

La ausencia de las cañas en estas dos obras, que junto a Espejo de paciencia

\footnotetext{
${ }^{104}$ En la oración original que aparece en el diario, según la transcripción de fray Bartolomé de las Casas, se lee: "Dice el Almirante que nunca tan hermosa cosa vido" (Diario del primer viaje, 125).

${ }^{105}$ Según Ángel Esteban, en Literatura cubana: entre el viejo y el mar (2006), los hechos históricos narrados en este poema se sitúan en el último decenio del siglo XVI (23). El fragmento dedicado a Cuba dos últimas estrofas del canto segundo de la segunda parte, el canto tercero y las catorce primeras del cuarto - fue publicado primeramente en el primer tomo de la Antología de poesía cubana (2002) de la Editorial Verbum, realizada por Álvaro Salvador y el propio Esteban, y en la obra antes mencionada (2749).

${ }^{106}$ Según Escobedo, a la Isla de Cuba le llaman la Dorada por su abundancia en oro: “... La Dorada/dijo nuestro cristiano y fuerte bando/que encierra dentro en sí grande tesoro/que, aunque pobre de gente, no lo es de oro" (27).
} 
(1608) constituyen los orígenes de la literatura insular ${ }^{107}$, no debe extrañarse, sin embargo, si se tiene en cuenta que esta planta no es autóctona de la Isla y que no fue hasta mediados del siglo XVIII que se inició la expansión de la agroindustria azucarera y con ella, su siembra extensiva. Ya a partir de esa fecha, como bien apunta Moreno Fraginals ${ }^{108}$, los ingenios empiezan a substituir $-\mathrm{y}$ tragarse $-\mathrm{a}$ los pequeños trapiches $\mathrm{y}$ sus torres pasan a conformar parte del paisaje cotidiano ${ }^{109}(36)$. Lo mismo sucederá con los cañaverales, una mancha verde, monótona, comenzará a ocupar todas las tierras fértiles cercanas a los puertos de embarque, llevándose consigo, poco a poco, los bosques vírgenes de la Isla (36). Los árboles de maderas preciosas, que en su momento tuvieron un valor significativo para la Metrópoli, fueron mermando — sino extinguiéndosedurante el siglo XIX, dándole paso a la preciada gramínea. Los carretones de mulas y las carretas de bueyes no sólo conformaban los paisajes rurales, sino que se hicieron constantes dentro de la ciudad. Su paso de los ingenios por los campos hasta los bajos de las residencias, donde se almacenaban los azucares antes de ser llevados a los puertos, fue recorrido común (133). El azúcar, para bien o para mal, iba transformando -y homogeneizando- radicalmente el país.

Esta transformación unificadora, que indudablemente le ofrecía a la Isla una estructura monolítica, tan codiciada dentro de los procesos de formación de las naciones

\footnotetext{
${ }^{107}$ Además de La Florida de fray Alonso de Escobedo, descubierto recientemente según Esteban (ver nota 105), Espejo de paciencia (1608), atribuido al canario Silvestre de Balboa, sería el otro poema fundacional cubano anterior al siglo XVIII.

${ }^{108}$ Las citas en este párrafo fueron tomadas de los siguientes capítulos de la obra El ingenio: "Del trapiche a la gran manufactura" y "La expansión y transformación del medio" (1800-1860)".

${ }^{109}$ Sobre el impacto que tuvo la agroindustria azucarera en el paisaje natural de la Isla, además de la citada obra de Moreno Fraginals, también puede consultarse Cuban Landscapes: Heritage, Memory, and Place (2009) de Joseph L. Scarpaci y Armando H. Portela.
} 
modernas, lejos de atraer a los escritores románticos del siglo XIX, fue muchas veces criticada, cuando no expulsada de su imaginario poético nacional. A pesar de que Alexander von Humboldt, tras su estancia en La Habana y otras regiones del país durante la primera década del siglo ${ }^{110}$, incluiría a Cuba dentro de las potencias azucareras esclavistas del Caribe — “islas de azúcar y esclavos” (220), como solía llamarlas - no siempre formaron parte estos dos elementos - el negro y la caña- del repertorio de figuras simbólicas con las cuales los escritores cubanos decimonónicos de las primeras décadas definen a la patria. Cuando José María Heredia (1803-1839), en el exilio, ante las majestuosas cataratas del Niágara no puede evitar la saudade de su tierra natal, son las palmas, y no las cañas, las que su memoria evoca.

Mas ¿qué en ti busca mi anhelante vista con inútil afán? ¿Por qué no miro alrededor de tu caverna inmensa las palmas ¡ay! las palmas deliciosas ${ }^{111}$ que en las llanuras de mi ardiente Patria nacen del Sol a la sonrisa y crecen, y al soplo de las brisas del Océano bajo un cielo purísimo se mecen? (54-61) ${ }^{112}$

En un poema posterior, escrito al recibir el retrato de su fallecida madre, también quedan excluidas las cañas de la naturaleza bucólica que rememora:

¡Oh! ¡cómo palpité...! La fantasía en mágica ilusión mostrome abiertos los campos deliciosos de mi Cuba y entre sus cocoteros ${ }^{113}$ y sus palmas,

\footnotetext{
${ }^{110}$ Alexander von Humboldt realizó dos visitas a la Isla. La primera fue en diciembre de1800, donde permaneció por un período de 4 meses, hasta marzo, y la segunda fue en 1804, antes de embarcarse para los Estados Unidos. Durante las dos décadas siguientes siguió recopilando datos sobre la Isla y recién en 1826 publicó en París el Ensayo político sobre la Isla de Cuba (Essai politique sur l'île de Cuba).

${ }^{111}$ Nótese que todos los énfasis en este fragmento del poema han sido añadidos.

${ }^{112}$ Fragmento del poema Al salto del Niágara (1824), inspirado en una visita que hiciera a las cataratas del Niágara mientras vivía exiliado en los Estados Unidos.
} 
al margen de sus plácidos arroyos, con mi familia cara y mis amigos me hizo vagar. ... $(52-58)^{114}$

A diferencia de Colón y Escobedo, a quienes la naturaleza de la Isla les es extraña, y es a partir de esta extrañeza que describen un paisaje idílico, pero ajeno, los paisajes que Heredia imagina pudieran enmarcarse dentro del paisajismo literario del nacionalismo romántico, entendido el primero como la atracción y fascinación por los paisajes naturales que sintieron los artistas románticos ${ }^{115}$ y el segundo como la expresión artística que toma como modelo la celebración a la patria, al mismo tiempo que sirve para crear una conciencia política nacional ${ }^{116}$. En la mirada de los descubridores europeos predomina la visión de la Isla como botín, de ahí que la abundancia descrita en sus paisajes, más allá del deleite, también tenga un carácter mercantilista y utilitario ${ }^{117}$. En los poemas de Heredia, sin embargo, la construcción del paisaje no es un balance entre el

\footnotetext{
${ }^{113}$ Nótese que todos los énfasis en este fragmento del poema han sido añadidos.

${ }^{114}$ Fragmento del poema Composición poética (1836), escrito durante su exilio en los Estados Unidos.

${ }^{115}$ Esta atracción y fascinación que sintieron los artistas románticos por la naturaleza ha sido tema de estudio en varios trabajos académicos. Ya a mediados del siglo XIX, John Ruskin, en el tercer volumen de su obra Modern Painters (1856), definía de instinto paisajista (landscape-instinct) esta sensibilidad romántica. Según él, los románticos buscaban en los paisajes naturales la belleza que no les podía proporcionar el mundo urbano - asociado a lo feo y a lo falso - y la divinidad que no podían hallar dentro de la crisis espiritual que dominaba la época.
}

\footnotetext{
${ }^{116}$ Esta definición del nacionalismo romántico la he tomado del artículo "Notes Towards a Definition of Romantic Nationalism" (2013) de Joep Leerssen. De todas las definiciones que he leído acerca de este concepto, me parece que ésta logra resumir, de una manera bastante concisa pero acertada, una idea que además de compleja, puede resultar abarcadora. En el texto original se lee: "Romantic nationalism is the celebration of the nation (defined by its language, history, and cultural character) as an inspiring ideal for artistic expression; and the instrumentalization of that expression in ways of raising the political consciousness" (28).

${ }^{117}$ Esta noción del botín americano ha sido analizada por varios académicos, entre ellos Beatriz Pastor (Discursos narrativos de la conquista [1983]) y Fernando Aínsa (De la Edad de Oro al Dorado [1992)]). Según este último, a su llegada a las Américas, en los conquistadores europeos existía una doble visión del mito del oro. El Nuevo Mundo no sólo fue visto como prodigio, un lugar donde se pudiera hallar o construir la perdida Edad de Oro, sino también como botín, una tierra que sirviera como fuente de enriquecimiento.
} 
locus amoenus y el inventario, sino más bien un intento de definir y delimitar la nación a través de sus espacios naturales. La búsqueda de la esencia nacional cubana se refleja en estas descripciones de naturaleza tropical - e insular - edénica que, explicita o implícitamente, se distingue de otros lugares. En A Emilia (1824), también escrito en el destierro, el sentido de pertenencia a una nación como espacio físico de características peculiares —en contraposición a otros espacios — queda reflejado en la comparación que se hace entre ambos paisajes: el del país que lo acoge y el de la lejana y añorada patria. Ante el horizonte oscuro y los campos desolados de un día invernal, evoca Heredia la idealizada tierra natal.

¿Y es ésta la mansión que trocar debo
por los campos de luz ${ }^{118}$, el cielo puro,
la verdura inmortal y eternas flores
y las brisas balsámicas del clima
en que el primero Sol brilló a mis ojos,
entre dulzura y paz ...? (45-50)

En las estrofas que continúan reaparece la alusión a la palma como símbolo de cubanía (55-58), para luego hacer otros contrastes, esta vez, de naturaleza lingüística. Lo curioso en este poema, es que, a pesar de la ausencia de las cañas, sí hay en este fragmento una clara mención —y crítica—a la esclavitud.

$$
\text { [... .] Mi oído, }
$$

en lugar de tu acento regalado, o del eco apacible y cariñoso de mi madre, mi hermana, mis amigas, tan sólo escucha de extranjero idioma los bárbaros sonidos: pero al menos no lo fatiga del tirano infame el clamor insolente, ni el gemido del esclavo infeliz, ni del azote el crujir execrable, que emponzoñan

\footnotetext{
${ }^{118}$ Nótese que todos los énfasis en este fragmento del poema han sido añadidos.
} 
la atmósfera de Cuba. (62-72)

Siguiendo la propuesta del nacionalismo romántico, como el arte que exalta la nación al mismo tiempo que crea conciencia de su esencia (nacional), quizás no sería desacertado sugerir que intenta Heredia en estos versos evocar algo parecido al Volksgeist o espíritu del pueblo. Su manera particular de asociar los paisajes naturales — delimitados dentro del territorio insular - a la patria, al punto de que se conviertan en sinónimo de nación, y de diferenciar y preferir el cariñoso idioma materno a la lengua extranjera y bárbara, responden a la noción de nacionalismo marcado por la identidad geográfica, etnolingüística y cultural, propuesta por algunos de los pensadores que tempranamente influenciaron esta expresión artística, como fueran Jean-Jacques Rousseau (1712-1778), Johann Gottfried Herder (1744-1803) y Johann Gottlieb Fitche (1762-1814), entre otros.

Es interesante apreciar, sin embargo, como en estos tres poemas —escritos desde el exilio- no elige Heredia la caña como símbolo con el cual investir al paisaje de la ideología nacionalista, cuando fue la expansión de la industria azucarera la que le ofreció una dimensión unificadora a la Isla y los campos cubanos de la época, con su infinidad de verdes cañaverales, reflejaron claramente esta transformación. La explicación a esta omisión tal vez se pueda encontrar en la definición de paisajes de la nostalgia ofrecida por Rafael Argullol, en su ensayo La atracción del abismo (1983) —aunque el exilio del poeta, en este caso, le dará una nueva dimensión- $-\mathrm{y}$ en la tesis del concepto de paisaje cultural defendida por Simon Schama en su monumental Landscape and Memory (1995).

Según Argullol el paisaje romántico representa la escisión entre la naturaleza y el hombre, una ruptura que ha propiciado el propio hombre, desde el Renacimiento, con su afán de antropocentrismo. La centralidad procurada en el pasado, una vez alcanzada, 
permitió que el hombre se conociera a sí mismo, pero también manifestó los límites de su poder y, por primera vez, se sintió diminuto, solo e impotente ante el mundo (11-15). La angustia que le produjo este conocimiento generó un apremiante deseo de retorno al Espíritu de la Naturaleza, en un intento por recuperar la mítica Edad de Oro que le devolviera su plenitud (16). La sensibilidad romántica se vuelca entonces en la búsqueda poética de esta perdida naturaleza ideal, o más bien esta nostalgia por un paisaje ideal, que será motivo fundamental en el paisajismo romántico, a pesar de que el hombre romántico está consciente de la imposibilidad del retorno; de ahí que encuentre en la naturaleza goce y melancolía, deleite y terror (42-46).

Una mirada más aguda a los poemas de Heredia pudiera manifestar que, en efecto, sus paisajes, además de evocar símbolos con los cuales identificar la esencia de la nación, también son paisajes de la nostalgia. La descripción bucólica —idealizada— de la naturaleza cubana responde a la búsqueda de este paisaje ideal de los románticos, que se sabe perdido. El exilio, sin embargo, ha propiciado que sea la tierra natal la Edad de Oro que se añora ${ }^{119}$. Cuando Heredia describe los paisajes cubanos, rememora los paisajes de su infancia y su primera juventud, imprimiéndoles su nostalgia, su condición de hombre desterrado a quien se le niega el retorno.

Aunque para Argullol una interpretación bucólica del paisajismo romántico es errónea (17), es importante acentuar que en estos poemas heredianos, a diferencia de otros $^{120}$, es prácticamente imposible no apreciar algunas notas de bucolismo cuando

\footnotetext{
${ }^{119}$ En El Romanticismo: lo romántico en la lírica hispanoamericana (1971), Raimundo Lazo ya hablaba de esta nostalgia que sentía Heredia por la patria, al describirlo como una "especie de caballero andante de la poesía romántica del siglo XIX, cuya Dulcinea se llama[ba] Cuba" (44).

${ }^{120}$ Las descripciones que hace del huracán en el poema En una tempestad (1822), también conocido como
} 
describe a la naturaleza de la patria, a pesar de que la añoranza termine ensombreciendo su placibilidad. En principio, sus versos dedicados a los entornos naturales cubanos se aproximan más a las Églogas de Virgilio que a los fascinantes y desoladores paisajes de Caspar Friedrich $^{121}$, si bien la lejanía de la Isla y la imposibilidad del regreso tienen un peso mayor. La escisión — apuntada por Argullol en su estudio — entre el hombre y la naturaleza en los paisajes románticos, más bien está dada en estos poemas al describir los paisajes extranjeros, a los cuales no pertenece Heredia y con los cuales no logra identificarse sin evitar evocar — nostálgica e idílicamente— los paisajes de su tierra natal.

La naturaleza subjetiva del paisaje herediano observada en estos poemas, que lo aleja del legado neoclasicista de su padre y lo convierte en un precursor del Romanticismo hispanoamericano decimonónico ${ }^{122}$, responde al concepto de paisaje cultural y por ende mnemónico- propuesto por Schama. Según este historiador, al observar el hombre la naturaleza su percepción va a estar plagada de recuerdos, mitos y significados; de ahí que los paisajes, incluso antes de apelar a los sentidos, ya son productos de la mente, contaminados por la cultura (6-7). Como ejemplo, Schama reflexiona en la manera en que en la actualidad el Valle de Yosemite, para él el primer y más famoso Edén americano, es concebido. A pesar de que la mano del hombre ha transformado este lugar — su enorme estacionamiento y los envases de McDonalds son

Oda al huracán, o del mar en Al océano (1936), incluso cuando detalla las cataratas en Al salto del Niágara (1824), ofrecen cuadros más próximos a la ruptura entre la naturaleza y el hombre que, según Argullol, se aprecian en el paisaje romántico.

${ }^{121}$ Caspar David Friedrich (1775-1851) es uno de los pintores paisajistas románticos más reconocidos en la actualidad. Sus majestuosos y desoladores paisajes con figuras humanas casi diminutas todavía siguen cautivando al público, mostrándoles, de alguna manera, el sentir romántico de su época.

${ }^{122}$ Aunque aclamado por la pasión romántica de sus versos, Heredia es un escritor de formación neoclásica y su obra va navegar entre estos dos movimientos. 
testimonio de ello - Yosemite, según Schama, todavía se imagina de la forma que fuera pintado y fotografiado en el siglo XIX, sin rastro de la presencia humana. Para él, sin embargo, esta primera imagen impoluta del Valle también es imaginaria, ya que el propio acto de identificar y fotografiar el lugar presupone la huella del hombre y con él todo su bagaje cultural $^{123}(7)$. Basado en esta tesis se pudiera concluir que toda naturaleza observada por el hombre deja ser real y pura, para convertirse en paisaje, siempre imaginario y contaminado por la cultura.

Siguiendo esta definición, no sería difícil argumentar que los paisajes que Heredia evoca en estos poemas no son una réplica exacta de la naturaleza observada, sino más bien un constructo de su imaginación plagado por sus experiencias y concepciones culturales. A ello habría que adicionarle la doble naturaleza imaginaria —mnemónica y selectiva- de su representación paisajística, si se tiene en cuenta que estos paisajes fueron doblemente reproducidos: cuando se percibieron por primera vez en la Isla y cuando fueron recordados desde el exilio. La patria rememorada, ese Edén perdido que se añora, no responde entonces a la nación real, sino más bien a la que Heredia, lejos de ella, imagina. En esta imagen, sin embargo, la ausencia de las cañas en sus paisajes, como símbolo de la identidad nacional, se hace notar.

Aunque es difícil de precisar con exactitud el motivo por el cual Heredia excluyó a las cañas en estos tres poemas, y existe la posibilidad de que aquellos panoramas de su infancia y su primera juventud no estuvieran contaminados por los verdes cañaverales -

\footnotetext{
${ }^{123}$ En el texto original al inglés se lee: "Take the first and most famous American Eden: Yosemite. Though the parking is almost as big as the park and there are bears rooting among the McDonald's cartons, we still imagine Yosemite the way Albert Bierstadt painted or Carleton Watkins and Ansel Adams photographed it: with no trace of human presence. But off course the very act of identifying (not to mention photographing) the place presupposes our presence, and along with us all the heavy cultural backpacks that we lug with us on the trail" (7).
} 
téngase en cuenta que la expansión azucarera se demoró en llegar a su Oriente natal y que fueron más los años que vivió en tierras extranjeras que en su propia patria ${ }^{124}$-, me atrevo a argumentar que en su crítica a la esclavitud puede estar la clave de la exclusión de las cañas dentro de la simbología poética con la que imagina a la patria. Tanto en $A$ Emilia (1824), como en Himno del desterrado (1825) —uno de sus poemas más famosos, también escrito en el exilio - el deleite que produce la rememoración del paisaje natural cubano y de sus personas queridas, aquel paisaje ideal que perseguían los románticos, es ensombrecido por el recuerdo de la esclavitud. En el primero confiesa que, aunque sus ojos no verán ya mecerse la copa de la palma, ni sus oídos escucharan el eco de su madre y sus hermanas, al menos no tendrá que escuchar el gemido del esclavo infeliz (5570) ${ }^{125}$. En el segundo, por su parte, la conjunción y ruptura entre estas dos imágenes —el paisaje ideal y el horror de la esclavitud — es mucho más evidente.

¿Ya que importa que al cielo te tiendas, de verdura perenne vestida, y la frente de palmas $^{126}$ ceñida a los besos ofrezcas del mar, si el clamor del tirano insolente, del esclavo el gemir lastimoso, y el crujir del azote horroroso se oye sólo en tus campos sonar? (56-63)

\footnotetext{
${ }^{124}$ Heredia nació en Santiago de Cuba, ciudad al oriente de Cuba, en 1803. Debido a la carrera de su padre, alterna su niñez y su primera juventud entre Santo Domingo, Caracas, México y Cuba, adonde regresa al morir su padre en 1820. Tres años más tarde, por cuestiones políticas, se exilia en los Estados Unidos y en 1825 emprende otro viaje a México. En 1836 obtiene permiso para regresar a Cuba, pero después de unos meses se ve forzado a retornar una vez más a México donde muere en 1839.

${ }^{125}$ Como la segunda parte de este fragmento ya fue reproducido en páginas anteriores (versos 62-72), reproduzco en esta nota los versos que pertenecen a la primera (versos 55-62): “... Mis ojos doloridos/ no verán ya mecerse de la palma/ la copa gallardísima, dorada/ por los rayos del Sol en occidente;/ ni a la sombra de plátano sonante/ el ardor burlaré de mediodía,/ inundando mi faz la frescura/ que respira el blando céfiro."

${ }^{126}$ Nótese que todos los énfasis en este fragmento del poema han sido añadidos.
} 
Si las palmas y demás elementos de la naturaleza, como son los cocoteros, las flores y los arroyos, entre otros, son figuras que dentro del paisaje nostálgico le producen goce y un sentido de seguridad y pertenencia al poeta —el retorno al Edén perdido, a la naturaleza inmaculada, que en Heredia es sinónimo de patria - la esclavitud, y por asociación las cañas, son parte del horror mundano del cual el hombre romántico quiere escapar. Los verdes cañaverales asociados en Cuba a la servidumbre del negro, a la africanización de la cultura y a la expansión azucarera —equivalente en la Isla a la industrialización ${ }^{127}$ - romperían con la escena ideal, bucólica y escapista, que el poeta, en su condición de exiliado, inventa. Heredia, como romántico, quiere regresar a través de la naturaleza a una edad primigenia no contaminada por la civilización, lo cual presupone un acto consciente de idealización del paisaje, donde se pretende eliminar todo vestigio del ser humano que no esté en fusión con la naturaleza silvestre. Heredia, como cubano, cuando piensa en el retorno visualiza a la patria, una patria sin cañaverales y sin negros esclavos, algo que en el siglo XIX cubano implicaba una problemática, porque equivalía a un país sin azúcar. Estos versos, al excluir a la gramínea dentro del paisaje nacional, fueron tal vez de los primeros escritos literarios en presentar esta disyuntiva. Más adelante aparecerán otros textos, que, de una manera mucho más clara y amplia, reflejarán el conflicto entre el negro, el azúcar y la nación imaginada.

\footnotetext{
${ }^{127}$ Aunque no se produce una revolución industrial al estilo europeo - el trabajo esclavo no lo permitíala expansión de la agroindustria azucarera, con los nuevos ingenios y extensos cañaverales, pero sobre todo, con la construcción de un ferrocarril en 1837, destinado al transporte de azúcar y melaza, es sinónimo en Cuba de la industrialización. Sobre este tema indagaré más adelante en el acápite donde analizo la obra Los ingenios (1857). Para más información sobre los avances tecnológicos relacionados a la industria azucarera que fueron implementados en la Isla durante el siglo XIX, puede consultar el acápite "El crecimiento de la producción de azúcar, c. 1860- c. 1900" de la obra El ingenio de Moreno Fraginals.
} 


\subsection{LOS PAISAJES AZUCAREROS EN LA NOVELA ANTIESCLAVISTA}

DECIMONÓNICA: ESPACIOS RACIALIZADOS POBLADOS DE MONSTRUOS EN LAS MÁRGENES DE LA NACIÓN

Al calesero se le amenaza con el cafetal, al que trabaja en el cafetal se le amenaza con el ingenio de azúcar. En éste el negro que tiene mujer, que vive en cabaña separada. . encuentra después del trabajo quien le cuide ... tiene una suerte que no se puede comparar al esclavo aislado y perdido en la multitud. Alexander Von Humbolt

Y cual demonio con furor danzaban/. . las espaldas desnudas y encorvadas/ Semejantes a lomos de panteras/cubiertas de sudor, brillar se veían;/ de rabioso placer, las torpes hembras;/abrazaban frenéticas el cuello/ del esposo feroz que la empujaba,/dando un brinco salvajel para agarrarse a la mujer ajena...

Úrsula Céspedes

A diferencia de los poemas de Heredia analizados en el acápite anterior, donde los verdes cañaverales son excluidos del paisaje natural cubano, en la novela antiesclavista Sab (1841), de Gertrudis Gómez de Avellaneda (1814-1873), la caña de azúcar sí forma parte de los elementos naturales que conforman los campos de la Isla. A pesar de esta inclusión, o más bien gracias a ella, el análisis de los diferentes paisajes que aparecen en esta obra pudiera secundar la idea de que, en efecto, en la literatura cubana de la época la representación del azúcar era problemática. Ya en las primeras páginas de la novela existe una ruptura entre el pintoresco paisaje que celebra la naturaleza cubana y el paisaje azucarero que se valora por su utilidad. En el primero abundan descripciones de la flora y de la fauna de la región, especialmente de aves, además de que también se detallan otros elementos relacionados al clima.

El Sol terrible de la zona tórrida se acercaba a su ocaso entre ondeantes nubes de púrpura y de plata, y sus últimos rayos, ya tibios y pálidos, vestían de un colorido melancólico los campos vírgenes de aquella joven 
naturaleza, cuya vigorosa y lozana vegetación parecía acoger con regocijo la brisa apacible de la tarde, que comenzaba a agitar las copas frondosas de los árboles agostados por el calor del día. Bandadas de golondrinas se cruzaban en todas direcciones buscando su albergue nocturno, y el verde papagayo con sus franjas de oro y de grana, el cao de un negro nítido y brillante, el carpintero real de férrea lengua y matizado plumaje, la alegre guacamalla ( $\mathrm{sic}$ ), el ligero tomeguín, la tornasolada mariposa y otra infinidad de aves indígenas se posaban en las ramas del tamarindo y del mango aromático ...

El viajero después de haber atravesado sabanas inmensas . . . y prados Coronados de palmas y gigantes ceibas, tocaba por fin en un cercado, anuncio de propiedad. (10-11)

A diferencia de esta primera descripción del campo cubano, donde se resalta la exuberancia de la naturaleza tropical en un afán de hallar la esencia de la nación, la primera mención que se hace a las cañas en esta obra —en un diálogo entre el esclavo Sab y el comerciante inglés Enrique Otway ${ }^{128}$ — es para dar una relación del rendimiento de su industria y para describir el trato inhumano que recibían los esclavos que participaban en la producción del azúcar.

Enrique: Esta finca debe producir ${ }^{129}$ mucho a su dueño.

Sab: Tiempos ha habido, según he llegado a entender — dijo el labriego deteniéndose para echar una ojeada hacia las tierras objeto de la conversación-, en que este ingenio daba a su dueño doce mil arrobas de azúcar cada año, porque entonces más de cien negros trabajaban en sus cañaverales; pero los tiempos han variado y el propietario actual de Bellavista no tiene en él sino cincuenta negros, ni excede su Zafra de seis mil panes de azúcar.

Enrique: Vida muy fatigosa deben tener los esclavos en estas fincas.

Sab: Es una vida terrible a la verdad ... bajo este cielo de fuego el esclavo casi desnudo trabaja toda la mañana sin descanso, y a la hora terrible del mediodía jadeando, abrumado bajo el peso de la leña y de la caña que conduce sobre sus espaldas, y abrasado por los rayos del Sol que tuesta su cutis, llega el infeliz a gozar todos los placeres que tiene para él la vida: dos horas de sueño y una escaza ración. Cuando la noche viene con sus brisas y sus sombras a consolar a la tierra abrasada, y toda la naturaleza descansa, el esclavo va a regar con su sudor y con sus lágrimas al recinto

\footnotetext{
${ }^{128}$ Enrique Otway es el prometido de Carlota, el ama de Sab.

${ }^{129}$ Nótese que todos los énfasis en este fragmento han sido añadidos.
} 
donde la noche no tiene sombras, ni la brisa frescura: porque allí el fuego de la leña ha sustituido al fuego del Sol, y el infeliz negro girando sin cesar en torno de la máquina que arranca a la caña su dulce jugo, y de las calderas de metal en las que este jugo se convierte en miel a la acción del fuego, ve pasar horas tras horas, y el Sol que torna le encuentra todavía allí. (12-13)

Si en el primer paisaje las plantas, las aves, sus diversos colores, y demás elementos naturales celebran la naturaleza de la Isla convirtiéndose en signos de identidad — figuras con las cuales se define y distingue la patria—, en el diálogo reproducido en las líneas anteriores la caña se convierte en un símbolo de la esclavitud y de la industrialización. El uno es un indudable paisaje natural donde a la naturaleza, aunque contaminada por la mirada del hombre, se le imprime la cualidad divina y purificadora que en ella buscaban los románticos. El otro, en cambio, a través de la descripción detallada de las condiciones inhumanas en las que trabajaban los esclavos durante el proceso industrial del azúcar — desde el corte de la caña hasta la producción de la miel—, se aleja del Espíritu de la naturaleza para adentrarse en el mundo de la máquina, transformándose, de esta manera, en el aborrecido paisaje industrial del que tanto huía el hombre romántico de la época.

Otro ejemplo evidente de la ruptura entre el paisaje natural y el paisaje azucarero se puede apreciar en la escena donde se describe el jardín que Sab había cultivado para Carlota. En este pequeño recinto, descrito como el cuadro perfecto, el esclavo había reunido todas las flores que le gustaban a su ama, además de que había construido un pequeño estanque con peces de colores (44). Carlota acudía a él y se deleitaba disfrutando de la naturaleza, ya sea recogiendo flores, persiguiendo mariposas o, incluso, sentada pensativa al borde del estanque. Al igual que en los poemas de Heredia donde la 
caña de azúcar no es uno de los elementos que conforman el paisaje y donde el recuerdo de la esclavitud irrumpe el disfrute de la naturaleza, en el jardín idílico de Carlota no había cañas ${ }^{130}$ y el bullicio de algunos esclavos que se dirigían al trabajo interrumpe, en esta escena, las inocentes distracciones de la joven (45). La sombra del paisaje azucarero, los cañaverales o la fábrica hacia la que acudían los esclavos, ensombrecía el paisaje imaginario de los románticos, un mundo donde no tenía cabida ni la máquina, ni el negro esclavo.

Además de esta asociación de la caña de azúcar al trabajo esclavo y a la producción azucarera, es importante destacar que los cañaverales son en esta obra lugares físicos -y simbólicos — relacionados al mundo negro, donde el hombre blanco apenas tiene cabida. Allí en los cañaverales es donde Sab, el esclavo mulato, va a refugiarse avergonzado cuando siente que Teresa ha descubierto su amor por Carlota; mientras que ésta, al sentir que el esclavo se ha percatado de sus sentimientos hacia Enrique, huye a su habitación ${ }^{131}(55)$. También cerca de los cañaverales es donde Sab le da cita a Teresa para que hablen, lejos de la mirada de los otros, sobre sus destinos (83-84). Aunque en la novela hay varios fragmentos donde se detalla la naturaleza, y en diversas ocasiones se menciona la caña con relación a la industria y a la esclavitud, este encuentro secreto entre Teresa y Sab es el único episodio donde los cañaverales forman parte del paisaje natural que se describe y donde un personaje blanco visita el lugar. Es significativo, sin embargo,

\footnotetext{
${ }^{130}$ Según la descripción, el jardín estaba protegido por hileras de cañas conocidas como pitos, que en Cuba es un nombre con el que se denomina a la caña brava o bambú, gramínea silvestre que no debe confundirse con la caña de azúcar.

${ }^{131}$ En el fragmento se lee: "Se han entendido y huye cada uno de las miradas del otro. Sab se interna por los cañaverales, corriendo como el venado herido que huye del cazador llevando ya clavado el hierro en lo más sensible de sus entrañas. Teresa se encierra en su habitación" (55).
} 
que sea Sab, un esclavo, quien convoque a Teresa detrás de los cañaverales y que ésta sólo acceda debido a su insistencia, no sin antes haber mostrado cierto temor.

Sab: ... Esta noche, cuando el reloj que hace un momento mirabais, haya sonado las doce, os aguardo en las orillas del río a espaldas de los cañaverales del Sur.

Teresa: ¡A las doce! ¡Sola! ¡Tan distante!

Sab: ¡Y qué! ¿Tendréis miedo del pobre mulato a quien creísteis digno de recibir de vos el retrato de Carlota? ¿Me tendréis miedo, Teresa?

Teresa: No —respondió ella con voz más segura-: ¡Sab! Yo te lo prometo, acudiré a la cita. (83-84)

Del diálogo entre estos dos personajes se desprende que este lugar tiene una significación distinta para ambos. El esclavo ve en los cañaverales su refugio, el lugar donde acudir cuando lo atormenta alguna pena, donde puede expresar sus sentimientos, aunque sean innobles, y meditar acerca de su vida sin temor. Para Teresa, en cambio, los cañaverales son un lugar remoto y prácticamente desconocido, donde le puede acechar algún peligro si acude al encuentro de Sab. El uno halla entre las cañas consuelo, la fuerza para confesar el amor que siente por su ama; el otro, sin embargo, sospecha que entre ellas puede encontrar el horror. Los cañaverales se convierten entonces en la morada segura del esclavo - analogía del mundo negro y la africanización-, un espacio al cual el hombre blanco no pertenece, pero, sobre todo, un lugar donde se materializa su temor a la negritud. Allí, en los cañaverales, se siente indefenso, a la medida que el negro recobra su subjetividad.

Esta doble percepción del paisaje azucarero, como refugio del negro que tanto horroriza al blanco, no debe sorprender, sin embargo, si se tiene en cuenta que en los ingenios decimonónicos existía una división entre las áreas residenciales, habitadas y frecuentadas por los propietarios, y las zonas agroindustriales, relacionadas a la 
producción azucarera y a la gran masa de esclavos. A las primeras, conformadas por la residencia, los jardines y otras edificaciones, además de los dueños y sus familiares, sólo tenían acceso, por lo general, los esclavos domésticos de confianza. Mientras que en las segundas, constituidas por la fábrica, los sembrados de caña, los barracones o bohíos de esclavos, entre otras, se va a concentrar, junto a algunos técnicos y trabajadores asalariados, la dotación de esclavos involucrados a la producción. El ingenio, se pudiera concluir, reproducía de cierta manera las jerarquías sociales existentes en la sociedad una pirámide del poder en palabras de Foucault-, cuyo vértice y cuya base constituían dos universos: el pretendido inmaculado mundo de los blancos, donde los esclavos domesticados, conteniendo su herencia africana, imitaban las costumbres impuestas por sus amos ${ }^{132}$; y el mundo de los negros, donde, a pesar de las largas horas de trabajo y la férrea vigilancia del mayoral, las diferentes prácticas culturales de los esclavos se perpetuaban. El uno era el centro, lugar en que las jerarquías y leyes funcionaban según los estatutos de la sociedad esclavista: un propietario que impone sus deseos y costumbres a un esclavo que obedece, teme y calla; mientras que el otro, incluyendo los grandes cañaverales, se transformaba, para los blancos, en un lugar periférico, extraño y cerrado. Allí era él el extranjero, en un universo negro que consideraba bárbaro.

Cuando Teresa reclama, asustada, que el sitio del encuentro es muy distante, más allá de la distancia física, también hay una distancia basada en el temor a un mundo que para ella es insólito y donde siente su vida puede peligrar. Aunque no se mencione explícitamente en este diálogo, los ecos de la africanización de la cultura y de una posible

\footnotetext{
${ }^{132}$ Un ejemplo de cómo los esclavos a veces imitaban el comportamiento de su amos se puede encontrar en la novela Cecilia Valdés. En ella la esclava Dolores se esforzaba por identificarse con su ama y hermana de leche Adela. Imitaba su tono de voz, su manera de andar y de llevar el traje, por lo que los otros esclavos cuando querían halagarla la llamaban Niña Adela (307).
} 
sublevación de esclavos son los que fundan su temor; de ahí que Sab, consciente del miedo blanco, le pregunte si acaso temería un encuentro con él en aquel lugar. La pregunta, aunque en principio puede sorprender, valida la tesis de que el espacio ha adquirido cierta significación que va más allá de su lejanía física. ¿Por qué tendría que temerle Teresa a Sab, cuando en el pasado ha confiado en él? ¿Qué puede haber de peligroso en un encuentro con el esclavo fiel, a quien justamente recién se le ha otorgado la libertad debido a su lealtad e intachable conducta hacia sus amos? La respuesta a estas preguntas se halla justamente en el espacio que ha elegido Sab para el encuentro, un lugar destinado a la negritud, donde el legado africano del mulato se libera y exterioriza, cobrando cierto poder.

Retomando la idea de que la arquitectura del ingenio reproduce las jerarquías sociales, en un intento de demarcar y aislar la cúspide — centro del poder- del resto de la pirámide, pero, sobre todo, de su base, es posible argumentar que con esta técnica arquitectónica se crean lo que David Theo Goldberg, en su obra Racist Culture (1993), denominara espacios racializados. Según Goldberg, las diferentes categorías del espacio social, producidas y ordenadas a través del discurso, se conciben y estructuran no sólo teniendo en cuenta las definiciones de género y clase, sino también las categorías raciales (185). De esta manera, a los diferentes grupos raciales se les destinan espacios específicos dentro de la comunidad. Piénsese, a nivel de la sociedad estadounidense actual, en la distinción entre el llamado gueto negro americano y un barrio residencial de clase media blanca o, como ejemplificara Goldberg en su obra, en el espacio apartheid sudafricano, donde la segregación racial llega a los extremos. A nivel global, tomando otro de los ejemplos que ofrece este catedrático en su estudio, se puede considerar las 
distinciones entre el Occidente y el Oriente y lo que implican estas categorías geográficas más allá de la mera geografía (185).

Con la institución de estos espacios racializados, con los que según Goldberg se organiza el mundo y el hombre se disciplina, se crea, en su opinión, una dicotomía entre un lugar hegemónico, entendido como centro, y los espacios que quedan en las márgenes. Aunque no siempre correspondan a la distinción geográfica que se les atribuye ténganse en cuenta que en ocasiones los espacios físicamente periféricos han sido codiciados por los grupos raciales favorecidos ${ }^{133}$-, el centro se asocia al bienestar, a la seguridad, a la certidumbre, pero, sobre todo, al poder; mientras que las márgenes sugieren la escasez, la inseguridad, lo extraño, lugares que implican inferioridad y subordinación. Los unos constituyen los centros hegemónicos del poder y el orden, mientras que los otros representan los espacios marginalizados, asociados a la indigencia y a la degeneración, márgenes anárquicos que deberían ser evitados (186-188).

En el caso específico de las colonias, la administración colonial se encargaba de crear estos espacios racializados que mantenían una división entre los europeos y los nativos. En lugares como Cuba, donde la trata de negros esclavos fue la solución que hallara el gobierno ante la escasez de brazos — tras la casi total extinción de la población aborigen-, la división era dada mayormente entre los europeos y sus descendientes blancos criollos- y la población africana y afrodescendiente, tanto esclava como libre. En una ciudad como La Habana, si se tomase de ejemplo, arquitectónicamente había una

\footnotetext{
${ }^{133}$ En la obra Goldberg pone como ejemplo la categoría hegemónica que adquirieron los llamados suburbs americanos en las décadas de los años 60 y 70 . Estos barrios residenciales, justamente por estar ubicados a las afueras de la ciudad - dentro de la que se encontraban los espacios industriales y los barrios más pobres - se convirtieron en símbolo de bienestar y eran extremadamente codiciados por la clase media blanca americana (188).
} 
división entre lo que sería el centro amurallado y los llamados barrios de extramuros, asociados a lo extraño, a lo monstruoso y al entretenimiento impío ${ }^{134}$, algo que Jorge Camacho examina en su estudio "Los monstruos de la periferia" "135, analizando algunas crónicas de José Victoriano Betancourt (1813-1875) y Francisco Calcagno (1827-1903).

Este tipo de fragmentación espacial también se puede advertir claramente en otras obras de corte romántico y/o costumbrista de la época, como fuera la afamada novela Cecilia Valdés (1882) ${ }^{136}$ de Cirilo Villaverde (1812-1894). En ella, Villaverde le destina a cada grupo racial un lugar de pertenencia. Existe una marcada diferencia entre el vecindario del callejón de San Juan de Dios donde vivía Cecilia, sinónimo de negritud y pobreza, y el barrio de San Francisco donde se hallaba la residencia de la familia Gamboa, asociado a las familias blancas adineradas.

En cuanto a los espacios de placer y entretenimiento, durante las ferias que se realizaban a finales de septiembre como parte de las fiestas titulares religiosas ${ }^{137}$, la muchedumbre, en su mayoría gente de color y de la peor ralea —en palabras de Villaverde-, asistía a los juegos que se efectuaban en la plazuela o en la calle, mientras que los integrantes de la alta sociedad aficionados al juego acudían a las casas de bailes que se alquilaban para tales eventos (91). Incluso en los bailes organizados por las clases

\footnotetext{
${ }^{134}$ Hay que entender que en una sociedad conservadora y católica como la Cuba del siglo XIX el entretenimiento podía estar vinculado al pecado y a la impureza.

${ }^{135}$ Me refiero al capítulo II de su obra Miedo Negro, poder blanco en la Cuba colonial (2015), titulado "Los monstruos de la periferia: los personajes de José Victoriano Betancourt".

${ }^{136}$ Aunque tomo como fecha de publicación el año en que se publica la versión definitiva de esta novela, se debe tener en cuenta que la novela abarca el período histórico comprendido entre 1812 y 1831 .

${ }^{137}$ Nótese que en la novela Villaverde dice que las festividades se habían iniciado a finales de septiembre, pero al tratarse de las Ferias del Ángel, estas celebraciones no concluirían hasta el 24 de octubre en conmemoración a San Rafael.
} 
bajas — conocidos como cuna-, a los cuales además de negros y mulatos de ambos sexos también acudían jóvenes blancos de familias decentes y acomodadas, existía lo que Villaverde llamara una línea divisoria entre los hombres de ambos grupos raciales (109). En la residencia de Mercedes Ayala, mulata rica que en conmemoración a su cumpleaños de santo celebrara uno de estos bailes, los blancos permanecían en el comedor y en el aposento principal de la casa y sólo allí, justamente para mantener dentro de lo posible la línea de separación, bailaban con sus mulatas $(109,114)$. Estos espacios fronterizos, donde según Villaverde olvidaban los hombres momentáneamente los celos y el odio mutuo que se profesaban (109) y donde evidentemente era más profunda la transculturación de la sociedad cubana, a pesar de escapar de las rígidas convenciones impuestas por la clase blanca dominante, todavía eran ensombrecidos por las jerarquías sociales - raciales - imperantes.

En contraposición a estos espacios ambivalentes que ofrecían las cunas, Villaverde describe el baile que organizaba la Sociedad Filarmónica durante estas festividades, en un palacio que era alquilado para tal ocasión. Mientras que en el primero ambos grupos raciales podían relacionarse y beber de sus culturas de una manera más dinámica, convirtiéndose para el joven blanco que lo concurría en un lugar emancipador, en el segundo, al cual sólo eran invitados los miembros de la alta sociedad — blanca一, no se podía escapar de la mirada escrutadora de los salvaguardas de la moral y las buenas costumbres. En él Leonardo y sus amigos cortejaban a las señoritas de su clase económica y racial— siguiendo las pautas impuestas por la sociedad ${ }^{138}$. El baile

\footnotetext{
${ }^{138}$ El capítulo 3 de la segunda parte está dedicado enteramente a detallar los pormenores de este baile organizado por la Sociedad Filarmónica para los miembros de la alta sociedad (222-234).
} 
palaciego funcionaba entonces como un espacio racializado, para los blancos, que se entendía como hegemónico, centro del poder. En la cuna, sin embargo, el comisario Cantalapiedra toma como pareja de baile a Mercedes Ayala, mientras que Leonardo y su amigo Diego Meneses invitan a Cecilia y a Nemesia (114). El lugar, aunque perteneciente a las márgenes —asociadas a la extrañeza, a la indigencia y a la degeneración - adquiere ahora una connotación liberadora, al poder bailar los blancos con sus mulatas; algo que en su estudio Goldberg, al definir espacios similares, atribuye a la posibilidad que ofrecían estos lugares de escapar de la fobia producida por el confinamiento del espacio cerrado o central (186). No obstante, el hecho de que existiera un línea divisoria en este lugar, donde justamente las férreas disciplinas sociales se resquebrajaban, evidencia que la Cuba decimonónica se concebía de una manera racializada, concepción que terminó influyendo su paisajismo literario.

Si durante los primeros capítulos Villaverde se concentra en la vida en la ciudad, en los espacios urbanos, en la tercera parte de la novela la acción se va a desarrollar mayormente en el campo y los paisajes naturales pasaran a cobrar gran importancia. Aquí, al igual que en los poemas de Heredia y la novela de Avellaneda, hay un intento por definir la nación a través de sus espacios naturales y hay una marcada diferencia entre el paisaje natural, exuberante y deleitoso — ese locus amoenus cargado de cubanía—y el paisaje azucarero, estigmatizado por la esclavitud y la industrialización.

En los primeros capítulos de esta tercera parte Villaverde describe los paisajes de una región al occidente de la Isla conocida como Vuelta Abajo ${ }^{139}$. Estas páginas se

\footnotetext{
${ }^{139}$ Vuelta Abajo es un territorio montañoso de la parte occidental de Cuba, en la actual provincia de Pinar del Río, donde a finales del siglo XVIII y principios del siglo XIX hubo un gran auge de la plantación esclavista.
} 
enmarcan claramente dentro del paisajismo literario del nacionalismo romántico, dentro del afán por descubrir y determinar lo cubano a través de la definición de sus espacios. A los conocedores de la obra de Villaverde no les será difícil vincular las descripciones de estos paisajes a Excursión a Vuelta Abajo ${ }^{140}$, relato de viaje en dos tomos escrito por el propio autor, que fuera definido por Benítez Rojo como uno de los textos fundadores de la cubanía ("Cirilo Villaverde", 769), o a la Advertencia que escribiera Villaverde en Diario del rancheador ${ }^{141}$. El recorrido descrito en estos capítulos comprende el camino hacia el ingenio La Tinaja, propiedad de la familia Gamboa, pasando primeramente por el cafetal La Luz, cuya propietaria fuera Isabel Ilincheta, la prometida de Leonardo. En la primera parte del trayecto ${ }^{142}$ predominan los cafetales y aunque Villaverde menciona que el cultivo general ha ahuyentado algunas especies de pájaros (392), describe esta región como el famoso jardín de Cuba: tierras donde "no se fundaban entonces [. . .] granjas para la explotación agronómica, en el sentido estricto de la palabra, sino verdaderos jardines para la recreación de sus sibaritas propietarios, mientras se mantuvo alto el precio del café" (392). La explotación cafetalera ${ }^{143}$, según estos párrafos, tanto de la tierra como del esclavo que trabaja en la producción del café, es mínima comparada con la agroindustria azucarera y la masa de esclavos que ésta produce. La clara postura que

\footnotetext{
${ }^{140}$ Excursión a Vuelta Abajo comprende la narración de dos viajes a esta región hechos por Villaverde. El primer relato fue publicado en El Álbum en 1938 y el segundo en el Faro Industrial de La Habana en 1842. Ambos textos fueron copilados por Villaverde en 1891 (Benítez Rojo, "Cirilo Villaverde, fundador").

${ }^{141}$ Diario del rancheador (1843) es la transcripción que hiciera Villaverde del diario de Francisco Estévez, uno de los rancheadores nombrados por la Real Junta de Fomento y Consulado de La Habana para patrullar las montañas de Vuelta Abajo en busca de negros cimarrones.

${ }^{142}$ Esta primera parte del trayecto corresponde al primer capítulo de la tercera parte de la novela.

${ }^{143}$ En una cita que incluyo más adelante se puede apreciar que la producción del tabaco también es favorecida por Villaverde. Su oposición era, evidentemente, a la majestuosa agroindustria azucarera que iba, poco a poco, tragándose otros cultivos.
} 
mantiene Villaverde en estas páginas a favor de la llamada Cuba Pequeña se trasluce en unos propietarios benévolos cuyo trato a sus esclavos se aproxima más al paternalismo, que a la inhumana sujeción propia de la esclavitud, de ahí que Isabel sea descrita como la dueña cariñosa y blanda de esclavos sumisos que la lloran a su partida del cafetal (417419). Por otra parte, la posición de Villaverde a favor de la Cuba preazucarera también se vislumbra en la descripción de un paisaje exuberante y placentero, depositorio de lo cubano, donde una vez más la palma $-\mathrm{y}$ no la caña — resalta como símbolo por excelencia de la cubanía:

como que crecía ahí más frondoso el naranjo de globos de oro, el limonero indígena y exótico, el mango y la manga de la India, el árbol del pan, de ancha hoja; el ciruelo de varias especies, el copudo tamarindo de ácidas vainas, el guanábano de fruta acorazonada y dulcísima, la gallarda palma, en fin, notable entre la gran familia vegetal por su tronco recto, cilíndrico, liso y grueso como el fuste de una columna dórica, y por el hermoso cerco de pencas con que se corona perennemente. (393)

La descripción de estos paisajes nacionales paradisíacos, también predominante en el segundo capítulo de esta tercera parte y en parte del tercero, cesa abruptamente, sin embargo, según los viajeros se van acercando a la zona azucarera donde se encuentra el ingenio La Tinaja. Ocurre aquí una clara escisión en el paisaje que deja de estar impregnado de cubanía para convertirse en una tierra extraña.

No hay paridad ninguna en la fisonomía del país visto por ambos lados de las montañas. Por el Sur, la llanura con sus cafetales, dehesas y plantaciones del tabaco, continúa casi hasta el extremo de la isla y es lo más ameno y risueño que puede imaginarse. Al contrario por el lado del Norte, en el mismo paralelo se ofrece tan hondo, áspero y lúgubre a las miradas del viajero que cree pisar otra tierra y otro clima. Ni porque está ahora cultivado en su mayor parte hasta más allá de Bahíahonda, se desvanece esa mala impresión. Quizá porque sus labranzas son ingenios azucareros, porque el clima es sin duda más húmedo y cálido, porque el suelo es negro y barroso, porque la atmosfera es más pesada, porque el hombre y la bestia se hallan allí más oprimidos y maltratados que en otro 
parte de la Isla, a su aspecto sólo la admiración se trueca luego en disgusto y la alegría en lástima. (423)

Con estas palabras divide Villaverde la región de Vuelta Abajo en dos territorios diferentes y antagónicos. El uno, con sus cafetales y vegas de tabaco, forma parte del paisaje natural que el viajero, a su paso, va descubriendo e incorporando al discurso fundador de la nación. Mientras que el otro, con sus cañaverales e ingenios azucareros, le produce una extrañeza. A diferencia de la zona antes descrita, no se identifica Villaverde con esta masa de tierra al norte de la región, plagada de plantaciones de cañas, fábricas de azúcar y negros esclavos, dejando al descubierto un latente deseo por eliminar estos paisajes azucareros del imaginado territorio nacional. Hay en estas líneas una crítica implícita a la industria azucarera y a la sacarocracia. El paisaje refleja una postura antiesclavista y anti-azúcar, una aversión a la máquina y al cañaveral, pero también al negro, que pronto se relacionará al mundo de la muerte y de lo monstruoso. Por otra parte, el paisaje también funciona como una imagen premonitoria de lo que será, a partir de este momento, una experiencia horrorosa y traumática para los personajes que no conocían la vida en los ingenios azucareros.

Al adentrarse los viajeros en esta región extraña, bordeando o atravesando los grandes ingenios, se entra en un mundo donde la producción agroindustrial del azúcar irrumpe la pasividad y deleite de los campos. La primera escena corresponde a la molienda y cocción de la caña en el ingenio de Zayas, propiedad por donde transitan camino al ingenio La Tinaja. El vocerío y movimiento de los hombres y los animales, el látigo del mayoral, el azote que los esclavos le proporcionan a las mulas, el estrepitoso ruido del trapiche y el denso humo de las hirvientes calderas (427-428) hacen del ingenio 
un lugar infernal donde pareciera que la monstruosa máquina — símbolo de la industria azucarera—, con su voracidad, fuera devorándolo todo: al hombre, a la bestia y a la caña — preludio a parte de la literatura del azúcar del siglo XX que se centra en la capacidad destructora de esta industria-.

Luego de esta primera escena industrial, que evidencia la idea de que se ha traspasado a un mundo diferente, se suceden escenas cada vez más perturbadoras. A diferencia de la experiencia en el cafetal La Luz, donde al parecer los esclavos y sus amos vivían en una especie de armonía, recién llegados al ingenio La Tinaja se percibe la hostilidad entre ambos grupos socio-raciales. Justo a la entrada del ingenio Leonardo intenta golpear al negro guardiero, después de haberle gritado una serie de improperios, por no haber estado esperándolos, a él y a sus invitados, para abrirles la talanquera (432434). Más tarde se tiene noticia de que han capturado a uno de los esclavos cimarrones ${ }^{144}$ que se habían dado a la fuga hacía algunos días y lo tienen en la enfermería por graves mordidas producidas por los perros (452). Otro par esclavos, también cimarrones, que tras la captura de éste deciden entregarse y pedir perdón, no se escapan de la ira del látigo del mayoral (468-470). El maltrato a los esclavos, lejos de ser un acto ocasional, era, en este ingenio, el pan de cada día.

Todos estos episodios de alguna manera van impregnando el paisaje azucarero, ya no de la anhelada cubanía, sino de símbolos relacionados al sufrimiento esclavo, a la crueldad blanca y también, como se verá más adelante, a la monstruosidad negra. Como prueba de ello se puede tomar el fragmento donde se describe una cabalgata que dieran

\footnotetext{
${ }^{144}$ Debido a que algunas zonas de Vuelta Abajo eran muy abruptas, la atravesaban varios ríos y la azotaban largos períodos de lluvia, el cimarronaje era muy común en esta región. En la novela es justamente la partida de ranchadores de Francisco Estévez (ver nota 141) la que se encarga de rastrear a este grupo de esclavos cimarrones.
} 
los invitados junto a Leonardo por las tierras del ingenio. Lo que en principio resulta un paseo placentero por los campos, que le devuelven a Isabel "las rosas a sus mejillas, el fuego a sus ojos y la sonrisa a sus labios" (493), muy pronto se convierte en un viaje a un mundo donde reina la muerte. $\mathrm{Al}$ adentrarse por la estrecha vereda de un bosque vecino se topan con auras tiñosas devorando el cadáver de otro de los negros cimarrones, quien prefirió ahorcarse antes de entregarse o ser capturado y tener que regresar a la dotación. Las auras le habían extraído los ojos y la lengua y en ese instante comenzaban a devorar su corazón (493). El próximo camino que toman, con el afán de distraer a Isabel, quien había quedado muy afectada ante la escena, los conduce a un cercado con una cruz en el medio que resultó ser el cementerio donde enterraban a los esclavos del ingenio. Mudos, pasan de largo y toman otra guardarraya en dirección a la propiedad. Al travesar los cañaverales — extensos y cerrados en palabras de Villaverde - se tropiezan con tres negros que traen el cadáver de Pedro, el negro cimarrón mordido por los perros, quien también escogió el suicidio, tragándose su propia lengua, antes que volver a perder su libertad (495).

Este episodio es muy significativo porque a pesar de ser el blanco el que comete las atrocidades hacia los esclavos, es el cuerpo negro el que se presenta como monstruoso. La imagen del esclavo ahorcado siendo devorado por las auras, inmóvil, sin lengua, sin ojos y, muy pronto, sin corazón, es, sin duda, una imagen monstruosa. Una figura similar se muestra cuando se describe el cadáver de Pedro.

Horrorosa era su vista, habiendo adquirido ya la rigidez de la muerte. . . . A consecuencia de las mordidas de los perros, tenía hinchado los brazos, las piernas y levantado el pecho; los ojos casi fuera de sus cuencas e inyectados de sangre...

Contribuía a darle un aspecto feroz el tener la piel de la frente arrollada 
desde la línea de las cejas hasta el nacimiento de las pasas, y zajadas (sic) las mejillas verticalmente desde el párpado inferior hasta la orilla de la quijada, a usanza de la tribu en su país natal. Parte de esa costumbre era el aguzarse los dientes superiores, que dejaba ver a través de los labios entreabiertos, trabados con los de la mandíbula inferior. (485-486)

En el caso de esta descripción es evidente que la monstruosidad no sólo está dada por las marcas de la muerte, sino por las marcas culturales impregnadas en el cuerpo. Los cortes verticales en el rostro - como parte de la escarificación corporal- y los dientes afilados - una especie de mutilación dental— eran prácticas comunes dentro de los integrantes de algunas naciones africanas. El hecho de que sean percibidas por el hombre blanco como grotescas, cuando originalmente se realizaban tanto para embellecimiento como para identificación de los diferentes grupos étnicos, entre otros, pone al descubierto la construcción, en el imaginario colectivo blanco, de lo que Jeffrey Jerome Cohen, en "Monster Culture (Seven Theses)" ${ }^{145}$, denomina cultura monstruosa. Según este investigador, en tiempo de crisis, en momentos históricos culturales específicos, la figura del monstruo ha aparecido como una manifestación cultural que reencarna la diferencia, la otredad, el afuera, representando, de cierta manera, tanto el temor y la ansiedad como el deseo y la fantasía de la cultura que la construye. También explica Cohen que ha habido casos, diversos en la historia, donde la representación de una cultura anterior como monstruosa ha justificado su desplazamiento o exterminio, al ser interpretado el hecho como un acto heroico. Para Cohen, el cuerpo monstruoso es un cuerpo cultural (47).

En el caso específico de la Cuba azucarera decimonónica, se ha analizado en

\footnotetext{
145 "Monster Culture (Seven Theses)" es uno de los ensayos que conforman parte del estudio Monster Theory: Reading Culture (1996) editado por el propio Cohen.
} 
apartados anteriores que existía un latente miedo al negro, no sólo por la posibilidad de una sublevación de esclavos similar a la de Haití, sino también por temor a la africanización de la cultura. A pesar de ser esta una novela antiesclavista, la representación del cuerpo monstruoso en estos ejemplos responde a este temor. Más allá de las marcas culturales percibidas como grotescas, que terminan opacando la salvaje conducta del blanco ante la monstruosidad de la raza negra y justificando el brutal maltrato que éste acomete contra ella, de cierta manera también es importante destacar el hecho de que sea el negro cimarrón el que se presente como una figura monstruosa. La postura a favor de la abolición de la esclavitud responde entonces, en esta obra, a lo que Julio Ángel Carreras define como abolicionismo parlamentario, aquel propugnado y defendido por los blancos reformistas, quienes pretendían lograr su objetivos por las vías legales (19) —piénsese en los Proyectos de Varela y en el Análisis de Saco-, mientras que presenta, a través de la demonización del cimarrón, un rechazo al abolicionismo radical de los negros — la huida al monte de los esclavos constituyendo sus palenques de cimarrones y las rebeliones organizadas ${ }^{146}$ reclamando su libertad (20).

Aunque Villaverde se sensibiliza con el sufrimiento negro, delatando abiertamente las atrocidades cometidas por el hombre blanco, el rechazo y el temor que su clase sentía hacia la negritud se materializa en la monstruosa figura del cimarrón, por transgredir éste el orden establecido en la sociedad esclavista. El paisaje azucarero, consecuencia de la industria culpable del ennegrecimiento de la Isla, no sólo se convertía en un espacio racializado donde predominaba la presencia africana y se perpetuaban sus

\footnotetext{
${ }^{146}$ Durante el siglo XIX Cuba fue escenario de múltiples manifestaciones abolicionistas promulgadas por los negros y mulatos libres. Dentro de las más mencionadas en la historia se encuentran La Conspiración de Aponte (1812) y la de La Escalera (1844).
} 
diferentes culturas, sino que también devenía en un lugar de resistencia y desobediencia, por parte del negro, en contra de los estatutos sociales. Debido a esta condición, y en respuesta al marcado temor al negro existente en la sociedad, el paisaje azucarero se transformaba, para el hombre blanco, en un espacio racializado poblado de monstruos a las márgenes de la nación imaginada.

\subsection{LOS PAISAJES INTERMEDIOS DE LA SACAROCRACIA: ENTRE LAS PALMAS, LAS CAÑAS, LOS ESCLAVOS Y LAS MÁQUINAS}

En vano algunos escritores perspicaces, para echar un velo a la barbarie de las instituciones con las ficciones ingeniosas del lenguaje, han inventado los términos de campesinos negros de las Antillas, vasallaje negro, y protección patriarcal; porque es profanar las nobles artes del entendimiento y de la imaginación, el disculpar con comparaciones ilusorias o con sofismas capciosos los excesos que afligen a la humanidad... Alexander Von Humbolt

Aunque en los acápites anteriores me he concentrado mayormente en obras representativas del discurso anti-azúcar, aquel proyecto de la Cuba pequeña enfrentado al de la Cuba Grande, es importante destacar que con el transcurso del tiempo no terminó siendo éste el que prevaleció. El programa del Intendente de Hacienda Alejandro Ramírez $^{147}$ (1777-1821), que proponía un proyecto de diversificación económica donde los pequeños y medianos campesinos blancos abastecieran a la Isla de productos menores y que estipulaba la introducción de población blanca europea que ayudara a revertir la africanización del país, no logró detener la marcha implacable del programa de su substituto Claudio Martínez de Pinillos ${ }^{148}$ (1782-1853), Conde de Villanueva, quien

\footnotetext{
${ }^{147}$ Alejandro Ramírez fue Intendente de Hacienda por el período de 5 años, desde 1816 hasta 1821.

${ }^{148}$ Claudio Martínez de Pinillos substituyó a Alejandro Ramírez en calidad de intendente en 1821 y fue nombrado oficialmente a este cargo en 1825 hasta 1851.
} 
abogaba por la modernización de la agroindustria azucarera, pero manteniendo el sistema de plantación esclavista ${ }^{149}$.

De la misma manera que Heredia, Avellaneda y Villaverde, entre otros, borraron a la gramínea de muchos de sus paisajes, en el caso del primero, o la representaron con cierta aversión — dejando a relucir un latente rechazo a la industrialización, a la esclavitud y a la consecuente africanización de la Isla - existe todo un corpus literario que sí integró a la caña dentro de sus paisajes naturales como un símbolo identitario de la nación, sin que esta inclusión constituyera ningún conflicto. El propio Heredia en su poema $\mathrm{Al} \mathrm{sol}(1823)^{150}$, donde le agradece a éste la virginal belleza de la patria, menciona como los rayos solares maduran "la más dulce de las plantas,/ y del café las sales deliciosas" ${ }^{\prime 151}$, una muy posible referencia, en el primer verso, a la caña de azúcar. Tampoco tiene reparos en incluirla en los primeros versos de su famoso En el Teocalli de Cholula (1820), donde las llama "cañas deliciosas" "152, aunque el paisaje que describe en este poema, vale la pena señalar, es de México y no de Cuba. Unas décadas más tarde,

\footnotetext{
${ }^{149}$ Para más información sobre ambos proyectos, además de la obra de Friedländer antes mencionada, se pueden consultar los artículos "El Conde de Villanueva y la alternativa de la Cuba Grande", de Manuel Barcia, y "Un edén ilustrado bajo el cielo de los trópicos", de Miguel Ángel Puig-Samper, ambos recopilados en Francisco Arango y la invención de la Cuba azucarera (2009). También se puede consultar la obra Economía y colonia (2004) de Antonio Santamaría García y Alejandro García Álvarez.

${ }^{150}$ El poema fue escrito entre 1821 y 1823 , antes de partir al exilio.

${ }^{151}$ En el fragmento completo del poema se lee: "Mi Patria...joh Sol. . . ! Mi suspirada Cuba,/¿A quién debe su gloria,/a quién su eterna virginal belleza?/Sólo a tu amor. Del Capricornio al Cáncer/en giro eterno recorriendo el centro,jjamás de ella te apartas, y a tus ojos/ de cocoteros cúbrese y de palmas/y naranjos preciosos, cuya pompa/nunca destroza el inclemente yelo./Tus rayos en sus vegas/desenvuelven los lirios y las rosas,/maduran la más dulce de las plantas,/y del café las sales deliciosas.” (39-51).

${ }^{152}$ En la primera estrofa del poema se lee: ¡Cuánto es bella la tierra que habitaban,/Los aztecas valientes! En su seno/En una estrecha zona concentrados,/Con asombro se ven todos los climas/Que hay desde el Polo al Ecuador. Sus llanos/Cubren a par de las doradas mieses/Las cañas deliciosas. El naranjo/Y la piña y el plátano sonante,/Hijos del suelo equinoccial se mezclan/A la frondosa vid, al pino agreste,/Y de Minerva el árbol majestoso." (1-11).
} 
para continuar con una tradición literaria inclusiva, ya José de Jesús del Osio (18121862) la incorporaría dentro de la simbología poética con la que se define y distingue la nación cubana, en su poema Amor patrio (1853) —en una clara postura independentista de ruptura con el poder colonial-:

Yo no dejo a San Juan por el Henares ni un solar de mi Cuba por España, ni por su pera nuestra dulce caña ni por montes de olivos mis palmares. ${ }^{153}$

La peculiaridad de estos versos es que tanto la gramínea como la palma son elementos con los que se identifica la patria - lo propiamente cubano- sin que aparentemente exista ninguna tensión. En ellos se presenta una especie de cuadro armónico en los que la industria — la caña de azúcar - y la naturaleza edénica de la Isla — la palma — se concilian, un fenómeno que bien puede responder al concepto de middle landscape (paisaje intermedio) propuesto por Leo Marx.

En The Machine in the Garden ${ }^{154}$, Marx describe y examina como al ideal pastoril con el que se interpretó Norteamérica, tras haber sido descubierta por los europeos, poco a poco se le fue introduciendo la presencia de la máquina, sin que necesariamente afectara esta transformación la esencia edénica que se le había atribuido a la tierra. Aunque era, evidentemente, una contradicción, el jardín — los paisajes pastoriles — y la máquina — como símbolo de la industrialización- lograron fundirse manteniendo lo que Marx define como American pastoralism (pastoralismo americano).

En principio, tras los avances científicos y tecnológicos que se sucedieron a finales del siglo XVIII, Europa fue sacudida por una ola de entusiasmo que reclamaba los

\footnotetext{
${ }^{153}$ Nótese que todos los énfasis en este fragmento del poema han sido añadidos.

${ }^{154}$ The machine in the garden: Technology and the Pastoral Ideal in America (1964).
} 
paisajes rurales y su modo vida (74). Norteamérica, que ya había sido descrita por los primeros viajeros como un jardín natural de asombrosa fertilidad ${ }^{155}$, se ofrecía como el lugar idóneo donde hacer realidad este ideal pastoril. La imagen de la tierra como un nuevo paraíso de la abundancia, aunque ya existente en el imaginario colectivo - y en la literatura - llega, en esta época, a ser completamente articulada y aplicada a la realidad. Norteamérica era la tierra donde finalmente se llevaría a cabo $-\mathrm{y}$ con éxito- the pursuit of happiness (73-75).

Cabe destacar que la interpretación de Norteamérica como un jardín, más allá de la imagen mitológica de la tierra edénica, también comenzó a vislumbrarse, según Marx, como la tierra cultivada de la abundancia. Como resultado se creaba un paisaje de la reconciliación, un lugar apacible donde la agricultura y la naturaleza silvestre se conjugaban. Este jardín semi-primitivo — variación moderna del ideal pastoril—, que le ofrecía al hombre un estado intermedio entre el primitivismo y la civilización, pronto se convirtió en una imagen recurrente en la literatura norteamericana (84-86). Más adelante, sería a este mismo jardín al que se le introduce la máquina.

Sin dejar de enfatizar en la esencia agraria norteamericana, la industrialización de la naciente nación, una vez liberadas las colonias de la metrópoli, comenzó a hacerse una necesidad. La máquina, lejos de las oscuras, superpobladas y mugrientas ciudades europeas se fundiría armoniosamente en la vasta campiña norteamericana, ayudando a transformar la tierra salvaje en una sociedad que reflejara el paisaje intermedio. La tierra, percibida en esta parte del mundo como purificadora — capaz de rehabilitar a la

\footnotetext{
${ }^{155}$ Marx hace referencia al informe escrito por el capitán Arthur Barlowe sobre su viaje a Virginia en 1584 y las descripciones escritas por el capitán John Smith, también sobre Virginia, en 1612 y en 1624 (75).
} 
envilecida máquina - se convertía en un locus que encerraba ambos valores: el económico y el moral (150). De esta manera, la noción de que la industria también podía formar parte del ideal pastoril se sedimentaba, mientras que la máquina se comenzaba a apreciar como un símbolo cultural de la nación (163).

Más allá de las referencias literarias a las que se aluden en este estudio que abrazan esta versión industrializada del ideal pastoril —Thoreau, Emerson y Whitman, entre otros escritores ${ }^{156}$ - , son las lecturas de los discursos de Tench Coxe ${ }^{157}$ (17551824) yuxtapuestos a la pintura de George Inness (1825-1894), los aspectos que me interesan comentar brevemente, por su semejanza y aplicación al que terminó siendo uno de los textos más valiosos y representativos de la sacarocracia cubana: Los ingenios ${ }^{158}$ (1855-1857), de Justo G. Cantero ${ }^{159}$.

Tench Coxe era un joven comerciante de Filadelfia a quien se le reconoce haber sido uno de los primeros y más astutos voceros de los intereses de la creciente manufactura norteamericana; mientras que George Innes era un pintor paisajista a quien

${ }^{156}$ Walden (1854) de Henry David Thoreau, The New Pastoral (1855) de Thomas Buchanan Read, Passage to India (1868) de Walt Whitman y Nature (1836) de Ralph Waldo Emerson, son algunas de las obras literarias a las que Marx hace referencia.

${ }^{157}$ Marx examina fundamentalmente dos discursos que diera Coxe en 1787: An Enquiry into the principles, on which a commercial system for the United States of America should be founded, presentado a la Sociedad para Investigaciones Políticas (Society for Political Enquiries) en la casa de Benjamin Franklin y el discurso inaugural de la reunión organizada por la Sociedad de Pennsylvania para el Fomento de la manufactura y las artes útiles (Encouragement of Manufactures and the Useful Arts).

${ }^{158}$ Los ingenios: colección de vistas de los principales ingenios de azúcar de la Isla de Cuba.

${ }^{159}$ Justo G. Cantero (1815-1870) nació en Trinidad en la actual provincia de Santi Spíritus. Aunque cursó estudios de medicina en Estados Unidos y siempre ejerció como médico a su retorno a la Isla, a través de su matrimonio con Monserrate Fernández de Lara y Borrell, viuda del hacendado Pedro Iznaga y Borrell, pasó a ser dueño de cinco ingenios a los que luego adicionó otros tres. Además de atender su consulta y las plantaciones también estuvo involucrado en otros proyectos relacionados al desarrollo de la ciudad. Debido a los cambios que ocurren en la industria azucarera y a la mala administración de su fortuna fallece totalmente arruinado en 1870. Para más información sobre Cantero y la sacarocracia cubana en general, puede consultar La sacarocracia: historia de la aristocracia azucarera cubana (2006) de Rubén C. Arango. 
se le comisionó una pintura donde representara la primera casa de máquinas del ferrocarril de Lackawanna ${ }^{160}$. Lo valioso en Coxe, según Marx, es que elabora un discurso a favor de la industrialización, pero insistiendo en que la máquina es un mero instrumento, mientras que la agricultura es la verdadera fuente de poder de la joven nación (155). La implantación de la manufactura, de la manera que la presenta, permitiría aprovechar al máximo las riquezas naturales del país para beneficio de los agricultores y plantadores, quienes entendía eran el baluarte de la nación (156-157). Los discursos de Coxe eran representativos del ideal pastoril del paisaje intermedio, justamente porque en ellos se mezclaban armoniosamente las fábricas y las máquinas dentro de la escena rural; el paisaje representaba un imagen equilibrada donde se combinaba lo mejor de las artes —o del artificio — con lo mejor de la naturaleza (160).

En el caso de la obra de Inness, aunque en principio no estaba muy convencido de cómo insertar la industria ferroviaria -locomotoras, casa de máquinas, taller de reparaciones, entre otros - dentro de sus paisajes virgilianos, su pintura The Lackawanna Valley (1855) terminó siendo, según Marx, la obra pictórica por excelencia que encarna la versión industrializada del paisaje intermedio (219-220). En el lienzo Inness plasmó una vista panorámica del valle de Lackawanna, donde además de la naturaleza de la región también destaca una locomotora en curso y algunos edificios industriales. Marx entiende que las montañas al fondo y los árboles ubicados en el plano intermedio del cuadro de cierta forma rodean - y yo diría que suavizan - las edificaciones y los artefactos, fundiéndose y complementándose, de esta manera, ambos elementos. También

\footnotetext{
${ }^{160}$ En 1854 el presidente de Delaware, Lackawanna \& Western Railroad le encargó a Inness una pintura donde incluyera las locomotoras y la casa de máquinas, aún por terminar, del ferrocarril en el Valle de Lackawanna.
} 
comenta que no hay líneas agudas que distingan o dividan lo artificial de lo natural, ni que el blanco humo que despiden las máquinas resulte desagradable. Además de estas observaciones, señala que es significativo que los animales continúen pastando o descansando en la hierba tranquilamente, a pesar de que la locomotora se aproxima. Pero es, según él, la imagen que aparece en primer plano, esa figura solitaria — supuestamente de un hombre - reclinada en el pasto cerca de un inmenso árbol, el elemento que establece, de manera definitiva, el estado relajado y de quietud del conjunto. Aunque no lleva cayado, dice Marx, el hombre contempla el panorama en la serena postura que adoptaría un buen pastor atravesando con la mirada la Arcadia (220-221). Para Marx, ninguna otra obra ha reflejado la introducción de la máquina en el jardín edénico norteamericano como lo hizo Innes en este cuadro.

A pesar de las notables diferencias entre la creación de la nación estadounidense y la cubana - las maneras disímiles en que fueron descubiertas por los europeos, colonizadas y, posteriormente, imaginadas - cuando se analizan y comparan las ideas de Coxe con las del hacendado trinitario Justo G. Cantero, como exponente de un discurso a favor de la renovación industrial azucarera, no pueden dejar de apreciarse ciertas similitudes ${ }^{161}$. Coxe entendió que la industrialización del país era la opción que tenían las recién liberadas colonias para salvar económicamente la nación y mostrar su poderío. Consciente de la importancia que tenían la agricultura y la visión edénica de la tierra dentro del imaginario colectivo norteamericano enfatizó en el papel secundario de la máquina, otorgándole mayor valor a la fertilidad y a las riquezas del suelo. La

\footnotetext{
${ }^{161}$ No en balde fue Cantero uno de los hacendados que apoyaron la conspiración anexionista que se produjo en Trinidad, encabezada por Isidoro Almenteros, conocida como la Conspiración de 1851.
} 
manufactura, lejos de tronchar a los agricultores, le permitiría alcanzar la gloria a la República agraria. The Lackawanna Valley sería, años más tarde, un reflejo del triunfo de este discurso pro-industrial, conciliador, que lograba armonizar dentro del ideal pastoril a la máquina.

Aunque fuera Arango, en Cuba, uno de los precursores del discurso de la plantación y se le atribuye a él la invención de la Cuba azucarera, se puede apreciar en Cantero una figura clave dentro de este discurso durante la edad de oro de la agroindustria cañera. Arango, en su momento, entiende que el fomento del cultivo extensivo de la caña era la opción que tenía la Isla para despojarse del atraso económico y alcanzar el desarrollo de las grandes colonias vecinas; de la misma manera que Cantero, unos años más tarde, enfatiza en la importancia de la mecanización de la industria para poder competir en el mercado internacional.

Si se comparan las fechas y los contextos históricos, los discursos de Coxe y los de Arango comparten en común la intención de proyectar económicamente la nación hacia el futuro. Son discursos visionarios que a pesar de su naturaleza económica también pertenecen al corpus fundador de la nación. El uno apostaba por la maquinaria, renovadora de la agricultura en general; mientras que el otro depositaba su confianza en el cultivo de un producto que dependía de la industria. Ambos, de cara al siglo XIX, imaginaban naciones dominadas por un paisaje intermedio, donde la máquina sería un elemento armonizado dentro del ambiente rural.

Seguidor del discurso de la plantación propuesto por Arango, cuando la agroindustria azucarera cubana había dejado de ser un sueño para convertirse en una realidad, Cantero produce la obra Los ingenios con la colaboración del pintor Eduardo 
Laplante $^{162}$ y el impresor Louis Marquier ${ }^{163}$. En 1855 se publican las primeras ilustraciones, hechas por Laplante, acompañadas de los textos descriptivos, a cargo de Cantero. A partir de ese momento se seguirán otras entregas con el resto de las litografías y sus respectivas descripciones por el período de dos años. En cada una de ellas se alternarán vistas exteriores de los ingenios con imágenes hechas en el interior de las fábricas. La obra, en su conjunto, se pudiera interpretar como una oda a la industria azucarera y en especial a la máquina.

Las motivaciones de este empeño, según Cantero, eran “dar a conocer los adelantos y esfuerzos que impend[ía]n los agricultores para seguir la marcha universal del progreso y generalizar esos conocimientos [dentro del país]" (89). Entendía que era su deber - y el de los otros hacendados - promover las mejoras y reformas necesarias de la agroindustria azucarera para el bien de la comunidad (89). Otras intenciones, aunque no mencionadas, serían proporcionarle deleite a los sacarócratas, al inmortalizar en sus páginas las magníficas obras de arquitectura que constituían los ingenios de azúcar y la avanzada tecnología que habían implementado; además de promocionar la industria dentro de los mercados de Estados Unidos y Europa, de cuyas inversiones se dependía (García y Santamaría 17-18).

\footnotetext{
${ }^{162}$ Eduardo Laplante (1818-1860) fue un pintor, litógrafo y agente comercial francés. Llegó a Cuba en 1848 en calidad de representante de una fábrica de equipos para la industria azucarera y un año más tarde ya se incorpora al quehacer artístico de la Isla como litógrafo. Además de Los ingenios, también en el taller litográfico de Marquier, litografía una serie de vistas panorámicas de distintas ciudades de Cuba. Para más información sobre su obra, se puede consultar La memoria de las piedras (2002), estudio de Zoila Lapique Becali sobre la historia de la litografía en Cuba.

${ }^{163}$ Louis Marquier (1814-?) fue un litógrafo francés que llegó a la Isla en 1846. Luego de trabajar en otros talleres litográficos abrió su propio taller en 1849. Además de Los ingenios, en él se imprimieron varias de las obras más importantes del siglo XIX cubano, como fueran el Álbum californiano, con ilustraciones de Francisco Ferrán y José Baturone, y la serie Viaje pintoresco por la Isla de Cuba, con grabados de Federico Miahle. Para más información sobre el quehacer litográfico de Marquier se puede consultar la obra de Zoila Lapique mencionada en la nota anterior.
} 
El crecimiento de la producción del azúcar de remolacha, que acaparó parte del mercado europeo; los altos tributos de venta impuestos por la metrópoli y el encarecimiento de la trata, en una época donde ya muchos países habían abolido la esclavitud y criticaban fuertemente el sistema esclavista, eran problemas a los cuales parte de la sacarocracia había respondido con la modernización de los ingenios y la infraestructura azucarera en general. Además de la construcción de los ferrocarriles, plantadores como Cantero, habían implementado en sus fábricas los últimos adelantos técnicos con el fin de producir más azúcar y de una mejor calidad (García y Santamaría, 18). En esta obra Cantero planteaba la necesidad que tenían las hacendados cubanos de continuar adoptando los avances tecnológicos en la producción del azúcar, para poder competir en el mercado internacional; además de que reforzaba la idea de que era la modernización de la industria la que había permitido el desarrollo azucarero de la Isla (100). Como resultado, Los ingenios presenta un paisaje intermedio donde se armonizaba la naturaleza edénica de la Isla y la máquina.

De la misma manera que Coxe insiste en la importancia de la industria como herramienta que podría maximizar el valor de la tierra, sin dejar de reconocer que era ésta la verdadera fuente de poder de la nación, Cantero también acentúa en el crucial papel de la mecanización para obtener un mayor rendimiento y una mejor calidad, resaltando que ya se tenía la fortuna de contar con un suelo fértil, superior al de otros países o colonias productoras de azúcar (97). Su discurso, como el de Coxe, luego de reconocer el milagro de la tierra, hablaba sobre el milagro de la máquina, elemento decisivo para que Cuba continuara siendo la azucarera del mundo. "La ciencia y el arte [decía] han hecho producir a la desabrida remolacha el $8.5 \%$ de su peso en la azúcar cuando la dulcísima 
caña no nos ha rendido a nosotros todavía el cinco" (100). Si gracias a los avances científicos y tecnológicos la desabrida remolacha había logrado ese alto rendimiento ¿qué positivos resultados no podrían esperarse de la caña de azúcar? Era evidente que los adelantos técnicos se percibían, según este discurso, como herramientas imprescindibles para lograr alcanzar una mayor productividad en la industria.

Además de la importancia de la máquina, Cantero también insiste en el excepcional mérito de la caña, cuyo principal derivado para esas fechas había dejado de ser un lujo y se había convertido en un producto de consumo de primera necesidad ${ }^{164}$.

En todas partes encuentra un lugar preferente, desde los soberbios palacios hasta la más infeliz cabaña, en los festines durante la primavera gloriosa de la vida, cuando la fruición más perfecta y sus más elevados deseos hacen de la tierra un edén; en medio de esas escenas donde Dios puede mirar con complacencia los corazones enlazados por aquella misteriosa afinidad y simpatía jurándose eterna unión en felicidad o infortunio, y en el lecho de la miseria y dolor en las manos del ministro de la esperanza y alivio que nos ofrece los jarabes para ocultar el acíbar de las medicinas y contrariar las influencias de las enfermedades . . .; en todas partes, por fin, se reconoce como uno de los productos más preciosos con que la Providencia ha dotado a sus criaturas. (92)

Si milagrosa eran la tierra y la máquina, igual de milagrosa era la caña.

Ahora bien, de la misma manera que imaginar a Cuba sin paisajes azucareros era un acto de violencia que pretendía omitir parte de la realidad de la Isla, armonizar esta industria dentro de una tierra que también se había percibido desde el descubrimiento como edénica, constituía una nueva violación. Las vistas exteriores de los ingenios y las imágenes interiores de las fábricas que se reproducen en las litografías distan mucho de aquel primer paisaje industrial que se describiera en Cecilia, una vez entraran los viajeros

\footnotetext{
${ }^{164}$ Para comprender cómo el azúcar dejó de ser un lujo excepcional y se convirtió en un producto de primera necesidad puede consultar las obras Sweetnes and Power: The Place of Sugar in Modern History (1985) de Sidney W. Mintz y Sugar and Civilization: American Empire and the Cultural Politics of Sweetness de April Merleaux.
} 
en los dominios azucareros. Villaverde detallaba el movimiento y el vocerío incesante que se presenciaba durante la molienda de la caña y la cocción del azúcar en un ingenio. Más allá del ruido de los hombres, las bestias y las máquinas — que se denominaba en el texto de estrépito infernal - el dantesco cuadro era completado con el calor de las hirvientes calderas desprendiendo un vapor cegador (427). La industria azucarera, según este pasaje, se relacionaba a un locus grotesco y ensordecedor.

A pesar de que la mayoría de las litografías de Los ingenios muestran a los esclavos negros y a los culíes ${ }^{165}$ enfrascados en las faenas azucareras y que varias de ellas detallan la maquinaria y los avances tecnológicos adoptados por los sacarócratas en sus fábricas, ninguna trasmite el ruido, la inquietud o el sofocante calor que describiera Villaverde en su obra — como parte del proceso azucarero - que convertía a la industria en un cuerpo monstruoso. Tampoco predomina en estos dibujos ese aspecto lúgubre y áspero que presenciara el viajero villaverdiano cuando posaba su mirada en la región donde imperaban las plantaciones cañeras y los ingenios de azúcar; estampa que, según el autor, trocaba la admiración en disgusto y la alegría en lástima (423). Si la presencia de la agroindustria azucarera interrumpía la tranquilidad del idílico paisaje nacional en la novela de Villaverde y otras obras antes analizadas, en las litografías de Laplante y los textos descriptivos de Cantero, los ingenios y los cañaverales se integran armoniosamente a la naturaleza virgiliana de la Isla creando un paisaje conciliatorio ${ }^{166}$, similar al concepto de paisaje intermedio propuesto por Marx. De las diversas litografías que cumplen esta

\footnotetext{
${ }^{165}$ Nótese que ya para estas fechas se habían contratado trabajadores chinos y de otras regiones de Asia en muchos de los ingenios altamente mecanizados.

${ }^{166}$ Carlos Venegas Fornias entiende que la obra propone un paisaje moderno, agrario, donde la racionalidad y el orden propios de la naturaleza industrial o tecnológica predominan (El libro de Los ingenios [1996]).
} 
función "El Valle de la Magdalena" $(1856){ }^{167}$ se pudiera tomar como la obra por excelencia que representa la aceptación de la máquina como un elemento más dentro del paisaje pastoril cubano, de la misma manera que lo fuera la pintura de Innes para Norteamérica.

La escena fue tomada desde la loma del Paraíso y en ella se detalla una vista panorámica del valle Magdalena en la actual provincia de Matanzas. Unidos a la naturaleza de la región — las montañas, el mar al fondo y las innumerables palmas - se destacan numerosos ingenios azucareros con sus torres humeantes y una masa verde perteneciente a las plantaciones de caña. Delimitando los sembrados y las propiedades, relucen diferentes veredas y guardarrayas. En el primer plano, atravesando un camino, se distingue la figura de un jinete, probablemente un campesino, y un poco más al fondo otro jinete seguido de una hilera de animales de carga. También en el primer plano, junto a otros árboles y arbustos, resaltan unas inmensas palmas. Al igual que en la obra de Innes, el hecho de que las montañas y los árboles rodeen las edificaciones hacen que ambos elementos se complementen $\mathrm{y}$ formen parte del paisaje de una manera armonizada. Si hubiera que renombrar esta obra, bien pudiera llamarse "El valle de los ingenios y las palmas". Acompañando el dibujo en la descripción de Cantero se puede leer:

[A]quella magnífica llanura limitada a lo lejos por pintorescas lomas presenta un aspecto tan encantador vista desde las alturas inmediatas, que difícilmente podría la imaginación concebir uno más bello, sobre todo cuando sale y se pone el sol, o por la mañana al ostentarse cubierta de una ligera niebla que le da el aspecto de un inmenso lago circular sobre el cual asoman las copas de las palmas mecidas blandamente por el terral, o los

\footnotetext{
${ }^{167}$ Esta litografía es la número 15 de la obra y apareció en la cuarta entrega en febrero de 1856 (García y Santamaría 71).
} 
techos de algunos ingenios que de distancia en distancia muestran sus elevadas torres coronadas de vapor y humo, mientras que a sus pies despliega su brillante verdor la ondeante caña, base principal de la riqueza de nuestra Isla. (207)

Lo que armonizaba Laplante con su pincel, afirmaba Cantero con sus palabras: los ingenios y los cañaverales eran en el siglo XIX cubano parte integral del edénico paisaje.

Aunque en la obra hay diecisiete esplendidas litografías que detallan las vistas exteriores de los ingenios cumpliendo esa función conciliadora entre la naturaleza y la máquina, este dibujo del valle resume la importancia de la agroindustria azucarera en la Cuba decimonónica y su constante presencia en los paisajes rurales. Benítez Rojo, en $L a$ isla que se repite, hablaba de Los ingenios como un "conjunto de láminas y textos [que] constitu[ían] una suerte de panoplia poética o mito que [se] $\mathrm{p}$ [odía] tomar como un monumento al poder" (141). Decía que en su mente veía una especie de ingenio descomunal: un parque de máquinas y aparatos, edificios, caminos, vías férreas y chimeneas que dinamizaban el verde y apacible paisaje de la campiña (141-142). "El Valle de la Magdalena”, por sí sólo, responde a esta descripción.

Además de armonizar la naturaleza y la máquina, la manera en que el trabajo esclavo se representa en esta obra permite que la industria azucarera no constituya un elemento discordante dentro del ideal pastoril. Moreno Fraginals explicaba como las largas jornadas de trabajo durante la zafra — dieciocho horas y en ocasiones másconducían a la fatiga residual, un cansancio que se acumulaba con el tiempo y que conllevaba a la reducción precoz de la capacidad laboral y al envejecimiento prematuro (288). Debido a este constante agotamiento, era común que durante las faenas el sueño venciera a los esclavos y como consecuencia sufrieran algún accidente que en ocasiones 
podía ser mortal. Brazos triturados por los trapiches, quemaduras con el hirviente guarapo, entre otros, eran estampas usuales dentro de la vida del ingenio (288).

En la literatura de la época Anselmo Suárez Romero (1818-1878), en su ensayo "Los ingenios" (1859), resume acertadamente esta extenuante labor. Durante la visita que realizara a una plantación en las afueras de La Habana, reflexiona acerca de las marcadas diferencias existentes entre las faenas azucareras y las que se realizaban en los cafetales. Según él, recolectar el café y sembrar o podar los cafetos eran tareas muy sencillas, que lejos de molestar distraían a los negros (196). En los ingenios, sin embargo, además de ser verdaderamente agobiantes las labores azucareras, los esclavos estaban forzados a realizarlas bajo condiciones extremas.

Los negros [cuenta Suárez Romero] se levantan mucho antes de rayar la aurora, y luego no tienen ni lindas guardarrayas, ni frescas arboledas, ni olorosos jardines donde trabajar a la sombra. Cortar caña, si es tiempo de molienda, al resistero del sol durante el día, meterla en el trapiche, andar con los tachos y las pailas, atizar las fornallas, juntar caña, acarrearla hasta el burro; por la noche hacer estos trabajos en los cuartos de prima y de madrugada al frío y al sereno muriéndose de sueño, porque para diez y nueve (sic) horas de fatiga sólo hay cinco de descanso; y, acabada la zafra, sembrar caña y chapear los cañaverales, que es de las faenas más recias de un ingenio por la postura del cuerpo inclinado hacia la tierra ... y todo aguantando las copiosísimas lluvias de la estación de las aguas entre el fango y la humedad. (196-197)

Además de esta agobiante labor relacionada a la producción azucarera, también hay que considerar que los castigos físicos eran muy frecuentes en las plantaciones. Al negro no sólo se le maltrataba cuando mostraba algún comportamiento rebelde, la lentitud y la negligencia laboral, productos del cansancio, también eran castigadas con el látigo del mayoral. En la novela Francisco $(1838)^{168}$, otra obra de Suárez Romero, a

\footnotetext{
${ }^{168}$ Aunque no tan conocida como Cecilia y Sab, Francisco es otra de las novelas antiesclavistas de la
} 
Francisco se le golpea y se le tortura, en varias ocasiones, hasta llegar al desmayo y luego, aún extremadamente débil, se le saca de la enfermería y se le obliga a incorporarse al corte de caña. En Cecilia hay un pasaje donde también se describe el extremo castigo físico que recibe una de las esclavas cimarronas que había decidido regresar a la dotación y en un cuento de Pedro José Morillas (1803-1881), que lleva como título El ranchador $(1838-39)^{169}$, los rancheadores observan impasibles como los perros despedazan a un cimarrón herido.

Ninguna de las ilustraciones de Los ingenios muestra cuan extenuantes eran las labores azucareras. Las figuras de los esclavos y los culíes no traslucen el inevitable agotamiento corporal después de estar sumidos, por horas, en las faenas agrarias o fabriles. Tampoco se muestra el desgaste de las ropas o la suciedad. El cuerpo negro, en estas litografías, no lleva las ineludibles marcas de los años que se ha vivido en la esclavitud: largas jornadas de trabajo, pobre alimentación y escasas horas de sueño, que conllevaran a aquella fatiga residual y a aquel envejecimiento prematuro del que hablara Moreno Fraginals. De la misma manera que no aparece el látigo del mayoral, tampoco aparecen las cicatrices, los grilletes o las mutilaciones corporales, ya sea por castigo o accidente laboral. El cuerpo esclavo, en general, se presenta fresco, saludable, impoluto, en un ambiente de trabajo limpio, apacible y cordial. Como muestra representativa de ello, se puede observar la litografía dedicada a la casa de calderas del Ingenio Asunción. En ella aparece en primer plano un esclavo recostado contra una columna con las piernas

época. Fue incluida por Domingo del Monte (1804-1853) en el portafolio de textos antiesclavistas que le entregara al Superintendente de Africanos Libertos de la Isla de Cuba por Delegación de Gran Bretaña Richard Roberto Madden (1798-1888).

${ }^{169}$ Cuento antiesclavista que también fuera incluido en el portafolio que Del Monte le entregara a Madden (ver nota anterior). 
y brazos cruzados y en una mano apoyando la barbilla, en una clara postura de ocio. También se puede examinar la vista exterior del ingenio El Narciso, donde se recrea, en el primer plano de la derecha, un grupo de esclavos bañándose apaciblemente en una represa $^{170}$. La visión idílica y esterilizada que muestran estas láminas evidencian que dentro de los propósitos que persiguió Laplante al dibujarlas no se encontraba la crítica a la esclavitud.

En cuanto a los textos descriptivos de Cantero, hay una marcada intención por demostrar que el trato que recibían los esclavos por parte de sus amos no era otra cosa que benévolo. Al igual que en las litografías de Laplante, la brutalidad blanca y el sufrimiento negro, propios de la esclavitud, son completamente omitidas o falseadas, algo que se puede apreciar en la Introducción a la obra escrita por el hacendado trinitario:

Puede decirse en elogio de los propietarios que los sentimientos de humanidad son los que reinan, contribuyendo la ilustración de nuestros días el modo mejor con que son tratados nuestros siervos $^{171}$; así es que la agonías físicas que inflige el castigo se observan sólo en casos muy extremos. Este trato benigno es causa de que se note un aumento considerable en el número de esclavos nacidos, contribuyendo a esto el esmero con que son cuidados los enfermos. (103)

Hay que destacar que algunos de los puntos a los que aludía Cantero no eran del todo desacertados, si se tiene en cuenta que el buen trato que pudieran recibir los enfermos era producto de la necesidad que se tenía de garantizar la mano de obra. La prohibición de la trata había encarecido el precio del esclavo y esto condujo a una tendencia, por parte de los amos, a mejorar las condiciones de vida de sus negros,

\footnotetext{
${ }^{170}$ Referencia a las litografías número 7 ("Casa de calderas del ingenio Asunción”) y 16 ("Ingenio El Narciso"). Estas dos estampas también fueron comentadas por Isabel Serrano León en su estudio "El libro Los ingenios" (1979).

${ }^{171}$ Énfasis añadido.
} 
suavizando, de cierta manera, el inhumano tratamiento que se les propiciaba (Moreno Fraginals 228, García y Santamaría 28, Serrano 100-101). Por otra parte, también en respuesta a la posible carencia de brazos, se van a encontrar los criaderos destinados a la reproducción de esclavos. Antes de que se produjera la inestabilidad en el mercado negrero y con ella el encarecimiento del negro, la cría de esclavos era una práctica que no resultaba rentable. A finales del siglo XVIII, sin embargo, previendo la crisis futura, Arango y Parreño propone el fomento de la introducción de más mujeres en las dotaciones para de esta manera, entre otras cosas, promover la reproducción (cit. en Moreno Fraginals 296). Unas décadas más tarde las estadísticas muestran que esta política había sido adoptada, paulatinamente, por los hacendados esclavistas $^{172}$. El aumento considerable de criollitos, vocablo eufemístico con el que Cantero se refería a los esclavos nacidos en la Isla, lejos de ser el resultado de una postura humanista, hundía sus raíces en una necesidad económica: la emergencia de la sacarocracia por asegurar la mano de obra.

A diferencia del discurso anti-azúcar, Los ingenios, como obra representativa del discurso de la plantación, no se inventaba monstruos ante el pavor a la africanización o a una sublevación de esclavos. Su prioridad no consistía en alimentar el existente temor al negro, sino en balancear el retardatario sistema esclavista con la implementación de los últimos adelantos científicos y tecnológicos. Para justificar la perpetuación de la mano de obra esclava, tanto en el texto como en las litografías, se esterilizaba la realidad, ocultándose la monstruosidad de la institución esclavista. El monstruo, evidentemente,

\footnotetext{
${ }^{172}$ Para más información sobre la introducción de negras y las políticas de reproducción adoptadas por los sacarócratas puede consultar el acápite "Sexo y producción" (293-308), de la obra El ingenio de Moreno Fraginals.
} 
era la industria azucarera con sus negros y sus máquinas y aquella plantación extensiva de cañaverales que se iban tragando la Isla. Cantero y Laplante, sin embargo, glorifican — e inmortalizan - a la gran sacarocracia cubana: la verdadera causante de la riqueza y el progreso de la nación. Como resultado, Los ingenios propone un paisaje intermedio, conciliatorio, que incorpora a la máquina, a la caña y al negro — siempre supeditado al sistema esclavista de la plantación azucarera-, como símbolos identitarios de la nación. A pesar de la presencia de estos elementos, la obra le devuelve a los campos de Cuba los paisajes equilibrados y maravillosos que el discurso anti-azúcar pretendía borrar. Un siglo después, curiosamente, el gobierno revolucionario adoptará este discurso pro-industrial de la sacarocracia, a pesar del carácter proletario ostentado por la Revolución. 


\section{CAPÍTULO 3}

\section{AZÚCAR AGRIDULCE: DISCURSOS AZUCAREROS HEREDADOS Y EL}

\section{TRIUNFO DE LA REVOLUCIÓN}

\subsection{DE LOS INGENIOS A LA ANTIEPOPEYA AZUCARERA Y NACIONALISTA:}

\section{LA CAÑA DE AZÚCAR ENTRE LA MELANCOLÍA Y LA ÉPICA NACIONAL}

Durante las primeras décadas del siglo XX, luego de haber ido desplazando desde mediados del XIX al café, al tabaco y al cobre, el azúcar se había entronado como el principal producto de exportación. En cuanto a su consumidor, ya desde finales de la década de los años setenta de la Cuba decimonónica, Estados Unidos se había convertido en su mercado primordial. Los días en que las exportaciones también se repartían entre España, Inglaterra, Alemania, Francia y otros países europeos, además de algunas regiones en Latinoamérica, iban quedando atrás.

Tener al gigante del Norte como casi único comprador, no obstante, presupuso un cambio en la producción azucarera cubana. Las refinerías norteamericanas — negocio en expansión durante aquella época - necesitaban de azúcares de baja polarización que les sirvieran como materia prima. La producción de azúcar blanca, aunque seguía siendo codiciada por los comerciantes norteamericanos no refinadores, irá disminuyendo y para finales del siglo ya Cuba se habrá especializado en la elaboración de crudos que alimenten las grandes industrias estadounidenses (Moreno Fraginals 425-439).

La gran sacarocracia criolla que en la década de los años cincuenta se vanagloriaba de su poder, aquel grupo — representado en la figura de Cantero y en su obra Los ingenios — que había hecho grandes esfuerzos por industrializar la producción azucarera, implementando las más modernas tecnologías en sus fábricas, languidecía, al 
no tener mercado para sus azucares de alta calidad. Aquellos hacendados azucareros dueños de ingenios obsoletos por su atrasada maquinaria, sin embargo, pudieron concentrar sus esfuerzos en el sector agrícola (Moreno Fraginals 445-446). La siembra, el corte, la molienda y el procesamiento mínimo del azúcar para ser exportada a Estados Unidos, era todo lo que, al parecer, iba quedando de la agroindustria azucarera cubana decimonónica.

Hay que tener en cuenta, sin embargo, que además de estos cambios, durante las últimas tres décadas del siglo XIX ocurrieron otros acontecimientos que contribuyeron a la transformación del mundo azucarero. Aunque la guerra de los Diez Años (1868-1878), la de Secesión en Estados Unidos (1861-1865) y la Franco-Prusiana (1870-1871) en Europa prolongaron la vida de la sacarocracia cubana — debido a la subida de la demanda y de los precios del azúcar - un alto porcentaje de esta clase, que había hipotecado sus propiedades para poder adoptar las nuevas tecnologías, para finales del siglo, había desaparecido. Sólo algunas pocas familias criollas junto a acaudalados comerciantes españoles pudieron invertir en lo que ahora se denominaría el central: una fábrica de azúcar de grandes dimensiones que, debido al avance tecnológico de las maquinarias, además de moler más caña y extraer más sacarosa de cada planta que exprimía también necesitó de más tierras para poder suplir su demanda. Con la construcción de estos llamados centrales el pequeño y atrasado ingenio perece, consolidándose de esta forma la industria: menos cantidad de fábricas, pero una mayor producción de azúcar.

A diferencia del sector industrial, sin embargo, la base agrícola en este período apenas se moderniza, por lo que se crean grandes contradicciones entre ambas ramas de la industria. La rentabilidad de los nuevos centrales, que dependía de la moledura de una 
gran cantidad de caña, se ve amenazada ante un sector agrícola atrasado, incapacitado de suplirles con la cuantía requerida. Sumado a esto, un largo y complejo proceso para abolir definitivamente la esclavitud llega a su último estadio en 1880 con la ratificación de la Ley del Patronato, un proyecto que estipulaba la emancipación gradual de los esclavos ${ }^{173}$. Como consecuencia, progresivamente se irá creando una división entre estos dos procesos azucareros —el industrial y el agrícola — para lograr abastecer a los centrales con la cantidad de caña necesaria y con ello producir una proporción de azúcar que les fuera rentable.

La figura del colono $^{174}$, como cultivador de la gramínea que vende luego su cosecha al central, irá ganando importancia en el mundo del azúcar durante este período. Además de los antiguos sacarócratas criollos que ante la imposibilidad de participar en el sector industrial habían destinado sus tierras a la siembra de la caña, también desempeñarán esta labor campesinos menores, inmigrantes blancos —en su mayoría españoles- e incluso antiguos esclavos, una vez que quedó abolida la esclavitud (Santamaría, "Colonos" 134) Por su parte, ésta última, unida a las demandas del gran central, trajo como consecuencia el empleo temporal — durante la zafra - de miles de trabajadores asalariados encargados de realizar el corte de la caña.

A pesar de que a finales del siglo la Guerra de independencia (1895-1898) tuvo drásticos efectos en la agroindustria azucarera cubana, el hecho de que Estados Unidos se

\footnotetext{
${ }^{173}$ El Patronato estipulaba la abolición gradual de la esclavitud en un período de ocho años. En 1886, no obstante, dos años antes de que finalizara este período, fue abolida esta ley y con ella definitivamente la esclavitud.

${ }^{174}$ Para más información sobre el surgimiento de los colonos y su importancia en la sociedad cubana de la época puede consultar "Colonos. Agricultores cañeros, ¿clase media rural en Cuba? 1880-1898" (1998) de Antonio Santamaría García y "La agricultura y los colonos" en La manos en el dulce (2004) de Oscar Zanetti Lecuona.
} 
involucrara y terminara interviniendo militarmente la Isla (1899-1902) propició un nuevo crecimiento en el sector. Tras la instauración, durante el período de intervención, de algunas disposiciones de naturaleza económica se firmó, en 1902, el Tratado de reciprocidad comercial entre ambos países, con el cual Cuba quedó definitivamente integrada a un mercado preferencial (Zanetti, "Las manos en el dulce" 16). A raíz de estas medidas, unidas a la incorporación de la Enmienda Platt (1901) en la recién promulgada Constitución cubana — que le daba derecho a Estados Unidos a intervenir militarmente la Isla si sus intereses se veían amenazados, entre otras prerrogativas-, grandes firmas y sociedades norteamericanas comenzaron a invertir en el lucrativo negocio del azúcar. Además de adquirir, remodelar o construir centrales azucareros de gran capacidad, también comprarán vastas extensiones de tierra, primordialmente en la zona oriental del país, donde ésta era aún virgen y abundante y a la cual se tenía acceso ahora gracias a la construcción del ferrocarril central — también a cargo de una firma norteamericana- (Zanetti, "Las manos en el dulce" 16-17) $)^{175}$.

La creación de estos latifundios, más allá de garantizar la materia prima, respondía a un intento, por parte de los centrales, de independizarse de los colonos autónomos para poder controlar los precios de la caña. Aunque la mayoría de estas tierras serían arrendadas a labradores para el cultivo de la gramínea, su condición de arrendatarios, entre otros vínculos que les creaban dependencia, los supeditaba al central (Moreno Fraginals 488-489; Zanetti, "Las manos en el dulce" 17-18). Con esta práctica los dueños de fábricas de azúcar lograban ejercer un control, sino general, al menos sobre

\footnotetext{
${ }^{175}$ Para más información sobre el crecimiento del Imperio azucarero norteamericano a raíz de la intervención de Estados Unidos en la Guerra de Independencia cubana en 1898, puede consultar la obra de April Merleaux mencionada previamente en la nota 164.
} 
una parte del colonato.

El interés norteamericano en la agroindustria azucarera cubana, no sólo como comprador sino como dueño de centrales y de latifundios, unido a acontecimientos internacionales que resultaron beneficiosos, propició que esta nación, durante las primeras décadas del siglo $\mathrm{XX}$, continuara acaparando poco a poco la producción del dulce en la Isla. El terrible impacto que la Primera Guerra Mundial (1914-1918) tuvo sobre los países europeos productores de azúcar de remolacha ofreció a Cuba la posibilidad de abastecer este mercado y con ella se produjo un nuevo crecimiento de la industria. Los capitales norteamericanos atraídos ante esta coyuntura participaron en este proceso de expansión construyendo y comprando más fábricas de azúcar. En 1920, tras una drástica caída del precio del dulce, propiedades de varios hacendados y colonos incapaces de afrontar la crisis —en su mayoría cubanos o españoles - terminaron también en manos estadounidenses.

Sumado a esta tendencia expansionista, las grandes inversiones que las corporaciones norteamericanas habían hecho en la zona oriental del país propiciaron que se comenzara a perfilar una notable disparidad entre las regiones azucareras de la Isla. En el Occidente, mayoritariamente en manos cubano-españolas, quedaban los antiguos centrales, de menor capacidad, y extensiones de tierra mucho más limitadas dedicadas al cultivo de la caña. En el Oriente, por su parte, se concentraban las grandes fábricas y los grandes latifundios norteamericanos. La industria azucarera cubana se rendía ante el poder del gigante del Norte.

Esta constante presencia de los Estados Unidos en Cuba, no sólo en el sector azucarero, sino también en otras ramas de la economía, causando un extraordinario 
impacto en la política y en la sociedad cubanas, hizo que surgiera un sentimiento antiimperialista, marcadamente nacionalista, que terminó reflejándose en la literatura del azúcar. Unido a la pérdida de soberanía, a crisis azucareras que golpearon profundamente el país, a hacendados arruinados y colonos controlados, existía este ejercito flotante de trabajadores, dedicados en su mayoría al corte de la caña, que hallaba empleo temporal en los meses de la zafra, pero que durante el resto del año se debatía ante el tiempo muerto $^{176}$. El malestar que el nuevo mundo azucarero infligía en varias capas de la sociedad no se hizo esperar y muy pronto aparecieron textos representativos de un nuevo discurso anti-azúcar, que se distinguió, particularmente, por su tendencia a la melancolía.

En su preludio en "Nicolás Guillén: ingenio y poesía"177, Benítez Rojo analiza y contrasta el libro Los ingenios, de Cantero, y el poema La zafra (1926) ${ }^{178}$ de Agustín Acosta (1886-1979). Mientras que el primero, como indica este ensayo y también el acápite anterior del presente estudio, se inscribe dentro del discurso totalizador del azúcar, el segundo lo hace al de la resistencia. A diferencia de la obra de Cantero continúa Benítez Rojo- que glorifica la máquina, como símbolo de la industria azucarera, y resalta su capacidad civilizadora, La zafra es el lamento de aquellos quienes, durante la época republicana, sufren su opresión (145).

El rechazo de Acosta hacia el poderío azucarero va a estar acompañado, en este caso, de un tono antiimperialista, a raíz del papel que Estados Unidos desempeñaba en la agroindustria azucarera cubana y del poder, en general, que ejercía sobre la Isla. Además

\footnotetext{
${ }^{176}$ A diferencia de zafra o molienda, el tiempo muerto indica los meses de inactividad de la industria azucarera.

${ }^{177}$ La isla que se repite (2010).

${ }^{178}$ Poema dividido en Pórtico, Preludio, dieciocho Cantos y Postcenio.
} 
de esta obra, "El poema de los cañaverales" $(1926)^{179}$ de Felipe Pichardo Moya (18921957), con una postura similar de denuncia a los males que infligía esta industria, también es analizado en este estudio. La oposición al latifundio y al monocultivo y un latente repudio hacia la presencia norteamericana en la nación reflejaba en estos poemas, según Benítez Rojo, el sentir de la época ${ }^{180}$.

Tras una lectura de ambas obras, más allá del tono de denuncia, al que regresaré en los próximos párrafos, resalta el papel que la caña desempeña en el paisaje, como parte de la simbología nacional. A diferencia de los discursos anti-azúcar antes analizados, que negaban la presencia de la gramínea o que no la percibían como uno de los elementos esenciales de los campos cubanos —en cuanto a que no formaban parte de la naturaleza edénica de la Isla— hay en estos versos una apropiación e incorporación de la caña de azúcar como símbolo identitario de la nación. Tras algo más de un siglo de presencia en la campiña los cañaverales han pasado a ser un componente emblemático del paisaje cubano y, por ende, un atributo de la cubanía. En las estrofas siguientes, fragmentos de ambos poemas, se puede apreciar como los dos poetas asumen esta apropiación. En el Canto II, titulado "Mediodía en el campo", Acosta escribe:

$$
\text { .... El aire }
$$

es un cristal azul que transparenta toda la gama verde de los árboles; y sobre toda la esmeralda inmensa, atlántica de los cañaverales. (28-32)

\footnotetext{
${ }^{179}$ Poema dividido en doce secciones que se pueden leer como poemas independientes.

${ }^{180}$ Benítez Rojo explica que en este período también se publicaban escritos de prensa representativos del malestar socioeconómico de la época. Como ejemplo menciona los artículos económicos de Ramiro Guerra y Sánchez en el Diario de la Marina, recogidos después en el libro Azúcar y población en las Antillas (1927). Para más información sobre escritos de esta índole, también se puede consultar La República: dependencia y revolución (1969), de Julio de Riverend.
} 
Mientras que en la sección III del poema de Pichardo se lee:

Cañaverales: vuestras mareas de esperanzas Inundan las maniguas y la loma y el llamo, Y poco a poco alzáis al cielo vuestras lanzas Desde el pueblo naciente hasta el confín lejano. (1-4)

Lo más significativo no está precisamente dado en la incorporación de la caña como un elemento armónico dentro del paisaje nacional, sino más bien en la similitud que guardan ambos cuadros descriptivos. La sensación de infinidad y movimiento que trasmiten estos dos poemas, lograda a través de las palabras "inmenso", "inundan", "aire" y "mareas", hace que los cañaverales se imaginen como océanos de cañas mecidos por el viento, una escena que se irá convirtiendo en una imagen común de la poesía del azúcar. Por otra parte, también se encuentran las referencias cromáticas en las palabras "esmeralda" y "esperanza", tonos de verde que usan, indistintamente, ambos poetas y que se van integrando a la paleta de colores con la que se dibuja el paisaje de la campiña.

Además de estas alusiones, es importante señalar que ambos poetas perciben a la caña como una planta bondadosa, motivo de orgullo, y que ambos expresan su amor hacia la gramínea. Más allá del indiscutible valor económico que le ofrece a la nación una vez que se transforma en azúcar, hay un vínculo sentimental, afectivo —condicionado también por la historia - entre el pueblo cubano y la caña, que hace que a esta última se le identifique muy claramente con la cubanidad. Pichardo, por ejemplo, a pesar de la presencia norteamericana en la industria, expresa su amor a las cañas "porque habla[n] en español" (25) y entiende que

So[n] la muestra viviente del prodigio cubano, que tras de cada guerra pone sobre la tierra 
la nueva floración! $(8-11)^{181}$

Es importante destacar que la percepción que se tiene en esta época sobre la gramínea también ha estado influenciada por la separación de los dos sectores del proceso azucarero —el agrícola y el fabril—. Sí durante la era colonial el paisaje azucarero se rechazaba por asociarse, no sólo a los horrores de la esclavitud, sino también a la africanización, en las primeras décadas del siglo XX eran en su mayoría campesinos blancos los que se dedicaban a la siembra de la caña. Había, como bien apunta Santamaría ${ }^{182}$, colonos de diversas clases y razas, pero eran los pequeños y medianos agricultores, de descendencia cubano-española, tanto criollos como inmigrantes, los que representaban un porcentaje mayor. La caña, al igual que la sociedad de la época, sufrió, a partir de la abolición de la esclavitud, un proceso de blanqueamiento y se percibió, gracias al colono - y a diferencia del negro - como símbolo de la cubanidad. En el caso de estos poemas también es un elemento que se incorpora al discurso de la resistencia antiimperialista, por ser el campesino, representativo de la hispanidad, el encargado de la siembra de los cañaverales y no "los rubios ingenieros de atlético porte" (3) ${ }^{183}$ o los de ojos azules, de quienes se ignoraba el color de su alma ${ }^{184}$ — versos con los que Pichardo y Acosta describían a los estadounidenses.

Unido al colonato, el cambio de percepción que se tiene sobre la caña de azúcar, a partir de las últimas décadas del siglo XIX, también es debido al papel que jugó la

\footnotetext{
${ }^{181}$ Estos versos pertenecen a la sección XII del poema.

${ }^{182}$ En “Colonos. Agricultores cañeros, ¿clase media rural en Cuba? 1880-1898” (1998).

${ }^{183}$ Verso tomado del Poema IX de Pichardo.

${ }^{184}$ Alusión al Canto XV del poema de Acosta, titulado "La sombra del caudillo". En el poema se lee: "Tenían los ojos azules. . .Se ignora el color de sus almas. ..".
} 
industria azucarera dentro de las Guerras de Independencia. Aunque la Primera Guerra fue iniciada por Carlos Manuel de Céspedes, el dueño de un pequeño ingenio, esta fábrica era prácticamente improductiva y el resto de los cubanos que inicialmente se unieron a él no eran, en su mayoría, hacendados azucareros (Moreno Fraginals 466). La gran sacarocracia cubana no fue la protagonista de este evento; muy por el contrario, fueron los integrantes de una clase criolla relativamente poco próspera, a favor de la abolición de la esclavitud y, por ende, en contra de los intereses azucareros, quienes se lanzaron a luchar por la independencia de la Isla. El carácter anti-azucarero de la contienda queda evidenciado en la quema de miles de hectáreas de caña de azúcar y la destrucción de ingenios como parte de la estrategia militar del Ejercito Libertador, algo que pasó a la historia con el nombre de tea incendiaria y a la que tanto Acosta como Pichardo hacen alusión.

"El incendio aleteaba en las mentes opresas/y en los ojos criollos refulgían las llamas" (15-16), escribe Acosta ${ }^{185}$ rememorando los deseos independentistas de los iniciadores de la guerra. Este afán de los libertadores se materializará después con la destrucción de los campos de Cuba, incluidos los cañaverales, y de los ingenios azucareros, imagen que se recoge en las siguientes estrofas del poema.

Y un infierno dantesco retorcía sus lenguas

En las selvas inmensas, en los campos de caña;

Derruía los largos barracones infectos;

De los chatos ingenios oxidaba las máquinas. . . (21-24)

Era todo de púrpura en las foscas maniguas. . .

Y en las noches azules de las altas montañas

Una aurora de fuego su anticipo exprimía

A la luna que el júbilo de su aplauso goteaba. . . (25-28)

${ }^{185}$ Canto IX del poema La zafra, titulado "Toque de clarín”. 
Pichardo, por su parte, prefiere el uso de la prosopopeya para destacar el papel que jugó la destrucción de la industria azucarera durante la guerra. Con este recurso se justifica e idealiza - la tea incendiaria, al presentar la quema de los campos como un sacrificio de la naturaleza a favor de la independencia de la Isla.

¡Por la patria irredenta ofrendasteis la vida!

¡Vuestras llamas ardientes una noche quizás salpicaron de sangre la silueta fornida del invasor, y el fuego la agigantaba más! (13-16)

Cabe destacar que la alusión a la tea incendiaria no es un fenómeno literario que se inició en esta época. De hecho, tampoco fueron los mambises los precursores de esta práctica. Antes de las guerras de independencia ya los esclavos quemaban campos de caña como símbolo de rebeldía. En la poesía cubana decimonónica, por sólo poner dos ejemplos, María Santa Cruz (1789-1852) y Mercedes Matamoros (1851-1906) hacen referencia a este fenómeno en algunos de sus versos ${ }^{186}$. La primera, adoptando una postura cercana a la de la sacarocracia, lamenta ver los campos de caña reducidos a la nada bajo las terribles llamas ${ }^{187}$; mientras que la segunda, inscribiéndose al discurso de resistencia a la plantación, exhorta a la quema de los cañaverales manifestando que se trata de un acto no sólo vengativo sino también purificador ${ }^{188}$.

En el caso de los poemas de Acosta y Pichardo se puede concluir que, a pesar de representar la caña durante este período la opulencia de la sacarocracia, fue justamente en

\footnotetext{
${ }^{186}$ Referencia a los poemas "Adiós a la Macagua" de María Santa Cruz y "La canción de las cañas" de Mercedes Matamoros.

${ }^{187}$ En el poema se lee: "Vi nuestros campos un día/ presa de terribles llamas/ allí levanté a la virgen/ mi fervorosa plegaria/ viendo el voraz elemento/ reducirlos a la nada".

${ }^{188}$ En el poema se lee: “¡Ven! ¡llama destructora!, y arrasa vengativa/ desde el lozano tronco hasta el penacho en flor/ . . . tu fuego solamente purificar podría/ el aire que el delito nefando envenenó" (41-46).
} 
esta imagen constante de cañaverales en llamas donde la gramínea no sólo cobra un indiscutible protagonismo, sino que se inserta definitivamente a la epopeya nacional. Cualquier evocación histórica de las glorias fundadoras de la nación, tendrá que, a partir de este momento, reproducir esta imagen donde la caña dejaba definitivamente de ser extranjera para convertirse en sinónimo de patria.

Es significativo acentuar que además de las referencias a las Guerras de Independencia, tanto en La zafra como en "El poema de los cañaverales" se realiza una especie de evocación histórica que se vincula a la situación sociopolítica del presente. La apropiación de la caña de azúcar como símbolo identitario de cubanía, no impide que tanto Acosta como Pichardo representen el arbitrario papel que la agroindustria azucarera ha jugado en la Isla. A ella se le debe la riqueza y el crecimiento de la nación, pero también ha dado ella los capítulos más oscuros de la historia cubana. Los horrores de la esclavitud $^{189}$ y las guerras, las crisis económicas tras la caída del precio del azúcar ${ }^{190}$ y la injerencia estadounidense ${ }^{191}$ son algunos de los temas tratados en estas obras, que evidencian el conflictivo rol desempeñado por la caña de azúcar en la nación.

En el caso del poema de Acosta, también se exponen las pésimas condiciones en las que vive la mayoría de los campesinos ligados al sector azucarero — sobre todo durante el tiempo muerto-. A diferencia de los cantos que narran las hazañas del

\footnotetext{
${ }^{189}$ En particular el Canto VIII de Acosta, titulado "Los negros esclavos", y la sección VI del poema de Pichardo describen los horrores de la esclavitud negra en Cuba.

${ }^{190}$ En los Cantos XIII, "Loa arbitraria al azúcar", y XVII, "La danza de los millones", Acosta hace una clara referencia a las crisis económicas que azotaron a la Isla debido a la caída del precio del azúcar en el mercado internacional.

${ }^{191}$ Aunque la crítica antiimperialista se puede apreciar a lo largo de ambos poemas, el Canto XVI de Acosta, titulado "Los centrales de hoy", y las secciones IX, X y XI de Pichardo son quizás los más representativos.
} 
Ejercito Libertador, con los cuales tanto la caña y como los hombres son inscritos a la epopeya nacional, los cantos de corte costumbrista ${ }^{192}$ que aparecen en este poema se alejan de la épica para ofrecernos un análisis etnográfico del campesinado azucarero cubano. Acosta observa y detalla el estilo de vida de esta clase. Su rutina diaria, desde que amanece y se incorpora al trabajo hasta que regresa de noche a su bohío; sus relaciones familiares e íntimas; los instrumentos que utiliza y la manera en la que realiza las labores agrícolas; entre otros, son representados en estos versos donde el protagonismo no radica en la grandeza de las gestas sino en la capacidad de sobrevivir una vida llena de adversidades y miserias.

Es importante subrayar, que a pesar de los episodios épicos, son justamente estos cuadros costumbristas y la abierta postura antiimperialista los que marcan el tono de la obra. De hecho, la rememoración de los héroes y las guerras independentistas no logran escaparse del sentir melancólico de la época. Hay, al igual que en el poema de Pichardo, un deseo de cambio, la alusión a una revolución que terminará transformando positivamente la nación cubana, un aire de esperanza que se desvanece, justamente, porque la sociedad ha quedado adormecida y los héroes son parte de epopeyas pasadas. Aunque el despertar de la conciencia política social de la nación es claramente la intención de estos poetas, tanto en La zafra como en "El poema de los cañaverales" la posibilidad de una transformación, más allá del deseo, no se vislumbra como un acto inmediato o verdaderamente posible. La caña, a diferencia de la máquina que se asocia al descomunal y monstruoso central azucarero norteamericano, ha cobrado su protagonismo

\footnotetext{
${ }^{192}$ En los siguientes cantos Acosta describe el modo de vida de los campesinos azucareros: Canto II, "Mediodía en el campo"; Canto III, "El corte de caña"; Canto V, "Aguafuerte criolla" y Canto VI, "Las carretas en la noche".
} 
como símbolo identitario de la nación; ya es, sin duda, cubana, pero tendrán que bajar de la Sierra Maestra los jóvenes del Ejército Rebelde encabezados por la figura de Fidel Castro, para que se despoje de la melancolía y recupere su espacio en la épica nacional.

\subsection{EL AZÚCAR EN LA REVOLUCIÓN: LA REESCRITURA DE LA HISTORIA Y EL HÉROE AZUCARERO EN EL METARRELATO REVOLUCIONARIO Y LA MIRADA DIFERENTE}

En el primer capítulo de este estudio expliqué brevemente como a partir de 1959 el gobierno revolucionario se adscribió al discurso de resistencia a la plantación. Durante los primeros cuatro años de la Revolución castrista predominó un discurso económico que abogaba por la industrialización y la diversificación de la economía. La industria azucarera se convirtió durante este período en una especie de chivo expiatorio al cual se le inculpaban los males de la nación, debido, sobre todo, a la dependencia que esta industria había creado con los Estados Unidos. El demonio azucarero, además de ser durante estos años severamente criticado, sufrió una importante reducción producto del desmantelamiento de un alto número de caballerías destinadas a la siembra de la caña (Sanguinetty 29). Esta política ${ }^{193}$, encabezada por Ernesto "Che" Guevara, trajo como resultado la disminución de la producción azucarera durante las zafras de 1962 y 1963, con su consecuente crisis para la economía cubana. A partir de este momento, el discurso anti-azúcar se moldea y se empieza a representar a esta industria como un elemento clave para lograr la diversificación (Santamaría, "La revolución” 698). Ya Estados Unidos había eliminado por completo la cuota azucarera, pero el gobierno cubano había

\footnotetext{
${ }^{193}$ Cabe destacar que aunque el discurso anti-azúcar está presente desde el inicio de la Revolución la política económica de Ernesto Che Guevara se inicia a partir de 1960.
} 
encontrado en la Unión Soviética y los demás países del CAME un nuevo comprador.

Estas dos posturas antagónicas que mantiene el régimen hacia la agroindustria azucarera van a estar representadas en la producción cultural de la oficialidad. A sólo unos días del triunfo de la Revolución, al recién creado Departamento Cinematográfico ${ }^{194}$ se le comisionaron dos documentales relacionados a las dos grandes primeras reformas que proponía el gobierno: la Agraria y la Urbana. El primer documental, Esta tierra nuestra (1959), dirigido por Tomás Gutiérrez Alea, se encargaría de comunicar a las masas, en un lenguaje asequible, la necesidad de la Reforma Agraria. Dentro de los males que sufría el campesinado cubano, según esta obra, la indiscriminada distribución de la tierra y las drásticas consecuencias de la monoproducción eran unos de los que ocasionaban mayor perjuicio. El latifundio azucarero controlando grandes extensiones de tierras que pudieran ser utilizadas para otros cultivos y la casi exclusividad del azúcar como producto exportable, imponiéndole meses de desempleo a una parte de la población, hacían de la industria azucarera un agente culpable.

Para lograr trasmitir este mensaje de una manera eficiente, el documental, más allá de las imágenes, se va a apoyar en un texto ${ }^{195}$, escrito por Titón y narrado por un narrador extradiegético, que divide la Historia cubana en dos etapas diferentes. En un primer período, perteneciente al pasado, los campesinos eran maltratados constantemente y tanto los gobiernos como las autoridades locales tomaban parte de esta explotación —a favor de los intereses de la clase pudiente—. La economía de la nación, por su parte,

\footnotetext{
${ }^{194}$ Este departamento se creó dentro de la Dirección de Cultura del Ejercito Rebelde y el 24 de marzo de 1959 ya se convertía en el Instituto Cubano del Arte e Industria Cinematográficos (ICAIC).

${ }^{195}$ Copia del texto íntegro se puede encontrar en la edición número 15 de la revista Lunes de Revolución, fechada el 22 de junio de 1959.
} 
dependía del monocultivo del azúcar y de compañías extranjeras; mientras que a la Isla y a sus habitantes el subdesarrollo los marcaba profundamente. En la segunda etapa, sin embargo, los campesinos, unidos al gobierno revolucionario, comenzarían a construir un futuro donde la justicia y la prosperidad fuera para el disfrute de todos, algo que se lograría, según el narrador, a través de la Reforma Agraria. La industria azucarera, conforme a este discurso, con sus grandes latifundios y su tiempo muerto era parte de la etapa anterior.

Esta manera de dividir la Historia de Cuba en dos momentos históricos antagónicos, donde el pasado pre-revolucionario es demonizado, mientras que al tiempo de la Revolución se le imprime un carácter humanista y mesiánico, ya fue analizada en los primeros capítulos de este estudio cuando se examinaron diferentes textos concernientes a la reestructuración azucarera. Esta tierra nuestra, en este caso, sirve como prueba de que este acercamiento histórico ha existido desde los inicios de la Revolución y de que el azúcar ha jugado un papel esencial dentro de él. Se trata, de cierta manera, de lo que Michel de Certeau definiera como el discurso de la separación dentro del proceso de la escritura de la Historia ${ }^{196}$.

Según este historiador, dentro de la historia occidental, cada tiempo nuevo construye un discurso que trata como muerto al tiempo predecesor. Es un proceso donde se crea y acentúa una diferencia entre el presente y el pasado, en un afán por ser otro, por no ser lo mismo que se era, y donde el pasado, como objeto pasivo, sufre una nueva interpretación. Este procedimiento de la escritura del pasado $-\mathrm{o}$ más bien de su reescritura — se va a apoyar en un poder político que ansía la creación de un lugar propio

\footnotetext{
${ }^{196}$ Referencia a la obra La escritura de la historia (1975).
} 
donde pueda legitimarse; un poder que, ulteriormente, decidirá que capítulo del pasado debe ser comprendido — retomado - y cual debe ser olvidado (16-20). En general, el discurso de la separación se puede asociar al concepto de memoria monumental propuesto por Nietzsche y analizado en este estudio previamente.

Para ilustrar esta idea, Certeau inicia su obra rememorando el famoso grabado del artista holandés Jan van der Straet (1523-1605) ${ }^{197}$, con el que se inmortalizó la llegaba de Américo Vespucio al Nuevo Mundo. En el grabado, aparece el explorador italiano de coraza, como un cruzado, de pie frente a una mujer indígena, quien reposa desnuda sobre una hamaca. La imagen, según Certeau, tiene un valor casi mítico, porque representa el inicio de un nuevo funcionamiento occidental de la escritura. Más allá del asombro de Vespucio (el Viejo Mundo) ante la terra incognita y exótica, aún por explorar representada en el cuerpo desnudo, pasivo, de la mujer-, Certeau afirma que lo que se esboza en esta obra es la colonización del cuerpo por el discurso del poder. A partir de esta escena inaugural, comenzará Europa la escritura conquistadora que impregnará en América el deseo occidental (11), separándose, o más bien borrando, el legado histórico amerindio.

A través de esta lectura alegórica de la obra de Van der Straet, Certeau no sólo hace patente la necesidad que tiene todo nuevo poder de reescribir la Historia, persiguiendo un afán legitimador, sino que descubre la esencia tendenciosa y destructora de este discurso. Reemplazada esta imagen, siglos más tarde, dentro del contexto de la Revolución Cubana, por las diversas fotografías que documentaron el recorrido de la

\footnotetext{
${ }^{197}$ Este pintor manierista también es conocido como Stradamus. La obra a la que hago referencia se titula América (circa 1575), una pieza bastante emblemática que ha despertado la curiosidad de otros académicos, entre ellos Louis Monstrose y Margarita Zamora, quienes la han analizado en sus estudios.
} 
caravana del Ejército Rebelde ${ }^{198}$, desde Santiago de Cuba hasta su entrada triunfal en la Ciudad de la Habana, sería el nuevo orden sociopolítico y económico que se intentaba implantar-encabezado esta vez por la figura de Fidel Castro- el que necesitara articular un discurso que lo validara y, para ello, reescribiría la Historia, en este caso, de una nación.

El paso de la caravana a lo largo de la Isla, recogido en las fotografías, serviría como imagen simbólica y premonitoria de la colonización de Cuba por el discurso del nuevo poder. A la Isla, objeto pasivo que se supone escrito pero que debe ser reinterpretado, la caravana, sujeto encargado de realizar esta interpretación, le irá escribiendo una Historia con la cual le estampe el deseo de la Revolución. De esta reapropiación histórica, impregnada de una fiebre conquistadora —en palabras de Certeau-, no se escapará el capítulo azucarero cubano que, una vez reescrito, será incluido en el metarrelato revolucionario. El documental Esta tierra nuestra, dentro de este proceso, pudiera ser tomado como una de las primeras piezas que se inserta a la Historia narrada por la Revolución y su postura anti-azúcar, un elemento esencial del discurso de la separación que propone.

Cuando comienza a ser evidente que el país no estaba preparado para asumir la política de demolición azucarera, no de una manera tan abrupta y sin que hubiera otras ramas económicas que pudieran reemplazar a esta industria, el discurso anti-azúcar se va a abandonar y será substituido por un discurso que, aunque a favor de la diversificación y

\footnotetext{
${ }^{198}$ Esta caravana se conoce en la Historia como Caravana de la Libertad y comprende el itinerario que hicieran Fidel Castro y el resto de las tropas del Ejercito Rebelde al triunfo de la Revolución, desde el Oriente hasta el Occidente del país. Con este mismo nombre se ha publicado un libro, por Luis Báez y Pedro de la Hoz, donde se narra el recorrido de la caravana incluyendo testimonios de algunos de sus protagonistas y las famosas fotografías.
} 
la industrialización, abogará por la supremacía del azúcar en la economía cubana. A partir de 1964 se comenzará a hablar de la importancia que tiene el azúcar para diversificar e industrializar el país y se pondrá de moda el slogan "azúcar para crecer". Ya desde esta fecha se empieza a concebir la idea de producir diez millones de toneladas de azúcar, por lo que en la agroindustria azucarera se realizarán algunas inversiones para ampliar tanto la capacidad del corte de caña y su transporte, como la de su molienda y la elaboración del dulce (Sanguinetty 47). Además de este nuevo programa económico, llamado Plan Perspectivo Azucarero (1965-1970), también se va a crear el Movimiento Millonario ${ }^{199}$ de Cuba, donde se incentivaba la emulación entre las brigadas de macheteros hasta alcanzar cortar el millón de arrobas de caña. Es bajo este contexto que se produce el documental Oro de Cuba (1965), dirigido por Alejandro Saderman y producido por el Instituto Cubano de Arte e Industria Cinematográficos (ICAIC) ${ }^{200}$.

A diferencia de Esta tierra nuestra, Oro de Cuba no es una obra que se adscribe al discurso anti-azúcar. Muy por el contrario, bajo la nueva política económica adoptada por el gobierno, Cuba tenía que continuar siendo azucarera. El documental, no obstante, sí sigue las mismas premisas del discurso de la separación que se viera en la obra de Titón. Si el primero mencionaba al azúcar como uno de los males de antaño, para concentrarse mayormente en la redistribución de la tierra, en este segundo se va a revisar

\footnotetext{
${ }^{199}$ Aunque el Movimiento Millonario de Cuba fue creado el 3 de marzo de 1965, ya desde 1963, apadrinadas por Ernesto "Che" Guevara y por el dirigente comunista Ursinio Rojas, se realizaban competencias de corte de caña entre los macheteros.

${ }^{200}$ Esta institución, además de ser creada expresamente para articular el discurso del régimen, fue también durante muchos años la única autorizada en producir cine dentro de la Isla. De esta manera se monopolizaba la industria fílmica y se garantizaba el control de toda la producción cinematográfica.
} 
- y reescribir - el capítulo azucarero de la nación ${ }^{201}$.

Muy similar al discurso que Fidel Castro pronunciara en el año 2002, donde anunciaba oficialmente la reestructuración de la agroindustria azucarera, y al Documento programático (ambos textos analizados al inicio de este estudio), en el documental se va a delinear un marcado contraste entre la cara oscura de la historia del azúcar, durante el período colonial y republicano, y el nuevo capítulo histórico que en estos momentos, gracias a la Revolución, se estaba construyendo. El trabajo esclavo, tanto del negro como del obrero asalariado — sin el que, según Fernando Ortiz en este documental, no hubiera sido posible fundarse ni mantenerse la industria—; la opulencia de una clase parasitaria que vivía del trabajo de otros, "quienes en muchos casos ni siguiera se dignaban a vivir en los palacetes del pobre país tropical" (00:23:51-12) — según la reclamaba la voz off del narrador, aludiendo a los sacarócratas extranjeros-; la miseria de quienes producían la caña; el tiempo muerto; el desalojo campesino y la injerencia norteamericana frustrando a la joven República; entre otros, eran males que con el triunfo revolucionario habían quedado atrás. También al tiempo pasado pertenecían los gobernantes corruptos, vendidos a los intereses norteamericanos y de la burguesía nacional; los engañosos y momentáneos períodos de vacas gordas, seguidos de crisis que terminaban hundiendo a los desposeídos cada vez más en la miseria; las revoluciones frustradas y los asesinatos impunes de líderes revolucionarios, comandados, en ocasiones, por los propios gobiernos.

Al nuevo capítulo, por su parte, pertenecía la verdadera Revolución, aquella que durante el siglo se había estado gestando por las figuras de Julio Antonio Mella, Antonio

\footnotetext{
${ }^{201}$ Dentro de la literatura, en el poema "Pequeña historia de Cuba" (1971), Eliseo Diego también hace una revisión - y reescritura - del capítulo azucarero de la nación.
} 
Guiteras y Jesús Menéndez — todos asesinados y convertidos en mártires de la nación— y, unos años más tarde, por el movimiento estudiantil, al cual perteneciera Fidel Castro y otros integrantes del actual gobierno revolucionario. El Asalto al Cuartel Moncada, el Desembarco del Granma y la lucha armada en la Sierra Maestra, encabezados por el ahora máximo líder, son hechos que desembocarán en el triunfo de la Revolución y en la creación de un gobierno que responde a los intereses de la clase trabajadora. "Como el pueblo se ha reconocido en este nuevo gobierno [reclama la voz en off del narrador] ... respaldará sus actos $[\mathrm{y}]$ celebrará jubiloso las nacionalizaciones de las empresas yanquis. Cuba es al fin cubana y marcha hacia el socialismo" (00:33:12-27). Esta división histórica, como ya se ha señalado, alimentaba mitos demonizadores y mesiánicos para ofrecerle un sentido de continuidad histórica a la entonces joven Revolución. Se trataba de la reescritura de la Historia de la nación cubana, particularmente de su capítulo azucarero, a través del discurso de la separación.

Más allá de este discurso silenciador y apologético, uno de los aspectos más importantes de este documental es la substitución del tono melancólico, predominante en los discursos de resistencia a la plantación que se habían producido durante la era republicana - predecesores inmediatos de este discurso-, por uno excesivamente triunfalista. Las nuevas circunstancias económicas exigían que se abandonara la postura anti-azúcar y la política de la demolición azucarera, para que se abrazara ciegamente un discurso pro-industrial y totalizador a favor del azúcar. Como resultado, la percepción negativa - e incluso monstruosa - de la industria azucarera que se había manifestado durante la era colonial y republicana se invierte y a partir de este momento se enviste con un nuevo significado. "El azúcar [continúa más adelante el narrador] ya no es la 
impalpable y atroz cadena que ata al pueblo cubano, ya no conoce vacas flacas, ni amenaza con el tiempo muerto, ni pertenece a compañías extranjeras. Ya nada frena el desarrollo de la técnica. Nada impedirá la aplicación de los más modernos adelantos” (00:35:16-36).

En cuanto al paisaje azucarero, la adopción de la nueva maquinaria lo convertía en un locus industrial, donde, a diferencia del paisaje intermedio propuesto en las litografías de Los ingenios, la industria azucarera no se integraba armoniosamente a la naturaleza edénica de la Isla. Los cañaverales y, sobre todo, el trabajador azucarero y la máquina, son los protagonistas de los cuadros que se presentan en este documental, que nada tienen de bucólicos. "El paisaje azucarero empieza a dibujarse también con estos hierros que irán aumentando cada vez más, para relevar a los hombres de trabajos tan duros" (00:34:36-46). Unos segundos antes de que se escuche la voz del narrador manifestando esta observación a favor de la maquinaria, en la pantalla aparece un hombre conduciendo una alzadora de caña. Uno de los aspectos más significativos de esta toma, es que la enorme rueda de la alzadora en primer plano empequeñece la figura humana, logrando que la atención del espectador se centre en la máquina. En la próxima escena, a través de un plano general, se va a observar una hilera de alzadoras que van pasando por delante de la cámara, imagen que se puede asociar al "parque de máquinas" que visualizaba Benítez Rojo cuando comentaba acerca del conjunto de litografías que conformaban Los ingenios, aunque en este cuadro no había cabida para el "verde y apacible paisaje de la campiña". Los conductores, al igual que en la escena anterior, se presentan como figuras relativamente pequeñas en comparación a las máquinas. A esta escena le precede una toma en plano detalle de una cortadora en plena faena y, así, 
sucesivamente, se muestran otras escenas que glorifican el poder de la recién adoptada maquinaria.

El discurso, como se pudo ver en citas anteriores, continuaba siendo radicalmente antiimperialista y anti-burgués, con un alto contenido plutofóbico; paradójicamente, sin embargo, era similar al de la sacarocracia, en cuanto a su reverencia ante el azúcar y ante la máquina. En 1965, año en que se produce este documental, el país ya se estaba preparando para la gran zafra y esta Quinta Zafra del pueblo — al igual que muchas otras - dependía de las movilizaciones en masas y, en cierta medida, de la incorporación de la nueva maquinaria. El documental, además de legitimar al nuevo poder a través de la reescritura histórica, básicamente cumplía con dos propósitos: exhortar a miles de personas a participar voluntariamente en el sector agrícola de la zafra — corte y alza de la caña- y convencer a los viejos zafreros acerca de la importancia de la mecanización y el trabajo en brigadas.

Para lograr el primer propósito, a la retórica triunfalista le acompañan imágenes positivas, alegres, acordes al nuevo capítulo de la Historia cubana. Mientras el narrador clamaba la importancia de este período, en la pantalla aparecía un grupo de hombres tocando una especie de conga improvisada, al compás de tumbadoras, guitarras y otros instrumentos musicales. La mayoría, sonriente, cantaba, mientras que uno de los hombres bailaba alegremente. Esta misma conga servirá de música de fondo para la próxima escena, donde se muestran a varios trabajadores cortando y alzando caña en el medio de un cañaveral.

Al analizar ambas escenas, lo primero que sorprende es la heterogeneidad racial del grupo de hombres que participan de la conga, si se tiene en cuenta la larga tradición 
marcadamente racista - $\mathrm{y}$ de segregación — existente dentro de la sociedad cubana $\mathrm{y}$, especialmente, en el mundo azucarero. Aunque predomina una mayoría afrodescendiente también hay personas de descendencia blanca y todos, en conjunto, forman una masa festiva, unificada por la música, el canto y el baile. Aquellos espacios racializados construidos durante la colonia, y perpetuados aún después de abolida la esclavitud, se borran y aunque en el documental no se planteé explícitamente, esta escena aparece como un guiño de la postura integradora y antirracista que ostentaba el nuevo poder ${ }^{202}$. En cuanto a los zafreros realizando las tareas agrícolas, la música y la algarabía de la banda improvisada le imprime al trabajo un tono de indiscutible alegría, que se aleja, radicalmente, de la melancolía y la frustración predominantes en el discurso anti-azúcar de la era pre-revolucionaria.

Junto a estas escenas también se van a encontrar las entrevistas de algunas personas que están involucradas en la zafra. Algunos aparecen en pantalla explicando que han venido de otros lugares a participar en el corte de la caña, mientras que otros narran su trayectoria en el mundo azucarero desde la era republicana. En general, las intervenciones van a girar en torno a la producción azucarera — la cantidad de caña que se corta o de arrobas de azúcar que se fabrica-y tanto los zafreros voluntarios como los remunerados mencionarán con entusiasmo su participación en la emulación entre brigadas y sindicatos. Por otra parte, los entrevistados también van a expresar su

\footnotetext{
${ }^{202}$ Aunque no es un tema analizado en este estudio es importante tener en cuenta que, a pesar de la aparente postura integradora y antirracista del régimen, la Cuba revolucionaria sigue siendo, en la actualidad, una sociedad racializada. Durante estos primeros años de la Revolución se persiguió y castigó a personas afrodescendientes que estuvieran involucradas o se manifestaran a favor de organizaciones africanistas, como fuera Poder Negro (Black Power). Walterio Carbonell (1920-2008), por ejemplo, quien en su ensayo Cómo surgió la cultura nacional (1961) deconstruyó la versión tradicional de las Guerras de Independencia cubana, al plantear que fueron los negros, y no los blancos, los verdaderos padres de la nación, fue, debido a esta obra, condenado a trabajos forzados en uno de los campos de las UMAP y a un ostracismo intelectual que lo siguió hasta su muerte.
} 
disposición a obrar según los necesite la Revolución: incorporarse al corte de caña, en el caso de los primeros, o abrazar la mecanización y el trabajo en brigadas, en el caso de los segundos.

Cabe destacar que en el documental también aparecen las voces de los inconformes, negados a participar en brigadas porque según ellos ganan más, o a adoptar las nuevas máquinas cortadoras porque están acostumbrados a realizar el trabajo manual. La inclusión de estas voces, breve, pero necesaria, enfatiza la intención formativa de la obra, por ser justamente a estos individuos a quienes está destinado parte del mensaje. A su postura individualista, dirigida a satisfacer ambiciones personales, se le antepone el deseo de sus compañeros de sacrificarse por la Revolución. Por otra parte, los testimonios de la mayoría de los trabajadores, afirmando que gracias al trabajo en brigadas y a la nueva maquinaria se eleva la producción, también están dirigidos a desarmar estas posturas. En todo caso, el hecho de que se haya presentado este tipo de actitud hacia el trabajo no significa que se le de validez. Una posición inconforme a los proyectos de la Revolución, que claramente exigía la incorporación del hombre al trabajo como cumplimiento de su deber - como lo manifestara Ernesto "Che" Guevara en El socialismo y el hombre en Cuba $(1965)^{203}$ — sólo era representada con el objetivo de ser educada, de que abandonara las taras del pasado y comenzara a ofrecer su trabajo al servicio de la nueva sociedad. La inclusión de estas posturas más bien era un recordatorio de un trabajo ideológico aún por concluir, con el que se continuaría adoctrinando a las masas.

\footnotetext{
${ }^{203}$ Texto que tuvo una enorme influencia en la ideología y políticas de la Revolución, donde Ernesto "Che" Guevara resume su pensamiento en cuanto a lo que significaba ser un revolucionario.
} 
El claro mensaje de la obra, a pesar de estas inclusiones, se puede percibir desde sus dos primeras escenas. El documental abre con la toma en primer plano de un grupo de cañas que están siendo movidas por una figura que no se logra definir, justamente por estar ubicada detrás de éstas. Antes de que el espectador pueda reconocer que se trata de un machetero, el sonido del machete al cortar la caña ya habrá ayudado a descifrarlo. La cámara fija captará el movimiento repetitivo, casi autómata del hombre enfrascado en la faena, hasta que llega un punto en que ya no hay cañas que se anteponen entre el machetero y el espectador. Luego, según se va moviendo al hombre hacia la derecha girará con él, para volver a captar una toma fija muy similar a la anterior: las cañas en primer plano que van desapareciendo de la vista según van siendo cortadas. En la segunda toma, a través de un plano panorámico en picado que permite percibir la dimensión del lugar, el machetero continuará moviéndose libremente por unos segundos hasta que apenas quedan cañas por cortar. Más allá del hombre incansable concentrado en la labor, lo que reluce a la vista en esta toma es la enorme cantidad de caña que ha sido cortada y yace en el suelo.

La próxima escena corresponderá a una entrevista que se le realiza a Reynaldo Castro Yedra ${ }^{204}$, el machetero de la escena anterior, quien aparecerá en primer plano frente a una ventana de lo que pudiera ser su bohío - respondiendo las preguntas que le hará un entrevistador, fuera de campo, de quien sólo se escucha su voz en off. A través de las preguntas el espectador conocerá que Reynaldo ha sido nombrado héroe nacional del trabajo y que su brigada se encuentra a la cabeza en la emulación. También se sabrán

\footnotetext{
${ }^{204}$ Reynaldo Castro Yedra fue nombrado el primer Héroe Nacional del Trabajo por su capacidad como machetero.
} 
algunos detalles acerca del régimen de trabajo diario de la brigada — horas de trabajo, promedio de caña cortada, entre otros-y los nombres de algunos de sus integrantes, a petición del entrevistador. Para finalizar, éste le preguntará a Reynaldo qué sintió al haber sido designado héroe nacional del trabajo, a lo que el machetero le contesta que sintió un gran orgullo y satisfacción por haber sido el primero y que él espera que en un futuro cercano otros también sean elegidos héroes del trabajo al igual que él (00:03:01-35).

Después de estas dos escenas, centradas en la realidad azucarera del presente, el documental comenzará su giro histórico con una entrevista a Fernando Ortiz y con la utilización de imágenes de archivo que servirán para ubicar al espectador en la etapa que describe. Además de estas imágenes, el relato estará acompañado por la voz en off de un narrador que referirá los hechos de la historia según la interpretación oficial. Escenas del presente interrumpirán este relato con el fin de reforzar el discurso de la separación. Las entrevistas a trabajadores azucareros —incluidos descendientes directos de esclavos- o imágenes que muestran a los zafreros enfrascados en sus tareas cumplirán con una especie de función dialógica con la que se demoniza el período anterior. Dentro de estas vueltas al presente, aparecerá Fidel Castro en un campo de cañas recién sembrado hablando sobre la necesidad de practicar el cultivo intensivo de la gramínea con el fin de obtener más azúcar de una misma extensión de tierra. Más adelante se mostrará en otra escena cortando caña junto a Celia Sánchez y otros integrantes del gobierno.

Antes de finalizar el documental, se regresará a la escena de la entrevista de Reynaldo, quien afirma que la introducción de las combinadas y las alzadoras ha sido un gran éxito, ya que la caña es el trabajo más brutal que tiene el campo y así, según se pueda ir eliminando a los hombres en estas faenas, se pueden ir utilizando en otros 
trabajos manuales más simples (00:40:49-12). Luego vendrá la última escena donde aparecerán en primer plano varios macheteros cortando caña mientras se escucha la voz en off del narrador:

Ahora, un hombre importante en Cuba no es el que con mayor habilidad roba los fondos públicos o el que miente con voz melodiosa o el que utiliza su fuerza para burlar al pueblo. Ahora un hombre importante en Cuba, es el que más trabaja y más sirve. Estos son hombres importantes. Reinaldo Castro, Graziliano Rondanes, Juan Sarmiente, José Fernández, Celestino Lemus, Teodoro Melgare, José Fundora, Ramón Torres, los héroes del trabajo, son modestos, eficaces, son útiles y sirven, son hombres importantes de un país nuevo que construye el socialismo. $(00: 41: 17-00)$

Antes de analizar las últimas escenas me gustaría retomar las dos primeras con las que se abre el documental y se introduce la figura de Reynaldo. Desde el punto de vista cinematográfico es muy significativo que las cañas, en principio, aparezcan en primer plano y cubran la figura del hombre, quien poco a poco se irá abriendo paso con su machete. La imposibilidad de distinguir por unos segundos al machetero, hasta que finalmente aparece su rostro en pantalla, para luego volver a ocultarse detrás de otras cañas, trasmite una sensación de agobio, de confinamiento, como si la gramínea, por unos instantes, se lo tragara. En la segunda toma, sin embargo, gracias al plano panorámico en picado que descubre la dimensión del terreno, el hombre ganará el protagonismo. La enorme cantidad de caña que ha ido cortando y yace en el suelo, se antoja como la imagen final de una batalla, donde un solo hombre ha derrotado a todo un ejercito. Reynaldo, el hombre, gracias a esta escena se convertía en un héroe y entraba en la epopeya nacional.

En la escena que le continua, sin embargo, se va a representar a Reynaldo como individuo. Durante la entrevista, aunque hable de sus hazañas como machetero, el 
espectador se encontrará a un hombre común, tímido ante la cámara, de quien sorprende su modestia. A pesar de su escasa educación —que se trasluce en el uso del lenguaje—se puede percibir que ya ha ido integrando a su habla vocablos de la Revolución. Máximo rendimiento, emulación, orgullo y satisfacción ante al trabajo y héroe nacional, entre otras, son palabras y frases que se repiten durante la entrevista y que convierten a Reynaldo, junto a su dedicación al trabajo, en el prototipo del hombre nuevo guevariano.

Aunque en la primera escena se presente como héroe, el hecho de que en esta segunda se descubra al individuo — al hombre común — hace que sus hazañas, aunque de cierta manera grandiosas, se perciban como alcanzables y conviden a la imitación. El propio Reynaldo lo expresa cuando expone sus deseos de que en un futuro otros macheteros como él sean nombrados héroes nacionales de trabajo. Por otra parte, a través de las preguntas del entrevistador, Reynaldo se convierte en una especie de mensajero de la política económica que el gobierno ha adoptado en torno al azúcar, al promover las brigadas de macheteros y la mecanización de la industria.

Esta doble representación, donde el héroe y el hombre se funden, para convertirse en un héroe alcanzable, imitable, vocero de la Revolución, es una de las piezas fundamentales de la obra y le dan a Reynaldo, en tanto a héroe colectivo, un protagonismo indiscutible. La insistencia del entrevistador en que el machetero millonario nombre el resto de los hombres que conforman la brigada — algo que también se cumple al final del documental cuando el narrador menciona varios de estos nombres, expresando que estos zafreros, los que más trabajan y más sirven, son los hombres importantes-, evidencia que esta obra también funciona como una especie de homenaje o estímulo moral para aquellos que se sacrifican por la construcción de la nueva sociedad. 
Teniendo en perspectiva todos estos propósitos que cumple el documental, se puede llegar a la conclusión de que a partir de la revisión histórica que propone y de la representación del héroe azucarero, la incorporación del hombre a la zafra era como una especie de incorporación a una batalla. Si finalmente con la Revolución había llegado un gobierno con el que se identificaban las masas, ahora le tocaba al pueblo revolucionario cumplir con su papel: ofrecer su trabajo para lograr construir la nueva sociedad, algo que ya en 1965, a cinco años de la gran zafra, se traducía en una adhesión a un discurso proindustrial a favor del azúcar, que, paradójicamente, era similar al de la sacarocracia.

Es importante señalar, no obstante, que no todas las obras en torno al azúcar que se realizaron durante estos años se adscribieron a la retórica triunfalista y al tono propagandístico y didáctico que minó gran parte de la producción cultural de la época. Si bien es cierto que otros documentales también sirvieron como herramientas para propagar la ideología y las políticas económicas del régimen y para insertar al obrero azucarero dentro de la epopeya nacional (Héroes del trabajo, Hombres del cañaveral, Monte adentro, Abril de Girón, entre otros $\left.{ }^{205}\right)$, también hay que reconocer que algunos artistas ofrecieron en sus obras aristas diferentes. Dentro del mundo cinematográfico, Sara Gómez se deslinda del discurso del poder al brindar una mirada etnográfica en su documental De bateyes (1971). Ante la inminencia de una gran zafra, Gómez, lejos de producir un documental donde se convoque a las masas a la incorporación a las tareas azucareras, se enfoca en la reconstrucción de la historia de los bateyes, concentrándose, mayormente, en el aporte cultural que ofrecieron los inmigrantes azucareros. A través de

${ }^{205}$ Héroes del trabajo (1962), de Sergio Giral; Hombres del cañaveral (1965), de Manuel Mora; Monte adentro (1965) de José Antonio Jorge y Abril de Girón (1966) de José del Campo, son sólo algunos de los documentales producidos en esta década que giran en torno al azúcar. La lista es mucho más extensa, lo cual evidencia la importancia que la agroindustria azucarera ha tenido dentro de la Revolución. 
los testimonios de inmigrantes caribeños y asiáticos de los centrales Jesús Menéndez y Antonio Guiteras (antiguos Chaparras y Delicias), la obra explora el mundo azucarero como elemento esencial del sincretismo cultural de la nación.

Dentro del campo de la literatura, en 1970 se publica Sacchario, novela de Miguel Cossío Woodward, que como bien apunta Duanel Díaz Infante, a pesar de situarse en la V Zafra del pueblo (1965), "es un reflejo literario de la campaña gubernamental en torno a la Zafra de los Diez Millones" (párr. 28). Esta obra, sería el equivalente narrativo de la producción cinematográfica pro-azucarera comentada en párrafos anteriores, donde se presentaba una marcada escisión entre un pasado pre-revolucionario y la era de la Revolución. Las calamidades que infligía el monstruo azucarero (miseria, tiempo muerto, injerencia norteamericana) y, en general, la era republicana (vicio, crimen, abuso, tiranía), desaparecían a partir de 1959. Su protagonista, Darío, quien durante la República fuera un joven condenado a la marginalidad social, encontraba en la Revolución la esperanza de una vida justa, un evento redentor que no sólo lo salvaría de la eterna pobreza, sino que le daría la oportunidad de insertarse a la epopeya nacional: "saltar de la oscuridad de la triste cuartería hacia la gloria luminosa de los héroes" (144), según sus propias palabras. Ante el convencimiento de su indispensable papel en la construcción de la nueva sociedad,

decid[e] empezar de nuevo ... rechazar la conveniencia de seguir aquella vida tan parecida a la de los burgueses que creía combatir, [] entregar su cómodo y pacífico empleo, para volver la vista únicamente hacia el mañana, hacia lo que implicara esfuerzo, tesón, dedicación, hacia lo que diera sentido a su existencia . . . Decid[e] probarse, foguearse, endurecerse, aprender desde el principio la lección de los héroes y no conformarse nunca más hasta completarla. (246-247)

Este cambio de vida, se traduce, justamente, a la incorporación voluntaria de Darío al 
corte de caña. Sacchario, como acertadamente afirma Ana Serra en su estudio ${ }^{206}$, se adhiere a la retórica del discurso oficial que homologaba a Cuba, a la Revolución y a la integración a las labores azucareras, como si fueran lo mismo (88).

Contrarrestando este discurso enfocado en insertar el trabajador azucarero dentro de la epopeya nacional, se puede tomar de ejemplo el relato de Cos Cause titulado "El viejo", que fuera publicado en el número de Casa de las Américas dedicado a la zafra de los Diez Millones ${ }^{207}$. A pesar de que hay una alusión al cambio que ha traído la Revolución —el personaje empieza su narración afirmando que "[e]stos son otros tiempos ... [y que] todo está virado al revés" (184)— el relato se enfoca en las memorias del viejo.

Cuenta mi padre, que cuando la esclavitud un negro se escapó y estuvo más de tres meses escondido en el alma del monte. Por fin lo encontraron. ... Se lo llevaron al amo y éste mandó a darle un zunda (sic.) tremenda de latigazos. Y fueron tantos y tan fuertes, que el negro hasta se soltó. Y salió llorando y gritando y dejando el pellejo en el camino. Y se murió llorando y gritando.

Su muerte [continua el viejo] trajo problemas peligrosos. A las doce de la noche pasaba su fantasma por el batey, llorando y gritando. Eso no tenía nombre. Los perros se tragaban los ladridos, las mujeres parían antes de tiempo y los hombres temblaban de miedo" (184).

La perspectiva de este breve relato de Cause es muy parecida al enfoque etnográfico del documental de Gómez, en el sentido de que se centra en aspectos culturales de la comunidad azucarera. Rememorar anécdotas que recogían creencias populares, era un ejercicio que se desentendía del discurso del poder, orientado, durante aquel año, a la incorporación masiva a las zafras para lograr los diez millones de azúcar.

También alejado de la retórica del poder se encuentra el relato "De nuevo la

\footnotetext{
${ }^{206}$ The “new Man” in Cuba (2007).

${ }^{207}$ Referencia a la edición número 62 de septiembre-octubre.
} 
ponzoña”, de Antonio Benítez Rojo, publicado en la mencionada edición de Casa. Esta obra, como bien afirma Díaz Infante, destaca de la mayoría de los escritos que aparecieron en la revista debido a su ambigüedad (párr. 23). A pesar de que muchos de los textos que componen este número mencionan el enorme esfuerzo físico que requiere el corte de caña, en casi todos predomina una postura titánica donde el hombre —héroe azucarero- termina saliendo victorioso de la batalla. En el relato de Benítez Rojo, sin embargo, el protagonista muere por la picada de un alacrán escondido en el porrón de agua de los macheteros. Supuestamente, el fatal accidente es causado por la propia mano del hombre, quien "agarra el porrón y lo descorcha porque no sabe beber el chorrito del pico, no sabe beber como los campesinos, los pescadores, los albañiles, [ni] los bailadores que desfilan coreando los cornetazos de Florecita" (127).

Díaz Infante, en su análisis sobre esta obra, entiende que esta muerte se puede "leer como la muerte simbólica de los intelectuales en particular, y de los burgueses en general" (párr. 25), por ser el protagonista de extracción burguesa. Esta visión esta ligada al pecado original que, según Ernesto "Che" Guevara, sufrían los hombres nacidos en la época republicana ${ }^{208}$. Para Díaz Infante, la muerte significaba que la integración del intelectual al corte de caña no era suficiente, que tendría que morir para que se hiciera justicia a todos los inocentes que a lo largo de la historia del país se había tragado el campo de caña (párr. 25). Una segunda interpretación que propone este crítico es la persistencia de la fatalidad en torno al azúcar durante la época revolucionaria. La Revolución, lejos de superar este fatalismo lo reproducía, por lo que la muerte del protagonista se pudiera interpretar como una alegoría del final de la ilusión

\footnotetext{
${ }^{208}$ Sobre esta idea de Guevara ahondaré en el próximo acápite.
} 
revolucionaria sobre el hombre nuevo (párr. 27).

Aunque ambas interpretaciones me parecen oportunas, me decanto por una lectura más aproximada a la segunda. El hecho de que en la narración haya cierta circularidad, dada a través de la repetición de algunas frases, propone la noción de una continuidad de la historia. Por otra parte, los dos eventos que se narran —la rememoración de una noche de carnaval por parte del protagonista, mientras se encuentra cortando caña en una cañaveral - se presentan suprimiendo los planos temporales, lo cual también enfatiza la idea de la continuidad. A ello también se le debe añadir la locución adverbial "de nuevo" que aparece en el título de la obra y que indica una repetición; además del epígrafe que lo acompaña: "A la memoria de los caídos en la guerra del azúcar" (126), que bien se puede leer como un epitafio. El intelectual, lejos de morir para redimir a los inocentes que han sido tragados por el cañaveral, se convierte en otra de las víctimas de la guerra del azúcar. El fatalismo azucarero, como bien apunta Díaz Infante, persiste con la Revolución.

Esta obra de Benítez Rojo, al igual que el documental de Gómez o el breve relato de Cause, se aleja del discurso totalizador de la plantación propuesto por el régimen. A diferencia de los documentales de Titón y Saderman o de la novela de Cossío Woodward, las obras de estos artistas no alaban las bonanzas de la Revolución —enfatizando en el pasado oscuro del azúcar - ni sirven como herramienta propagadora de la ideología y las políticas económicas del nuevo poder, sino que dirigen su mirada a temas diferentes. En el caso del cuento de Benítez Rojo, se pudiera tomar como precursor de las obras que Reinaldo Arenas escribe acerca de la historia del azúcar dentro de la Revolución. 


\subsection{EL CENTRAL Y ARTURO LA ESTRELLA MÁS BRILLANTE: LA CONTRA-}

\section{MEMORIA AZUCARERA EN LA OBRA DE REINALDO ARENAS}

En el año 2016, en conmemoración de su vigésimo aniversario, la compañía teatral Argos Teatro estrenaría una obra titulada 10 millones. Se trataba de una pieza autobiográfica escrita y dirigida por Carlos Celdrán, su fundador, donde se narraba fundamentalmente la vida de Carlos (ahora personaje) desde su niñez, a mediados y finales de la década del sesenta, hasta su primera juventud, en los años ochenta.

En medio de la efervescencia revolucionaria que conmovía al país, donde se trataba de moldear al masculino hombre nuevo, Carlos era una niño amanerado, sensible, tímido, a quien su madre forzaba a que adoptara la actitud de un hombre varonil, fuerte, violento, como correspondía a un buen revolucionario. Por otra parte, la madre también mediaba y limitaba la relación del hijo con su padre, tildado no sólo de apático burgués sino además de disidente político, por no participar en el proceso revolucionario, mantener relaciones con familiares exiliados en los Estados Unidos y, posteriormente, ser él mismo quien abandonara el país.

La historia, aunque personal, representa una época donde la ideología del régimen afectó profundamente la psicología de toda una nación en su afán de homogenizar el pensamiento de la colectividad, que se concebía revolucionaria y heteronormativa — dos sinónimos convertidos en homólogos durante este período, según el discurso oficial一. Se trataba de una historia de trauma, un trauma colectivo que había sido infligido a los individuos al forzarlos a abandonar sus singularidades en aras de un bien común; pero también se trataba de un ejercicio memorístico y anti-hegemónico, que a partir de la memoria individual de la historia reciente apelaba a la memoria oscura, silenciada, de la 
comunidad. Era, de cierta manera, lo que Michel Foucault definió como contra-memoria: la reescritura de la historia a partir de un proceso discursivo de resistencia, al cual se le insertan memorias que han sido previamente excluidas del discurso oficial.

A pesar de ser su madre la directora de un Complejo Agroindustrial (CAI)nombre con el que fueron bautizados los centrales azucareros después del triunfo de la Revolución - y de que Carlos (personaje) narre sus vivencias acerca de la quema de un cañaveral — experiencia que vivió, justamente, por entender su madre que aquel grupo de hombres fuertes y entregados al brutal trabajo azucarero era el contexto idóneo para formar un niño-, la obra no se centra en la gran zafra de 1970, por lo que su título (10 millones) adquiere gran simbolismo.

Sin conocer las verdaderas intenciones que movieron a Celdrán para escoger este nombre, no es difícil de asumir que este hecho histórico —uno de los más significativos que vivió la nación cubana en la era revolucionaria - se puede interpretar como una especie de alegoría de lo que significaron aquellas primeras décadas de la Revolución. Para muchos, dentro de la euforia de los primeros años, se trataba de la oportunidad de ver, finalmente, cumplidos sus sueños en la promesa de la sociedad que estaban construyendo. Para otros, los que nunca creyeron o se desengañaron desde un principio, era la asfixia que producía aquel espacio cerrado, intolerante, incapaz de aceptar un pensamiento o comportamiento fuera de las normas de la Revolución o, incluso, una crítica. Los primeros, que se habían volcado esperanzados en la construcción de la utopía, llegaron al clímax en aquella épica zafra de 1970, donde producir diez millones de toneladas de azúcar se había convertido en la nueva gran batalla que tenían que librar. Para los segundos, sin embargo, también se trató de un momento memorable, pero en este 
caso, de una vivencia impuesta que terminó siendo una experiencia infernal. La alusión a diez millones en esta obra — debido al gran impacto que había infligido esta zafra en la sociedad - dejaba de ser una cifra, una zafra, un año específico, para convertirse en el símbolo de la historia revolucionaria, de la Revolución en sí, que resultó siendo, para todos, traumática.

Es justamente la voz de estos segundos, la de los que sintieron desde casi al inicio que el colectivismo promovido por la oficialidad era asfixiante, la de los que fueron obligados a participar en el proceso revolucionario — que en muchas ocasiones se tradujo al trabajo forzado en un campo de cañas - y la que fue, sobre todo, violentamente silenciada, la que recoge Reinaldo Arenas en su poema El central (1981) y en su relato Arturo, la estrella más brillante (1984), ambos escritos en Cuba, pero publicados posteriormente en el exilio.

En el poema, escrito a partir de su propia experiencia en un central durante la Zafra de los diez millones en 1970, donde fuera enviado a cortar caña y a escribir un libro laudatorio — según sus propias palabras ${ }^{209}$ —, Arenas se aproxima y reescribe la historia de la esclavitud y el trabajo forzado en Cuba, mayormente en las plantaciones azucareras, haciendo un paralelismo entre la encomienda indígena y el sistema esclavista durante la conquista y la colonia y la ley del Servicio Militar Obligatorio implantada por la supuestamente liberadora Revolución. A través de una escritura cargada con signos de la postmodernidad $^{210}$, tanto a nivel semántico como sintáctico, se va a deconstruir la versión

\footnotetext{
${ }^{209}$ En su autobiografía, Antes que anochezca (1992), Arenas explica como en 1970 los oficiales de la Seguridad del Estado lo enviaron a cortar caña y a escribir un libro laudatorio sobre la Zafra de los Diez Millones en el Central Manuel Sanguily — antiguo Niágara - en la provincia de Pinar del Río (154).

${ }^{210}$ En este trabajo me concentraré fundamentalmente en el uso de la fragmentación cronológica, la
} 
oficial de esta épica zafra y, en general, el discurso totalizador de la plantación adoptado por el gobierno revolucionario. Como resultado, el texto funciona como una especie de contra-memoria que desafía el discurso de la separación dentro de la reescritura conquistadora del régimen. Se trata de una nueva reinterpretación histórica, pero esta vez, a partir de un proceso discursivo de resistencia contra el nuevo poder.

Aunque varios trabajos académicos ya han tratado los aspectos postmodernos de la narrativa de Arenas como un espacio de resistencia (Béjar 1987, Bertot 1994, Zéndegui 2003, Ocasio 2007) y otros, incluso, han enmarcado este poema dentro de los textos cubanos relacionados al azúcar (Barreda 1984, Benítez Rojo 2010, Matušková 2014), al incluirla en este estudio se va a recontextualizar en un marco mucho más amplio, que abarca gran parte de la historia azucarera cubana. A través de esta inclusión, la obra dialogará con el resto de los textos analizados en este trabajo, lo cual permitirá destacar su significancia dentro del heterogéneo corpus cultural en torno al azúcar que en este estudio reúno, específicamente dentro de su vertiente anti-azúcar —el discurso de resistencia a la plantación. Si la retórica del gobierno insistía en deslindarse de las prácticas del viejo poder — sistema esclavista o pésimas condiciones para los trabajadores azucareros durante la república, crisis económicas, dependencia del mercado norteamericano y su subsecuente injerencia en los asuntos de la nación, entre otros- la obra de Arenas emerge para desmitificar esta discurso de la separación y demostrar que el discurso totalizador de la plantación, con todas sus negativas consecuencias, continuaba siendo, dentro de la Revolución, el discurso dominante.

intertextualidad, la parodia, el erotismo y la autoreferencialidad, entre otros, como recursos que se utilizan para socavar la veracidad de los textos históricos y, en especial, la versión histórica azucarera del régimen revolucionario. 
El poema, un largo texto donde se combina la prosa y el verso, está dividido en once secciones y en la mayoría de ellas la narración va a romper con la cronología, como bien apunta Matušková, para de esta forma borrar las fronteras históricas (23), creando paralelismos entre el pasado y el presente. En la primera sección, por ejemplo, titulada "Manos esclavas", las manos esclavas habían sido en el pasado tanto las que pulieron el grano de azúcar que la reina se llevaba a la boca, como las que habían cuajado el jugo que más tarde se convertiría en el terrón para el disfrute del extranjero. En el presente, esas mismas manos esclavas, siguiendo las órdenes del gran dictador o rey, serían las que tendrían que trabajar en los campos (11). Después de estas primeras cuatro estrofas donde los tiempos históricos se funden — colonia, república y revolución—, en el poema se seguirán mezclando indistintamente estas etapas históricas para de esta forma crear una sola historia, repetitiva, circular $^{211}$, que sería la historia —en minúscula— de los oprimidos de la plantación.

Otros ejemplos de claro paralelismo se van a encontrar en la segunda y la tercera sección, tituladas "Las buenas conciencias" y "Una cacería tropical”, respectivamente. En la primera, Arenas parodia los textos donde Bartolomé de las Casas denunciaba las barbaridades que los encomenderos cometían con los naturales de las Indias, al mismo tiempo que proponía como remedio la esclavitud africana ${ }^{212}$. Mientras que la voz de Las Casas describe a los negros para convencer a sus Majestades de que son, a diferencia de

\footnotetext{
${ }^{211}$ En entrevista recopilada en La memoria frente al poder (2001) Arenas habla de esta visión de la historia, plasmada en El central, como una especie de horror circular.

${ }^{212}$ Aunque Barreda y Matušková plantean que Arenas parodió en este poema la Brevísima relación de la destrucción de las Indias (1552), no me queda claro que este haya sido el único texto parodiado, teniendo en cuenta que varios de los textos de Las Casas denuncian el etnocidio indígena al mismo tiempo que proponen la esclavitud africana.
} 
los indios, aptos para trabajos duros, el narrador expone los motivos por los cuales son los jóvenes cubanos, y no los hombres ni las mujeres, las personas idóneas para ser reclutadas para el trabajo.

Según Las Casas —en la carta ficticia que Arenas escribiera—,

los etíopes de África son más fuertes, son negros . . y por su fortaleza, por la negrura de su piel y por la rigidez de su pelo poseen condiciones más adecuadas para llevar a cabo los regios planes de sus majestades. Ellos soportarían mejor las violentas labores. Además, son feos. . . . Los naturales de estas islas [por su parte] son dulces y melancólicos y [] prefieren la muerte inmediata a renunciar a sus danzas, a sus fiestas, a sus prodigios desnudos sobre aguas y hojas. (22)

Las razones que esgrimía Las Casas tanto para condenar a los negros a los trabajos forzados como para liberar a los indios eran completamente absurdas e irrisorias. No había un argumento de peso, excepto la supuesta fortaleza corporal de los africanos, que validara su propuesta. Lo irónico, es que los textos originales lascasianos donde se sugería la esclavitud africana también carecían de fundamentos legítimos, a pesar de que fuera una postura compartida con quienes, al igual que él, deseaban evitar la total extinción de los indígenas americanos ${ }^{213}$. Al parodiar estos textos, Arenas pone en tela de juicio, como bien señalan Barreda y Matušková, la validez de la Historia escrita —y en particular de la historiografía cubana-, pero también deconstruye el discurso biológico que devendría más tarde en el racismo científico o biológico del cual Las Casas sería un precursor.

En el caso de los adolecentes cubanos, se van a mencionar un sin fin de motivos por los cuales serían los únicos que van a resistir las duras labores que exigía la

\footnotetext{
${ }^{213}$ Al respecto de este tema puede leer "Bartolomé de las Casas y la esclavitud africana" (1992) de Luis N. Rivera Pagán.
} 
Revolución. Dentro de estas aptitudes, una de las que más resalta y en las que más se insiste, sería la inocencia, una especie de naturaleza pura, no contaminada, que los hacía las víctimas predilectas del poder: "Los adolecentes dondequiera saben estar, pues siempre están más allá. No tienen criterios exclusivos, no tienen alma ni principio: no están corrompidos" (24).

Más adelante, a través de una parodia a la ley del Servicio Militar Obligatorio, promulgada por el gobierno en $1963^{214}$, que dictaba el reclutamiento obligatorio de los jóvenes para que fueran incorporados al trabajo, se añadía que:

Ellos serán los únicos que como habitan en otro mundo pueden soportar cualquiera; y como su orgullo y su indiferencia y su capacidad para la dicha están por encima de nuestros más flamantes aparatos de la persecución y de la ofensa, no pueden ser humillados. Además, como no están envilecidos, es decir, como no son hombres, no abrazaran nuestras doctrinas para adquirir privilegios y dejar de producir". (25)

Esta insistencia en la inocencia de los jóvenes, en comparación a los hombres, es un guiño intertextual implícito que remitirá al El socialismo y el hombre en Cuba (1965), texto donde Ernesto "Che" Guevara había alertado acerca del pecado original: la existencia de las taras del pasado que se trasladaban al presente en la conciencia individual. Los jóvenes, sin embargo, no estaban contaminados y de cierta forma, como señala Arenas sarcásticamente, eran los elegidos (13). Regresando a la metáfora de la pintura donde se representa el descubrimiento de América, se pudiera deducir que los jóvenes eran tenidos por una especie de tabula rasa, de masa fresca y fusiforme con la que el nuevo poder podría moldear el hombre nuevo, mientras les escribía su historia.

\footnotetext{
${ }^{214}$ Aunque puesta en vigor en 1964, la ley No. 1129 - ley del Servicio Militar Obligatorio (SMO) - fue promulgada el 12 de noviembre de 1963. En ella se estipulaba que todos los jóvenes entre 16 y 27 años tenían que pasar el servicio militar por una período de tres años. La mayoría eran incorporados a labores agrícolas, sobre todo a la zafra azucarera y se le pagaba siete pesos cubanos al mes (Ros 264), una cifra irrisoria que constituía la décima parte del salario estatal mínimo para trabajadores del sector agrícola.
} 
Cabe señalar, sin embargo, que dentro del ejercicio paródico que desacredita la veracidad de la Historia y las bondades de la Revolución, también hay una alusión a un erotismo burlesco, desacralizador, que en La Casas se manifiesta con el anuncio de la llegada de la primavera y los deseos del clérigo de "tirar los hábitos y echar a correr [. . . ] de empezar a gritar, a aullar ... de revolcar[s]e entre las hojas lisas y relucientes" (19). La evocación de esta estación del año, donde la naturaleza convidaba a la lujuria, no sólo contrasta con la solemnidad de un texto que es dirigido a las Divinas Majestades, sino que además debilita la credibilidad del fraile cuyos impulsos carnales van en contra de su sagrado voto de castidad. En términos generales, también se puede interpretar como una burla que socava la rigurosidad y la honestidad de las instituciones católicas.

En cuanto a los reclutas, Arenas describía que tenían "una forma insuperable de inaugurar la mañana al ajustarse los calzoncillos verdes. Y [un] ademán señorial con el que se palpa[ban] los testículos", lo cuales constituían "sus únicos tesoros; los necesarios" (24). Aquí hay una referencia y una burla directa a las instituciones militares, en cuanto a espacio masculino y austero, pero también a la noción de que los jóvenes fueran la esperanza de la Revolución. No hay que olvidar que en su autobiografía ${ }^{215}$ Arenas explica que el central azucarero donde fuera a cortar caña en 1970 era una gran unidad militar, llena de jóvenes reclutas que estaban pasando allí el servicio militar obligatorio (154). El color verde que se menciona en esta cita va a remitir al uniforme marcial, a la sobriedad y a la disciplina varonil que exige ese tipo de institución. La prenda interior, sin embargo, al igual que la mención de los testículos como únicos tesoros, por parte de un narrador testigo, abiertamente homosexual, contaminan de lujuria

${ }^{215}$ Antes que anochezca (1992) 
homoerótica un espacio que se entiende como un lugar de rectitud, heteronormativo por excelencia. El verde, por otra parte, también transporta a la esperanza. ¿Eran estos jóvenes, o más bien esta imagen de adolescentes en ropa interior palpando sus genitales, los pilares sobre los que se construiría la nueva sociedad? ¿Eran estos jóvenes convertidos bajo la mirada del intelectual homosexual en objetos del deseo, los nuevos héroes de la patria? La burla, al concentrarse en los genitales, terminaba reduciendo la masculinidad - tenida como una cualidad indispensable de todo revolucionario- a un mero mundo falocéntrico del deseo: poseer los órganos reproductivos masculinos, según el homosexual de Arenas, era todo lo que necesitaban los jóvenes y, al parecer, también era todo lo que les exigía la Revolución.

En "Una cacería tropical" el paralelismo va a estar dado entre la cacería de los negros en África, que posteriormente serían vendidos como esclavos para trabajar en plantaciones azucareras, y las famosas recogidas de jóvenes, muchas veces homosexuales, que realizaba la policía por las calles habaneras, junto a agentes del Departamento de la Seguridad del Estado. Estos jóvenes serían enviados más tarde a centrales o fincas estatales donde se les obligaría a realizar faenas agrícolas. En este caso, Arenas va a parodiar la novela o más bien la biografía novelada de Lino Novás Calvo (1903-1983), titulada Pedro blanco, el negrero (1933) ${ }^{216}$, donde se narra la vida de este personaje real, traficante de negros.

Para lograr el paralelismo, además de la ausencia o mínima puntuación, la narración de ambos eventos se va a yuxtaponer hasta fundirse en una. Gracias a estas

\footnotetext{
${ }^{216}$ La obra en las primeras ediciones apareció bajo el nombre de El negrero: vida novelada de Pedro Blanco Fernández de Trava.
} 
técnicas narrativas la figura del joven se homologará a la del negro, y la del policía o agente de la seguridad a la del negrero. El lector, por su parte, asistirá simultáneamente a la persecución y captura de ambos — negros y jóvenes - tanto por las selvas africanas como por las calles de la ciudad.

Pero el negro matungoz o dahomellado o karabalí o minas o lucumí o ajudas o koromantis o negro no está desprevenido y ante el portentoso despliegue de arcabuces rebenques lazos que se deslizan más hábiles que serpientes y curañas que ya se agitan huye pero he aquí que ya llegan los camiones a los largo de la calle 23 toda una caravana de perseguidores acaba de estacionarse allá una cuadrilla de picas hábilmente manipuladas por viejos piratas avanza acá un centenar de soldados se parapetan tras los muros vigilan escaleras $\mathrm{y}$ edificios cierran las calles por donde diestroshacen su entrada los agentes del Ministerio del Interior se agitan los filibusteros los marineros que sueñan opulentos porvenires se preparan trampas y el negrero ordena soltar los perros. (32)

Más adelante, utilizando las mismas técnicas narrativas, será el barco negrero, que transporta a los esclavos a las costas americanas, el que se homologue a las guaguas que llevan a los jóvenes a una Granja Estatal. Al final de esta parte del poema la narración se interrumpe abruptamente para dirigirse al lector:

¿Oyes sus gritos? Oyes el estruendo que arman esos pobres allá abajo. Tú, que estás en la esquina luego de haber engullido (previa cola) un helado de chocolate. Tú que miraste pasar la interminable fila de las guaguas, un poco fastidiado pues te hicieron perder algunos minutos al cruzar la calle, ¿oyes algo?, ¿Escuchas algún comentario?, ¿Piensas?, ¿Meditas?, ¿Sabes realmente lo que está ocurriendo? ¿Conoces la Historia? Tú, asqueroso lector, ¿eres realmente mi semejante? (35)

Este pasaje es muy significativo porque en el Arenas invita o más bien fuerza al lector a la reflexión acerca de los sucesos que narra, acontecimientos históricos que no han sido recogidos por el discurso oficial del régimen, pero que él se atreve a enmarcar dentro de la historia de la nación, reclamando su espacio. Al mismo tiempo, con este juego autorreferencial Arenas reconoce la condición artificial de su texto, que aunque se 
considere como literatura testimonial, nunca será capaz de representar la realidad en su cabalidad. Esta incapacidad representacional del lenguaje se va a extender a los textos de Las Casas y Novás Calvo que aquí parodia y en general a toda la literatura, incluyendo géneros que generalmente se han asociado a la veracidad y a la objetividad como serían el testimonio, la biografía y los textos históricos.

Además de estas referencias a la literatura como artefacto, también hay en la obra alusiones directas al discurso del nuevo poder. En la primera sección del poema lo describe como

\author{
Rústico y gritón \\ Amenazador y furioso \\ Bárbaro y bambollesco \\ Ha de ser el discurso del nuevo trajinador de sentimientos. $(12)^{217}$
}

Unido a esta retórica triunfalista y cargada de violencia con la que el gobierno se dirigía a las masas, se encontraban las "promesas, descomunales y estúpidas" y las "leyes, intransigentes y arbitrarias", además de las alusiones a la "patria" y a los "sagrados principios" por los cuales las manos esclavas se adentran en la tierra y se desgarran (13). Advertía Arenas con estos versos la doble naturaleza del discurso, persuasivo e intimidatorio, cuyas claras intenciones eran las de incorporar a la población al trabajo agrícola en las plantaciones azucareras, apoyando el proyecto revolucionario que prometía una nueva sociedad. Más adelante también describe otras maneras de como el régimen convoca a las masas: "detrás de todas esas fiestas públicas. Detrás de todo desfile, himnos, despliegue de banderas y elogios. Detrás de toda ceremonia oficial, se

${ }^{217}$ Debido a que en el poema es escrito en verso y prosa la numeración en paréntesis al final de casa cita corresponderá al número de página. 
esconde la intención de estimular tu coeficiente de productividad y de explotarte" (15).

En cuanto a la versión histórica de discurso del poder, también hay una clara alusión a su intento de separarse de algunos eventos del pasado y al efecto que surge en la población. El "nuevo dictador ... sabe tetrificar (énfasis añadido) el pasado y manejar los resortes de la esperanza en esa multitud estupidiza de siempre" (35). Por otra parte, sin embargo, este mismo discurso evocaba la Historia para legitimar los proyectos revolucionarios.

La patria os llama. Hijos amantísimos.

Se invocan los héroes, Se citan los muertos.

Toda la sangre derramada sobre la tierra en cualquier momento de su cansona biografía se te recuerda para que tú des la tuya, oh hijo amantísimo, oh hijo queridísimo, hijo mío. (50)

Con estos versos cargados de ironía se descubría el uso monumental de la Historia por parte del nuevo poder. Por un lado, la versión oficial insistía en la separación, en todo lo que Cuba había sido pero que ya no era, para construir así un espacio propio, dentro de la Historia de la nación, donde se sacralizara la Revolución. Por el otro, sin embargo, se revivían los héroes para infundirle al presente la gloria de las gestas pasadas con lo que, según Arenas, se justificaban los sacrificios que exigía la construcción de la nueva sociedad, incluido el trabajo forzado en las plantaciones azucareras. El central, por su parte, debido a su naturaleza mnemónica y a su discurso anti-hegemónico, se erigía como una memoria o más bien una contra-memoria en contra del poder. De la misma manera que la oficialidad se aferraba al discurso de la separación y al uso monumental de la Historia, a aquel ejercicio selectivo de la memoria donde se borraban o rescataban capítulos históricos nacionales, Arenas va a recoger textos que pertenecen a la 
historiografía cubana para parodiarlos, creando paralelismos con su realidad dentro de la era revolucionaria, descubriendo eventos que se repiten y que socavan el discurso de la separación. Como resultado, ofrece una historia circular donde incluye las voces de quienes habían quedado fuera. Los indios, los negros y ahora los jóvenes reclutas, forzados a trabajar según estipulaba la nueva ley, todas víctimas de la plantación azucarera, entraban, gracias a esta obra, en la historia - y en la memoria - de la nación.

Además de su versión acerca de la Zafra de los 10 millones, evento trascendental que devino símbolo de la euforia, casi esquizofrénica, de aquellas primeras décadas revolucionarias, pero también del autoritarismo del régimen al forzar a las masas a incorporarse a las zafras, incluyendo a jóvenes — casi niños—, Arenas escribe Arturo, la estrella más brillante, un relato donde se cuentan los horrores acontecidos en las Unidades Militares de Ayuda a la Producción (UMAP) ${ }^{218}$.

A diferencia de las unidades militares donde eran enviados los reclutas a pasar el servicio militar obligatorio, por el período de tres años como estipulaba la ley, las UMAP, según el régimen, fueron creadas para jóvenes en edad militar que no estaban integrados al proceso revolucionario y, por lo tanto, no pertenecían a una unidad militar regular. Raúl Castro, tras una visita que realizara a la Unión Soviética, Bulgaria y otros países del Bloque del Este, se percató de que había muchos jóvenes en las calles de la Isla que, según su apariencia, no estaban comprometidos con la Revolución, algo que no había visto durante su visita a los países amigos, porque ya estos habían limpiado sus

\footnotetext{
${ }^{218}$ Para más información acerca de las UMAP puede remitirse a los trabajos investigativos de Enrique Ros, La UMAP: el gulag castrista (2004); Joseph Tahbaz, "Desmistifying las UMAP: The Politics of Sugar, Gender, and Religion in 1960s Cuba" (2013); Abel Sierra Madero, "Academias para producir machos en Cuba” (2016) y también a la obra de Félix Luis Viera, Un ciervo herido (2002), entre otros.
} 
calles de las lacras sociales $(\operatorname{Ros} 13)^{219}$.

A raíz de este acontecimiento Fidel Castro propone la creación de las UMAP, centros donde los jóvenes desafectos serían reeducados ideológicamente. La misión, según el líder, era que "cambi[aran] de actitud, educándose, formándose, salvándose” (cit. en Ros 14). Los verdaderos propósitos, sin embargo, incluían la reubicación de varios miembros del Ejercito Rebelde (ahora las $\mathrm{FAR}^{220}$ ) que habían adquirido méritos militares en la Sierra Maestra, pero que eran semianalfabetos y no tenían cabida dentro de las fuerzas armadas profesionales. En cuanto a los jóvenes, más allá del intento de reeducación ideológica, lo que se pretendía era suplir — como en su momento lo habían hecho los esclavos africanos - la escasez de mano de obra para las labores agrícolas en la región de Camagüey, en especial en las plantaciones azucareras (Ros 46-47). Los unos se convertirían en carceleros de los campos de trabajo forzado, mientras que los otros serían sus confinados.

Aunque muchos de los destinados a las UMAP fueran religiosos u homosexuales hombres — justamente la obra de Arenas trata sobre éstos últimos- es importante destacar que estos campos no sólo estaban constituidos por personas pertenecientes a alguna de estas categorías. Según el trabajo investigativo de Joseph Tahbaz, además de los miembros de diferentes credos religiosos — católicos, Testigos de Jehová, santeros, metodistas, abakúas, entre otros - y los homosexuales, a las UMAP fueron condenados intelectuales, artistas, hippies, drogadictos, prisioneros políticos, campesinos que se

\footnotetext{
${ }^{219}$ Enrique Ros cita la entrevista del escritor cubano Heberto Padilla en el documental Conducta impropia (1984) de Néstor Almendros y Orlando Jiménez Leal.

${ }^{220}$ Desde 1959 el Ejército Rebelde pasó a llamarse las Fuerzas Armadas Revolucionarias (FAR).
} 
oponían a la colectivización, proxenetas, prostitutos, lesbianas ${ }^{221}$, estudiantes universitarios ideológicamente inconformes, oficiales del gobierno acusados de corrupción, criminales, personas que se sospechaba tenían intenciones de abandonar el país $\mathrm{y}$, en general, todo sujeto que el régimen considerara antisocial o contrarrevolucionario (párr. 3). Esto no significaba, sin embargo, que se tratara de personas que se hubieran declarado en contra de la Revolución, muy por el contrario, era el régimen militarista y autoritario, con su afán de homogenizar la sociedad, el que entendía que este tipo de individuos o comportamientos no eran de verdaderos revolucionarios. En este sentido, se pudiera hablar del desmembramiento de la nación, pensando en todos los sujetos que fueron expulsados del imaginario nacional revolucionario, que para algunos también significó el confinamiento, durante un período de tiempo, en las UMAP.

En cuanto al trabajo, los reclusos eran destinados a diferentes tareas agrícolas, como la recogida de boniatos, yucas, el corte de marabú, la aplicación de fertilizantes, entre otros, pero mayormente a la siembra y a la cosecha de la caña de azúcar ((Ros 131132, Tahbaz, párr. 8). Las jornadas de trabajo, aunque variaban según los diversos testimonios, generalmente eran de diez y hasta doce horas diarias de lunes a sábado. Durante el tiempo de la zafra, que podía durar hasta seis meses ${ }^{222}$, el trabajo se intensificaba y prácticamente los reclusos trabajaban en el corte de caña desde el

\footnotetext{
${ }^{221}$ Aunque muchos de los testimonios de personas que estuvieron en las UMAP niegan haber visto mujeres en estos campos, Lillian Guerra (Visions of Power [2012]) afirma que a ellos también fueron condenadas lesbianas y prostitutas. Existe la posibilidad de que sólo a algunos campos fueran destinadas las mujeres, de ahí que muchos reclusos no supieran de su existencia.

${ }^{222}$ Aunque típicamente las zafras se realizaban entre los meses de enero a abril, durante esta época, debido a la falta de brazos, se comenzaban en noviembre y podían durar hasta junio.
} 
amanecer hasta el atardecer (Tahbaz, párr. 9). Este trabajo, al igual que a los reclutas, era remunerado por siete pesos al mes, un cifra muy por debajo del salario estatal mínimo 223 y prácticamente simbólica. No obstante, hay que tener en cuenta que durante este período el trabajo no retribuido no era una excepción. Lo más abusivo y condenable, más allá de que se tratara de trabajo forzado — a diferencia del trabajo voluntario que ofrecían otros integrantes de la sociedad-, serían la excesiva cantidad de horas de trabajo y las pésimas condiciones en que lo hacían.

Para tener un mejor entendimiento de cómo las UMAP entran dentro del discurso azucarero de la plantación, es necesario retomar la política del gobierno en torno al azúcar a partir del año 1965. En el apartado anterior se explicó como después de una fallida postura económica anti-azúcar, el régimen decidió volcarse en la agroindustria azucarera como única vía que podría librar a la Isla del subdesarrollo. El Plan Perspectivo Azucarero, a diferencia de la política de desmantelamiento, estipulaba el incremento de caballerías de tierra destinadas al cultivo del azúcar y la siembra de variedades de caña más rentables, además de la introducción de maquinaria que facilitara la producción, sobre todo en el sector agrícola. La ganancia obtenida por la venta del azúcar a la Unión Soviética durante estos años serviría no sólo para pagar la deuda que se había adquirido con este país, sino también para invertir en la industrialización de la Isla (Pérez-López 12-13, Tahbaz, párr. 22). El único problema era que muchos de los macheteros experimentados, a raíz de las oportunidades que les había ofrecido la Revolución, ya no querían incorporarse al brutal trabajo del corte de caña ${ }^{224}$. El llamado a las masas para

\footnotetext{
${ }^{223}$ Ver nota 214.

${ }^{224}$ Para más información sobre las causas de la escasez de mano de obra en el sector agrícola puede
} 
que participaran, de manera voluntaria, a las ahora zafras del pueblo, más que un capricho se había convertido en una necesidad. La creación de las UMAP, era sólo una extensión del Servicio Militar Obligatorio, en el sentido de que fueron concebidas teniendo en perspectiva esta escasez de brazos dentro de las plantaciones azucareras.

En cuanto a la obra de Arenas, además de la incorporación de los reclusos al trabajo también hay que tener en cuenta la política sanitaria que proponía el régimen con relación a la homosexualidad. Diferentes estudios han señalado que durante las primeras décadas de la Revolución el nuevo gobierno entendía la homosexualidad como una enfermedad contagiosa que podía prevenirse e incluso curarse (Leiner 1994, Marqués ${ }^{225}$ ). Justamente siguiendo este criterio, para evitar el temido contagio, algunos campos de las UMAP fueron destinados exclusivamente para hombres homosexuales, una política muy similar a la que mantuviera el sistema colonial, en cuanto a las categorías del espacio social y a la negación de la heterogeneidad, conceptos propuestos por Goldberg, analizados previamente en este estudio.

En acápites anteriores se examinaron textos que datan de la era colonial donde la concepción de nación, a pesar de su existencia y su importancia en la economía de la sociedad, negaba la presencia negra en la Isla. También se pusieron ejemplos de cómo se construían los espacios sociales en dependencia de las categorías raciales. En el caso de la nación revolucionaria, aquella masa homogénea imaginada por el régimen, serían los homosexuales - y el resto de los confinados a los campos de trabajo forzado- a quienes

consultar las obras de "Desmystifying las UMAP" (2013), de Joseph Tahbaz, y The Economics of Cuban Sugar (1991), de Jorge López-Pérez, ambas citadas en este acápite.

${ }^{225}$ Este estudio de Marqués, publicado en la revista digital de literatura La Habana Elegante, no tiene fecha. 
se les negaba el derecho a la comunidad, relegándose a un espacio marginal o heterotopía $^{226}$ —en palabras de Foucault - necesario para que fuera posible la utopía revolucionaria. Es acerca de las experiencias de un amigo en este espacio, que de 1965 a 1968 se tradujo a los campos de las UMAP, que Arenas se inspiró para escribir su relato Arturo, la estrella más brillante.

Aunque nunca estuvo en un campo de las UMAP, en el apartado de su autobiografía titulado Nelson Rodríguez Leyva (1943-1972) ${ }^{227}$, Arenas explica que tanto Arturo como un poema que luego escribió en el exilio ${ }^{228}$ fueron dedicados a este escritor cubano, homosexual, que fuera condenado a uno de estos campamentos en 1965 (175). Después de tres años realizando trabajo forzado como recluso, Nelson logró que lo dejaran salir por enfermedad mental ${ }^{229}$. La experiencia en este lugar fue tan horrorosa que en 1971, temiendo que fuera a ser víctima, una vez más, de persecuciones por parte del régimen, decidió con un par de amigos secuestrar un avión para desviarlo hacia Miami. El intento fue fallido y tanto Nelson como el amigo que lo acompañaba, Ángel López Rabí, fueron posteriormente fusilados ${ }^{230}$. En una nota que aparece al final de su relato Arenas narra este episodio:

\footnotetext{
${ }^{226}$ En "Des espaces autres" (1967), traducida al inglés como Of Other Spaces.

${ }^{227}$ Nelson Rodríguez Leyva fue un escritor de poesía y narraciones breves. En 1964 fue publicado por la editorial estatal Ediciones R su colección de cuentos titulada El regalo. Este, que fuera su primer y único libro, también fue recientemente publicado por la editorial Betania en el año 2015.

${ }^{228}$ Referencia al poema "Si te llamaras Nelson (A un joven norteamericano)" escrito en Nueva York en 1981 y publicado en su poemario Voluntad de vivir manifestándose (1989).

${ }^{229}$ Algunos estudios sobre las UMAP estiman que alrededor de quinientos confinados terminaron internados en pabellones psiquiátricos (Tahbaz párr. 3).

${ }^{230}$ Para más información sobre estos sucesos puede consultar el prólogo, escrito por Rafael E. Saumell, de la reedición del libro de Nelson que realizara la casa editorial Betania en el año 2015.
} 
Desesperado, en 1971, intentó, provisto de una granada de mano, desviar de su ruta un avión de Cubana de Aviación, rumbo a la Florida. Reducido y en trance de ser asesinado por las escoltas militares del avión, Nelson tiró la granada que hizo explosión. El aparato aterrizó en el aeropuerto José Martí en La Habana. Nelson Rodríguez y su amigo y acompañante, el poeta Ángel López Rabí — de 16 años de edad- fueron fusilados. (“Arturo" 81-82)

Arenas también explica que Nelson había escrito un libro de relatos sobre sus experiencias en las UMAP: "era un libro extraordinario constituido por innumerables viñetas donde narraba cosas ocurridas en el campo de concentración donde había estado" (“Antes” 173). El paradero de este manuscrito es aún desconocido, pero pudo, según Arenas, haber sido confiscado por las autoridades cubanas ("Arturo" 82). Tanto las experiencias de Nelson en las UMAP como su horrendo fusilamiento marcaron profundamente al escritor exiliado. Un par de años antes de suicidarse, en 1990, le propuso a Felipe Lázaro ${ }^{231}$ editar póstumamente El regalo, el primer y único libro de Nelson que fuera publicado, con el mero deseo de recordarlo (Lázaro 13). En su nota en Arturo también escribe: "pienso en ese momento en que, granada en mano, sobrevolando la Isla con sus campos de trabajo y sus cárceles, Nelson se sintió libre, en el aire, quizás por única vez durante toda su vida. De ahí la dedicatoria del libro" (énfasis añadido, 82). Es indudable que este gesto, tanto la nota como el relato, es un intento por rescatar del olvido a su amigo, a quien no sólo se le negó la pertenencia a la nación por ser homosexual, sino que también fuera borrado del corpus literario nacional ${ }^{232}$ según el discurso de la oficialidad. Por otra parte, al aludir a los campos de trabajo y las cárceles,

\footnotetext{
${ }^{231}$ Director de la casa editorial Betania.

${ }^{232}$ En la introducción a la reedición que realizara la casa editorial Betania del libro de Nelson, Felipe Lázaro explica como la obra de este autor no apareció en el Diccionario de la Literatura Cubana (La Habana: I tomo, 1980 y II tomo, 1984).
} 
el intento de Arenas también se convierte en una contra-memoria de lo que fueran las UMAP: campos de trabajo forzado donde a los reclusos, bajo un sistema carcelario similar al de los esclavos, se les obligaba a trabajar, mayormente, en las plantaciones azucareras.

Desde el inicio del relato Arturo lucha contra lo que llama la "reduc[ción] de la dimensión de la tragedia, de la eterna tragedia del sometimiento, de su eterna desgracia", que ellos, el resto de los homosexuales confinados en el campo de las UMAP, "con sus infinitas conversaciones inútiles", "sus gestos excesivamente afeminados", "el barullo", "la risa", "el choteo" y "el marcado aleteo de las pestañas" minimizaban,

rebajándolo todo, corrompiéndolo todo, hasta [que] la auténtica furia del que padece terror, ... . el abusado ritual de las patadas, los culatazos en las nalgas, las bofetadas; . . . la ceremonia de un fusilamiento se convertía, se transformaba para ellos en un ajetreo de palabras rebuscadas, de poses y chistes de ocasión. (10)

Ante este comportamiento, que Arturo criticaba por vulgar y frívolo, pero que era, indudablemente, un acto de resistencia — si se tiene en cuenta que tanto la burla como el ser afeminado socavaban la solemnidad y la moral heteronormativa del discurso del régimen - Arturo propone la escritura, una obra donde lograra construir un mundo donde él y él pudieran vivir en libertad, un espacio donde no sólo se liberara de los horrores, pero donde fuera permitido manifestar abiertamente su homosexualidad. Tras haber sido víctima a la salida de un teatro de una de las redadas que se realizaran en La Habana, donde jóvenes eran recogidos por tener el pelo demasiado largo, por vestir de una forma determinada o, sobre todo, por ciertos rasgos, ciertas maneras (29), Arturo había sido transportado a un campo de las UMAP. Allí, había tenido que lidiar con un mundo "horrible" e "intolerable", relacionándose con el resto de los "maricones", "soportando 
interminables jornadas en el cañaveral", hasta convertirse como ellos en un "animal manso o agresivo por las cosas más insignificantes, ya sin recuerdos ni esperanzas para las cosas importantes" (14-15).

Socavaba Arenas —narrador-, desde estas primeras páginas, la idea de que los campos de las UMAP fueran espacios mesiánicos donde los jóvenes irían a salvarse. Allí, no sólo tenían que soportar los abusos de sus carceleros y el trabajo brutal, sino que también tenían que convivir e integrarse forzosamente a una comunidad, una categoría la de maricones - que no se escapaba de la vulgaridad y el colectivismo asfixiante que iba dominando ahora la sociedad. Ya antes del encierro, Arturo se preguntaba si "no eran entonces, [en el pasado], las tardes un poco más lentas, menos sofocantes" y si "no era la gente un poco más silenciosa", para luego sentenciar que todo, en el país, se podría (22). Después en el campo de trabajo forzado, cuando el resto de los confinados se burlaban de él por querérselas dar de "persona decente", Arturo comprendió que tanto los homosexuales que allí se encontraban, como los oficiales o integrantes, en general, de la sociedad no toleraban la indiferencia. "Traición, robo, ofensas, muerte, todo podía pasar, y de hecho pasaba, pero lo que no se admitía era que no se contase a la hora de cometer el delito ... con la inmensa chusmería, que no se confiase en ella, que no se sometiese a ella" (32). El campo se proyectaba como un espacio donde la privacidad y la individualidad no se respetaban, una especie de microcosmos de una sociedad donde abruptamente se iba borrando el individuo y aún peor, en este lugar, todo vestigio de la compasión humana:

desde hacía mucho tiempo ya no se les trataba como seres humanos, no les ponemos la bandera, les decían los oficiales, porque ustedes no son dignos de ella, y a ellos no les molestaba ni ésa, ni ninguna ofensa, las 
encontraban lógicas, estaban ya tan imbuidos en su desgracia que ésta era ya casi una extensión natural de ellos mismos, algo inevitable, incambiable, como un castigo a perpetuidad, como una maldición del tiempo, ellos tenían sus gritos, su modo de hablar, su estúpida jerigonza, y sobre todo . . . tenían esa mansedumbre, ese aceptar cualquier cosa . . . cualquier terror, cualquier ofensa, e incluirla inmediatamente entre sus tradiciones otorgándole una definición típica, incorporándolas al folclor, a las costumbres, a las calamidades diarias, así transformaban el terror en un ritual cotidiano. (36-37)

Más adelante narra los atroces castigos a los que eran sometidos los reclusos, horrendas escenas que bien pudieran pertenecer a los textos antiesclavistas decimonónicos analizados en este estudio o a la biografía novelada sobre Pedro Blanco, donde se describían las mortificaciones que sufrían los esclavos en las plantaciones azucareras durante la era colonial. Permanecer tres días completos al sol, ser enterrado hasta el cuello en el patio del campamento durante varias jornadas, el traslado de alguno sin que se supiera su paradero (37), eran algunas de las penitencias impuestas por los militares quienes, al igual que los negreros esclavistas de antaño, tenían total dominio sobre la vida de lo forzados.

Ante esta postura sumisa y, sobre todo, ante el silencio, Arturo decide rebelarse, "da[r] testimonio de todo el horror, comunicándole a alguien, a muchos, al mundo, o aunque fuese a una sola persona . . . la realidad" (38). Antes, para sobrevivir, había comprendido que tenía que integrarse y comenzó a imitar el mismo comportamiento de ellos, los mismos gestos excesivamente afeminados, la misma vulgaridad, los actos frívolos, pero ahora, a través de la escritura podría denunciar la realidad, la versión de los hechos de los que la padecen, aunque para él, la denuncia se tratara de la creación de un nuevo presente, de una realidad diferente y liberadora. Aquí el protagonista expresa una duda en cuanto a la eficacia de las palabras, ¿hasta qué punto podían las palabras contra 
el terror? Si los relatos, los recuentos, los análisis minuciosos no hacían más que afianzar la realidad, por ser una variación del mismo terror (44).

Esta postura, la necesidad de crear, a través de la escritura, un mundo diferente y liberador, lo acerca a aquellos escritos de los románticos donde se imaginaban un espacio idealizado. Si recordamos los poemas de Heredia aquí analizados — donde se construían paisajes nacionales, emancipadores, llenos de nostalgia, que desterraban la presencia española de la Isla, al igual que los parajes industriales con sus negros y sus cañas- se puede apreciar una similitud con la obra de Arenas. El mundo que imagina, a través de la escritura - también es un espacio idealizado donde no hay cabida para los horrores que ocurren en las plantaciones de las UMAP, ni para las prácticas homofóbicas de la sociedad, fundadas en una arraigada tradición, pero institucionalizas a través de las políticas sanitarias del régimen.

Por otra parte, esta necesidad de crear una realidad diferente, también se pudiera interpretar como un presagio y una exteriorización del deseo de la fuga y del valor de ésta por encima del de la palabra. Si las palabras no podían hacer nada contra el horror, la huida, sin embargo, pudiera vislumbrarse como una solución emancipadora. La escritura, el acto escapista con el cuál evadía y denunciaba los horrores del presente, exigía que Arturo se perdiera por intervalos breves para finalizar su obra. Las interrupciones, sin embargo, el tener que siempre regresar a su realidad, a su condición de esclavo, "donde siempre había un nuevo campo de caña quemada que cortar . . . un herbazal que arrancar . . . una piedra que remover" (62), obstaculizaban su proyecto. Para lograr terminar su creación, el verdadero acto de denuncia, necesitaba no tener que retornar a su existencia en los campos, de ahí que decidiera "ech[ar] a correr por entre el cañaveral y lleg[ar], 
libre y jadeante, hasta la explanada, hasta el gran sitio donde daría forma a su reino —el inmenso castillo - al margen de todos los terrores" (65-66).

En este sentido el acto de rebeldía de Arturo se asemeja al cimarronaje ${ }^{233}$. Mientras que los textos antiesclavistas denunciaban esta institución, recreando sus horrores, la única opción que el esclavo hallaba era fugarse, refugiándose en el monte, construyendo sus palenques, buscando su libertad. Una vez descubierta su ausencia, sin embargo, los militares, cual jauría de perros rancheadores, comienzan a buscarlo y encuentran sus escritos. En papeles, cartones, afiches, pancartas, había construido su obra, su acto de resistencia, que los carceleros sentencian de sandeces, boberías, palabras raras, que al final, eran cosas de maricones que no tumbaban a ningún gobierno (66-67). Luego, después de haber corrido por más de cuatro horas por los campos, finalmente lo encuentran, pero al no obedecer las órdenes de detenerse lo fulminan a disparos. Arturo, al igual que muchos negros fugitivos que eran hallados por los rancheadores, tenía un trágico final.

La versión histórica que en este relato Arenas escribe sobre los campos de las UMAP, ese texto apócrifo que al igual que el de Arturo se superpone, como un palimpsesto, a la Historia oficial, socava por completo el discurso de la separación, mostrando que los horrores de la plantación azucarera, lejos de haberse erradicado con la Revolución, se repiten. En este sentido, Arenas se convierte en un genealogista foucaultiano por localizar las voces que fueron anteriormente silenciadas y excluidas para insertarlas en su versión de la historia. Las experiencias de los forzados en los campos de

\footnotetext{
${ }^{233}$ En Literary Bondage: Slavery in Cuban Narrative (1990), William Luis habla de la novela de Arenas como una continuidad de la literatura antiesclavista decimonónica, específicamente de la figura de Juan Francisco Manzano, poeta esclavo miembro del círculo en torno a Domingo del Monte.
} 
las UMAP, otro capítulo oscuro de la historia azucarera cubana, se erige, gracias a este texto, como una contra-memoria de la nación.

\subsection{LA MEMORIA AZUCARERA DESDE LAS MÁRGENES: LA PRODUCCIÓN} CULTURAL ANTI-HEGEMÓNICA ANTE LA DEBACLE AZUCARERA

¿Y a quién le hablaremos de molienda,/ con las manos lejos del corte,/ de la caña ondulante que tampoco está? [... .]/ Pregúntenle a este enmudecido terraplén/ a qué sabe el azúcar de la desmemoria. Maylán Álvarez

En una exposición celebrada en la Galería Oscar Fernández-Morera ${ }^{234}$ en el año 2014, bajo el nombre "El dulce hábito de hablar"235, la artista plástica Mailén Fonseca exponía una video-instalación que consistía en una tribuna presidencial, hecha de cañas, colocada frente a una pantalla donde se proyectaba el video de un cañaveral. Como sonido, el espectador podía escuchar el rumor de las cañas movidas por el viento. La obra, que reunía dos entidades tan frecuentadas por la Revolución —el atril con sus micrófonos y la caña de azúcar-, además de darle voz a ésta última, también se pudiera interpretar como una ruptura entre ambas, que terminaba traduciéndose a un gesto de reproche dirigido al discurso oficial, por su silenciamiento ante las nefastas consecuencias de la reestructuración azucarera.

Además de esta pieza de Fonseca en los últimos años otros artistas contemporáneos también han recurrido a la temática del azúcar. Los arquitectos Teresa Ayuso y Juan Luis Morales, por ejemplo, como parte de su proyecto Patrimonio a la

\footnotetext{
${ }^{234}$ Localizada en la provincial de Sancti Spíritus.

${ }^{235}$ Los detalles acerca de esta instalación los obtuve gracias a Maikel José Rodríguez Calviño, narrador y crítico de arte, quien escribiera una nota periodística sobre este evento, titulada "Ecos del Morera: elogios de lo tridimensional", que fuera publicada en el periódico digital Escambray.cu el 6 de noviembre del 2014.
} 
deriva ${ }^{236} \mathrm{y}$ en homenaje a Eduardo Laplante, tras el cierre y desmantelamiento de los centrales azucareros en el año 2002, visitaron y fotografiaron los lugares donde se alzaban los ingenios que había inmortalizado este pintor y litógrafo francés con sus litografías. La serie, titulada Los ingenios (2004), conforma un conjunto de piezas en técnica mixta — gouache sobre impresión fotográfica — que muestra las ruinas de lo que fueran las antiguas fábricas. Las imágenes, a pesar de que los arquitectos quisieron retomar la visión idílica de Laplante en un afán por resaltar la belleza de las obras originales (Santiago, párr. 8), no dejan de ser desoladoras. De la mayoría de los ingenios decimonónicos apenas quedan las ruinas - incompletas - de alguna locomotora, parte de una maquinaria, los esqueletos de edificios colapsados y, en algunas ocasiones, lugares completamente abandonados.

Contrapuestas a las litografías originales — que mostraban aquel paisaje intermedio donde el hombre armonizaba a la naturaleza bucólica de la Isla, ya dominada por él, y a la máquina-, las ruinas o la ausencia de todo vestigio azucarero y la exuberante y silvestre naturaleza o, en ocasiones, un paisaje desolado con señas de deforestación, transmiten la sensación de un total abandono donde al hombre, lejos de glorificarse, se le recrimina. Las láminas de Laplante, además de una oda a la industria, y en especial a la máquina, eran también una apología pictórica a la gran sacarocracia cubana: protagonista de la riqueza y el progreso de la nación. Los ingenios de Ayuso y Morales, sin embargo, son un reclamo ante el abandono y la consecuente pérdida de un patrimonio natural y cultural tangible que, indudablemente, también va a tener una

\footnotetext{
${ }^{236}$ Además de Los ingenios, las series Los bohios (2003), Los balnearios (2007), Arqueología (2014) y Varaderos (2017) también conforman parte de este proyecto.
} 
repercusión en el patrimonio intangible de la nación, con desastrosas consecuencias humanas. Además de paisajes, edificaciones y fábricas, estas fotografías igualmente traslucen como se va perdiendo parte del saber, la tradición y la memoria azucarera, una pérdida que aunque no originaria dentro de la Revolución, ha llegado a dimensiones paradójicas dentro de ésta. La obra de este dúo, si bien enfocada en el patrimonio nacional, igual se puede enmarcar dentro del corpus cultural en torno a la reestructuración azucarera que ha creado un espacio para el dolor y la nostalgia.

Marcel Molina, por su parte, otro de los artistas que recurre a la ruina de la industria azucarera, y quien ha desarrollado a través del grabado toda una poética iconográfica en torno a la demolición de los centrales a raíz de la reestructuración, en su serie Desnudando el tiempo (2009), reunió un conjunto de serigrafías donde aparecen imágenes de centrales desmantelados junto a testimonios de personas que fueron afectadas por la restructuración. En una de ellas, bajo el caparazón desnudo de la nave de un ingenio y la torre de una chimenea, que se alza como recordatorio de un pasado grandioso contrastando con la triste realidad, se lee: "De mi nariz desaparecio (sic) el olor a mieles y azúcar/ en mi vista solo (sic) quedan ruinas y desolación”. Esta noble idea de integrar en su obra las voces de otros sujetos que sufrieron, al igual que él ${ }^{237}$, las consecuencias del desmantelamiento de la industria azucarera, va a contrastar ineludiblemente con la excluyente postura del régimen, que lejos de crear espacios para el sufrimiento y el trauma, se aferra al optimismo, a la descontextualización del evento en aras de minimizar sus drásticos efectos, cuando no, al silencio.

\footnotetext{
${ }^{237}$ Molina fue espectador de las drásticas consecuencias que produjo el cierre de los centrales azucareros alrededor del municipio de Cruces, en la provincia de Cienfuegos, en especial el central Mal Tiempo antiguo Andreíta-.
} 
En otra pieza de Molina, perteneciente a una serie posterior ${ }^{238}$, serán una infinidad de pequeñas naves dispuestas en forma de espiral las que dialoguen alrededor de una nave y una torre de un central azucarero, ambas en escala mayor. La obra se titula "Memorias" y dentro de sus posibles interpretaciones, me atrevo a proponer la idea del desencuentro entre la memoria oficial, las figuras en escala mayor con aires de triunfalismo, y las memorias individuales, pequeñas, marginadas, que no han tenido cabida dentro de este discurso. En otra de las obras de esta misma serie, titulada "El paraíso", serán una infinidad de tumbas las que están colocadas, también en espiral, alrededor de los caparazones de dos naves junto a dos chimeneas, en primer plano y otra al fondo. Una vez más la idea, simbolizada en las inmutables torres, de un discurso azucarero triunfalista por parte de la oficialidad, que se desentiende de la penosa realidad, pudiera ser la lectura de esta obra; aunque además se pudiera, y esto también es aplicable a la obra anterior, hablar de la memoria, de la permanencia de una memoria histórica representada en las torres - a pesar de la muerte de muchos centrales y la casi desaparición de la industria azucarera.

En una tercera obra, donde a mi entender el discurso se recrudece, es la figura, en una guardarraya frente a un cañaveral, de un campesino apoyado en un bastón, llevado del brazo por un esqueleto - típica figura de la muerte - que lo mira atenta y sonriente, la imagen que clama por la memoria. La pieza se titula "El testamento" (2012) e irónicamente es la muerte, su doble especular, quien escribe en una tablilla las memorias del anciano para la posteridad. Como elemento a destacar es la substitución del rostro del campesino por una huella dactilar que lejos de distinguirlo, lo convierte en una entidad

\footnotetext{
${ }^{238}$ Esta serie se titula La raíz que no florece (2010).
} 
colectiva, depositaria de la cultura y la memoria azucarera. El tópico de Memento mori, aunque iconográficamente en esta pieza muy parecido al género de la danza macabra ${ }^{239}$, no se utiliza como elemento unificador de la muerte, sino más bien como un recordatorio, una urgencia ante un legado azucarero, parte de la identidad nacional, que muere.

La urgencia, que en la obra de Molina también se trasluce a una especie de obsesión — producida por el trauma — que lo hace regresar, una y otra vez, a la misma temática, se pudiera interpretar como un sentir de la época que conlleva a actos de resistencia ante el silenciamiento oficial, a pesar de las drásticas consecuencias de la reestructuración azucarera. Maylán Álvarez, por ejemplo, al exponer las razones que la hicieron embarcarse en su proyecto testimonial, menciona como primer motivo "la total ausencia de noticias en los medios de difusión masiva sobre el otrora primer renglón económico del país y al desconocimiento del estado en el que se encontraban los bateyes" cuando, en realidad, el tema "merec[ía] libros, investigaciones o tesis de y sobre la gente del azúcar" (25).

En el caso de esta joven poeta y periodista, las memorias azucareras serán recogidas en un libro de testimonios personales y gráficos que destaca por su pluralidad. Álvarez, al igual Fonseca y Molina, comprende la necesidad de crear un espacio que le de voz a las personas que fueron afectadas por la reestructuración, en especial a sus víctimas directas. Más adelante explica que sentía una deuda moral personal:

Por varios años trabajé en el Sistema informativo de la televisión cubana en Matanzas y jamás se me orientó hacer un trabajo periodístico en torno a la industria azucarera y en ese mismo período se estaban cerrando en la provincia la casi totalidad de centrales, es decir, la única fuente de empleo

\footnotetext{
${ }^{239}$ La danza macabra o danza de la muerte es un género literario y figurativo muy popular en la Edad Media que constituye una gran sátira social donde se contempla la muerte como un elemento unificador de la humanidad sin contemplar los estamentos sociales.
} 
de un número importantísimo de familias matanceras. Parece que era un tema tabú, intocable, orientado desde "arriba" no comentarse. (26)

Más allá de su inconformidad ante la censura oficial, Álvarez destaca la envergadura de la reestructuración, que fuera de los trabajadores azucareros y sus familiares también había afectado a personas vinculadas a otros sectores, como las fábricas donde se producían y reparaban piezas y herramientas para los ingenios (25). Por otra parte, también enfatiza en la pérdida del patrimonio cultural intangible azucarero, o lo que pudiera llamarse la cultura del azúcar: vocablos, festividades, costumbres, tradiciones, entre otros, que fuera de este contexto fenecerían (27).

Algunas interrogantes de las que se planteó, y que la impulsaron a realizar su proyecto, son muy similares a las que expusieran algunos conferencistas en el seminario en torno al azúcar, convocado por la Asociación Fernando Ortiz en el año 2003 y analizadas en el primer capítulo de este estudio.

¿Y qué pasó en los lugares donde no había para extraer níquel, ni cobalto, ni petróleo, ni podían hacerse siembras de café, ni tenían atractivos geográficos o arquitectónicos para vender un producto turístico? . . ¿De qué iban a vivir esas personas cuyo nacimiento, crecimiento y desarrollo dependía de la cantidad de arrobas que caía al basculador durante seis, siete meses al año? (27)

A diferencia de los conferencistas, sin embargo, y muy probablemente porque la obra de Álvarez se realizó casi una década después — tiempo en el que pudo presenciar la magnitud de la debacle azucarera-, expone el impacto psicológico y las premuras que sufrieron algunos de los afectados:

A mi alrededor [he visto] demasiada incomprensión, dolor, nostalgia y alcoholismo, desempleo, juegos ilegales ... (26) Se separaron las familias que tuvieron que dejar el marco del batey. Se perdieron oficios heredados de padres a hijos y a nietos. Se dejó atrás el viejo central para buscar opciones laborales en municipios y ciudades, lejos del terruño. ... Se ha 
perdido parte de la historia patria, irremediablemente. Ya hay poco por legar a estas nuevas generaciones que solo conocen de oídas, en las noches de apagón en el mejor de los casos, el pito de las calderas, la emulación socialista y las tiendas de puntos. (27-28)

Es interesante apreciar como para Álvarez, parte de lo que se ha perdido, más allá del patrimonio cultural, está relacionado a la utopía de la Revolución. La mención a "la emulación socialista", al "honor azucarero", a "la voluntad viril de cortar caña a la luz de un mechón "porque la Patria lo necesita"”, a esa generación de "jóvenes cubanos [que] iban voluntarios y felices a los cortes a donar sus vacaciones" (28), es una prueba de cómo el discurso ideológico revolucionario en torno al azúcar llegó a calar en una parte de la población. Álvarez rememora los años de la euforia, aquellos primeros años que mencionaba Celdrán en su obra teatral y que fueron recogidos en el documental Oro de Cuba. Son años donde el discurso del régimen, como bien explicara Ana Serra, logró articular la participación en el corte de caña como un deber patriótico que fortaleció el sentido de unificación de la nación cubana (87). La nostalgia, expresada de esta manera, es una nostalgia postsoviética que contrasta grandemente con la literatura testimonial de Arenas, discurso narrativo sobre el trabajo forzado dentro de la Revolución que, a pesar del desenfado de esta obra de Álvarez, queda excluido de su rememoración sobre esta época.

En cuanto a los testimonios que se recogen en La callada molienda, no obstante, es muy importante enfatizar en su pluralidad. Aunque, en cierta medida, en esta obra todavía se trasluce el compromiso típico de la intelectualidad comprometida - los epígrafes citando textos de altos funcionarios de la cultura y de los líderes máximos ${ }^{240}$

\footnotetext{
${ }^{240}$ En una de las páginas iniciales se citan textos de Miguel Barnet, Eusebio Leal, Raúl y Fidel Castro.
} 
como prueba de ello- sí se reúnen testimonios donde se critican abiertamente las medidas tomadas por el régimen concernientes a la reestructuración y se exponen, sin reparos, las drásticas consecuencias de la misma. Por otra parte, como común denominador, incluso hasta en las posturas más oficialistas, se abandona la retórica triunfalista para hacer énfasis en el llamado síndrome del central. Las palabras y frases de exagerado optimismo no tienen cabida dentro de esta obra, donde predomina un tono melancólico que habla de la tristeza, la añoranza y el trauma.

Raúl García Iglesias, por ejemplo, en calidad de jefe de despacho del director de la empresa agroindustrial de la provincia de Matanzas, explica la diferencias entre las necesidades de la nación y las expectativas de la población. "No es solo echarle la culpa al Estado, ni a los problemas económico y financieros. ... El problema es más integral. Podemos hablar de sistema. El que está abajo ve su problema, el que dirige ve los problemas de forma integral” (81). A pesar de que entiende que la decisión estatal de cerrar los centrales era necesaria — postura que lo convierte en defensor y vocero de las políticas del régimen—, reconoce que fue muy dolorosa para todo el mundo porque los centrales eran el corazón, en todos los sentidos, de los ingenios.

Yo soy gente de campo también y cuando usted para un ingenio es como si le quitaras el sol [énfasis añadido]. . . . Un ingenio genera movimiento, transporte, genera comida. En tiempo de zafra se pone más énfasis en los puestecitos para que vendan más comida, para que haya siempre refresco, para que no falte el hielo. No puede faltar la guagua de transporte. El mismo camión que transporta caña, transporta gente que está en el batey. La corriente no falta. (80)

Es importante tener en cuenta que en un sistema totalitarista como la dictadura comunista cubana las necesidades de la nación son determinadas por el Estado, un grupo de personas —o un máximo líder- que no fueron elegidas democráticamente, pero que 
deciden el futuro de la Isla sin que a la ciudadanía se le de participación. Por otra parte, también es preciso entender que el sector económico estatal, que es el que rige la economía azucarera en Cuba, es el encargado de proveer todos estos medios, mencionados por García, a los ingenios. En tiempos de zafra, como bien explica, eran destinados muchos más recursos a estas comunidades, justamente para estimular a la población y asegurar una buena molienda. Una vez que se cierran los centrales y los ingenios dejan de aportar a la economía centralizada del país, el Estado, aunque García no lo diga explícitamente, deja de destinar recursos a estas poblaciones. Como consecuencia, la vida económica de los bateyes se paraliza, teniendo un impacto desastroso en sus habitantes.

Más allá de las carencias económicas, no obstante, la mayoría de los testimonios expresan el vacío producido por el desarraigo. María Laura Martín, quien trabaja para la Oficina de Monumentos y Sitios Históricos en Matanzas, entiende que la Tarea Álvaro Reynoso golpeó profundamente a los hombres y mujeres amantes del azúcar:

Esas personas de los bateyes sufrieron un pérdida de identidad, fue un golpe en su vida. Muchos azucareros, lo sé por el testimonio de los que aún viven en esos lugares, enfermaron y murieron por estados depresivos, por estados de desolación, del golpe mortal a su amor por el azúcar. (86)

Reinaldo Castro Yedra, el machetero millonario que fuera seleccionado primer Héroe del Trabajo — nombrado en este estudio cuando se analizó el documental Oro de Cuba-, aunque asegura que ninguna persona ha quedado desamparada gracias al Estado, reconoce que la reestructuración "[t]rajo tristeza, [] desencanto" y opina que "con la desaparición de los centrales [.. .] mucha gente ha envejecido antes de tiempo.... gente que podía haber vivido cuatro o cinco años más y han fallecido porque eran cañeros de 
toda una vida" (109-110).

Manuel Fuentes Torres, mecánico de equipos de medición de un central, narra la tristeza y el trauma que le produjo encontrar ahorcado a un amigo de trabajo, quien tras el cierre de su central cayó en una profunda depresión y terminó suicidándose. "La gente [cuenta Fuentes] le achaca problemas familiares, pero no, en la familia siempre hay dificultades [... ] fue lo del central, él se deprimió" (168).

Luis Pita Suarez, por su parte, es un tecnólogo azucarero cuyo testimonio se concentra en la añoranza:

Todavía sueño a menudo con el ingenio. No hace ni cuatro días que yo soñé que estaba en el ingenio, que había problemas y que tenía que ir y que tenía que luchar para que el ingenio no se parara. Muchas veces sueño con él, porque era parte de la vida de uno. (171)

Aunque algunos testimonios se van a concentrar en la pérdida del patrimonio azucarero, otros van a mencionar la ineficiencia y el desorden con que fue llevada a cabo la reestructuración —algo que permitió el latrocinio en algunos centrales- y otros denunciaran las soluciones horrorosas y antiéticas adoptadas en la industria, una vez que se dejó de recibir la ayuda soviética, todos coincidirán en que el cierre de los centrales fue para la gente del azúcar una experiencia traumática. Carlos Lage, vicepresidente del Consejo de Estado, a raíz de la reestructuración, había afirmado:

Todos nos percatamos de la importancia de la reestructuración de la industria azucarera para el futuro y para el desarrollo del país, e incluso nos percatamos de que estamos ante un proceso que puede dar un ejemplo al mundo de cómo se pueden enfrentar los retos de la economía sin convertir al trabajador en víctima de la reestructuración, sino de beneficiario de esta cuando se lleva a cabo una política de justicia social. (cit. en Álvarez 38)

Los testimonios recogidos en La callada molienda, sin embargo, demuestran que 
los trabajadores azucareros y todas las personas que de cierta manera estaban ligadas a la cultura del azúcar, sí terminaron siendo víctimas de la debacle. La magnitud del acontecimiento, a pesar de la retórica triunfalista del discurso oficial, terminó ocasionando consecuencias ominosas en la población. El cierre de los centrales no sólo dejó a la mayoría de los habitantes de los bateyes viviendo en condiciones aún más precarias, sino que también tuvo un fuerte impacto psicológico en estas comunidades; impacto que se pudiera definir como un trauma cultural, al ser la reestructuración un evento terrible que dejó huellas indelebles en la conciencia grupal, marcando su memoria para siempre y cambiando su identidad futura de manera radical e irrevocable (Alexander 1). Esta obra, al concentrarse mayormente en el dolor y en el trauma, en la sensación de desarraigo que sintieron los damnificados producto de la pérdida de sus referentes culturales, se enmarca, como texto de resistencia ante el silenciamiento oficial, dentro del corpus cultural anti-hegemónico que se produjo a raíz de la ruina azucarera.

Siguiendo la línea testimonial de Álvarez, en el año 2004, dos años después de iniciada la crisis, Alejandro Ramírez Anderson también rompería el silencio y sorprendería a la audiencia con su documental DeMoler (2004). A diferencia de la mayoría de los documentales realizados por el ICAIC acerca del azúcar, donde el individuo se diluía en la colectividad para articular la comunidad imaginada, Ramírez rescata con esta obra al sujeto de la epopeya nacional. Alejado de la retórica triunfalista y adoctrinadora, que con claros fines didácticos servía para convocar a las masas a incorporarse al corte de caña, o para convencer, por ejemplo, a los zafreros sobre la importancia del trabajo en brigada o de la mecanización — como se pudo apreciar en el análisis del documental Oro de $\mathrm{Cuba}$-, se adentró este joven realizador en la provincia 
de Guantánamo, al Oriente de la Isla, para documentar la realidad de los habitantes del batey Paraguay (antiguo Las Cañas). Lejos de la premura y el tono patriótico que exigían las zafras, rememoran los entrevistados su vida azucarera y expresan sus opiniones acerca de la reestructuración. Son los testimonios íntimos, las memorias comunes de los más afectados, de quienes entregaron su vida a los centrales - testimonios que en su mayoría traslucen la nostalgia, el trauma y el dolor.

Luego de unas primeras imágenes del central, acompañadas por sus ruidos, la cámara recorre un cañaveral. Las cañas, dulcemente movidas por el viento - como las describieran Acosta y Pichardo casi un siglo atrás - apelan al mundo sensorial y a partir de este momento, le devuelve Ramírez a los zafreros y a los demás habitantes del pueblo los lugares de la memoria —en el sentido que lo entendiera Pierre Nora ${ }^{241}$, como lugares donde se cristaliza la memoria colectiva. La maquinaria del central, sus torres, los campos de caña y las edificaciones del batey, son lugares con los que los pobladores mantenían una relación sentimental, íntima. Gracias a ellos, pueden ahora evocar las moliendas en sus anécdotas personales, que, aunque no evaden lo colectivo, porque evidencian el sentido de la comunidad, sí se alejan de la retórica triunfalista del discurso del poder. "La alegría del pueblo era la zafra, el central" (00:01:28-32) comenta la cocinera con cierta angustia. "El ruido del central le da alegría a la gente" (00:03:12-16), "el olor a miel o a melaza, eso a uno le da gusto sentirlo" (00:03:28-36), aseguran nostálgicos uno de los trabajadores y el director de la fábrica. Otro trabajador explica que "la gente esperaban (sic.) la zafra para pasear, para venir aquí al central a ver como

\footnotetext{
${ }^{241}$ Referencia a la obra Les Lieux de Mémoire (1984-1992), traducida al español como Los lugares de la memoria.
} 
molía, el olor a caña, a guarapo" (00:04:18-25). Son las memorias biográficas intentando anteponerse a las memorias oficiales o de estado, las que se centran en el individuo en busca de sí mismo y su pasado, a diferencia de aquellas que lo despojan de su individualidad para poder vincularlo directamente a la Historia.

Esta primera parte del documental es muy significativa porque los lugares de la memoria van a recuperar una significación que se desentiende del discurso poder. De la misma manera que el régimen se aproximaba a la Historia a través de su uso monumental, iba construyendo, paulatinamente, lugares de la memoria. Cuando durante los primeros años de la Revolución se renombraron los centrales azucareros y tanto los nombres en inglés como los que aludían al catolicismo - incluso, los nombres femeninos- fueron sustituidos por nombres de líderes de la clase obrera, mártires de la Revolución y países de América Latina, se iban creando lugares de la memoria, en este sentido, dominantes. Más allá de los centrales, poco a poco el poder también fue significando otros lugares vinculados al azúcar - tanto físicos como inmateriales. Slogans y carteles que convocaban a las zafras, conmemoraciones y monumentos relacionados a la Historia azucarera, entre otros, no sólo recreaban mitos legitimadores sino que también inscribían al individuo dentro del epos nacional.

A raíz de la reestructuración, en aras de minimizar $-\mathrm{y}$ hasta silenciar- las nefastas consecuencias que esta medida ha ocasionado en las comunidades azucareras, estos lugares han sido frecuentemente revisitados por el régimen en un afán de forzar la memoria de la colectividad. La mención de la esclava Carlota como líder de la sublevación de esclavos en el Ingenio Triunvirato; la alusión al levantamiento de Carlos Manuel de Céspedes en el ingenio La Demajagua, con el que se iniciaron las guerras de 
independencia cubana e, incluso, los recién creados museos del azúcar, son ejemplos claros de la importancia que tienen estos lugares a la hora de mantener las memorias de estado. Ramírez, por su parte, se va a encargar de recoger y compartir las memorias individuales, un ejercicio mnemónico donde se le da voz a los afectados, que termina desmantelando las memorias dominantes del discurso oficial.

Después de la primera parte del documental, que se pudiera describir como la dulce rememoración del tiempo de las zafras, van a aparecer los relatos de la nostalgia y el trauma, donde los zafreros expresan su dolor y su inconformidad ante la reestructuración. Las lastimosas imágenes y los lacerantes ruidos narran ahora la demolición. Hay en estas escenas una recodificación de los lugares. El desmantelamiento del central le imprime al lugar $-\mathrm{y}$ a la memoria que evoca — un marcado sentido de desplazamiento. Si simbólicamente la reestructuración se podía leer como el retorno de los héroes a la realidad, la expulsión de la epopeya nacional —una especie de expulsión del paraíso azucarero-, la demolición, en manos de los mismos zafreros, se les provoca como un forzado homicidio. "Era como si se te muriera una madre o un hijo, que después de haberla construido uno mismo tengo que desbaratarla y desarmarla" (00:06:23-28), expresa uno de los trabajadores en su testimonio. "Por mucho que me digan, no he estado de acuerdo" (00:06:45-49), "a todo esto yo no le encuentro ni pies ni cabeza" (00:06:5156), manifiestan otros, expresando claramente su inconformidad. La comunidad se debatía ante la incomprensión y la incertidumbre. El tiempo muerto había llegado, esta vez para quedarse, y para anunciar la inminente pérdida de los referentes culturales e identitarios de los habitantes del batey, sus lugares de la memoria.

Este mismo sentido de desplazamiento es el que sufren los protagonistas de 
Melaza (2012), largometraje de ficción de Carlos Lechuga, rodado en el central Habana Libre (antiguo Habana) ${ }^{242}$, en la actual provincia de Artemisa. A diferencia del central que documentara Ramírez, Melaza es uno de los pocos centrales que ha quedado de reserva, y aunque temporalmente cerrado — como clama la voz en off de la locutora de radio en el filme - no fue desmantelado. Quizás esta idea de que las zafras volverán al batey, es la que permite que Mónica (uno de los personajes protagónicos) continúe ejerciendo sus labores en el central —inspeccionando las máquinas, dando detallados reportes telefónicos acerca de su funcionamiento-; mientras que su compañero sentimental, Aldo, el maestro de la escuelita destartalada para los niños del pueblo, enseña en una piscina averiada y vacía clases de natación a sus alumnos.

Hay en estas imágenes una insistencia por prolongar una rutina diaria que en el pasado tenía un sentido, una nostalgia por los años en que tanto la política azucarera como la educación alimentaban la utopía revolucionaria, una nostalgia postsoviética. De cierta manera se pudiera hablar de una negación de la realidad para aferrarse al sueño de una comunidad imaginada: la perfecta sociedad del hombre nuevo. Dentro del letargo que los domina, no obstante, la precariedad del presente los ha forzado ha encontrar un medio que malamente les ayuda a sobrevivir: de vez en cuando le alquilan a una amiga de Mónica que ejerce la prostitución el miserable tráiler donde habitan, para que mantenga ahí las relaciones sexuales con sus clientes. Como no tienen licencia para alquilar y no le pagan impuestos al Estado, terminan recibiendo una multa desorbitante, que lejos de escarmentarlos, los obliga a continuar usando medios ilegales, aunque tocando fondos

\footnotetext{
${ }^{242}$ Para efectos de la película el nombre original del central no se menciona y tanto el central como el batey se llaman Melaza.
} 
más bajos y moralmente mucho más cuestionables: ahora es Mónica quien se tiene que prostituir.

A diferencia del documental de Ramírez, en este largometraje no se exponen testimonios donde nostálgicamente se evocan las zafras o se expresa la inconformidad ante la reestructuración. Son más bien las escenas donde priva el silencio del pueblo y sus verdes paisajes azucareros - la constante imagen del rumor de las cañas mecidas por el viento-; el mutismo y la terquedad de los personajes, quienes se resisten a aceptar la nueva realidad, y el central y las residencias del batey en ruinas, las que narran la existencia de un pasado mejor. Ramírez había captado el momento en que una fábrica se desmantelaba, cuando sus habitantes se encontraban en un estado de profunda conmoción viendo como su vida — el central— se reducía a la nada. La obra de Lechuga, por su parte, se pudiera interpretar como el capítulo posterior que, más allá del trauma humano por la pérdida de los referentes culturales, también va a mostrar las soluciones alternativas (casi siempre ilegales) a las que algunos $-\mathrm{o}$ muchos - tuvieron que acudir, para poder sobrevivir el negativo impacto económico de la debacle azucarera. El Estado, lejos de ser la institución protectora de las personas afectadas por esta crisis, se convierte, con sus asfixiantes arbitrariedades legislativas, en su directo opresor. La obra de Lechuga, al igual que el resto de las obras reunidas en este acápite, funciona como un texto discursivo que se resiste a la versión monumental y triunfalista del discurso oficial en torno a la reestructuración azucarera. 


\section{CONCLUSIONES}

A partir del año 2002, con la puesta en marcha del plan de reestructuración azucarera, que estipulaba el cierre y desmantelamiento de gran parte de los centrales de la Isla, lo que realmente se presenciaba era la debacle azucarera cubana. El azúcar, que desde mediados del siglo XVIII se había convertido en un reglón imprescindible para la economía de la Isla y que durante los próximos dos siglos se entronizara como su producto principal, perdía, a la entrada del milenio, bruscamente su protagonismo. La magnitud de la medida sería extraordinaria. Más allá de lo que significara para la economía de un país cuyo sistema económico profundiza y perpetua la pobreza, se trataba de un acontecimiento que removía los cimientos de la Historia, la identidad y la cultura cubana. Cuba era una isla de azúcar o un monstruo diabético — como la llamara Sartre—, una nación que se imaginó y se construyó a partir de esta gramínea.

La heterogeneidad etnorracial y cultural, el sincretismo religioso, el surgimiento y crecimiento de las ciudades, las calles, los caminos, las edificaciones y el paisaje, entre muchos otros, fueron elementos influenciados por la agroindustria azucarera. También ligado a ella se encuentran el cimarronaje, los rancheadores, la desaparición de los bosques, el ferrocarril, las intervenciones estadounidenses, el tiempo muerto y, en décadas más recientes, las zafras del pueblo, las UMAP, los 10 millones que no se produjeron y la sovietización del país. La presencia del azúcar en la Isla, indiscutiblemente, ha sido trascendental y totalizante - aunque no sin contradiccionesde ahí que su casi desaparición sea un acontecimiento extremadamente significativo.

Con el propósito de reflexionar acerca de la envergadura de este suceso, este estudio ha trazado un mapa histórico cronológico circular, que inicia con el análisis de la 
representación de este acontecimiento según el discurso oficial y cierra con el examen de un corpus cultural anti-hegemónico que ofrece una versión alternativa acerca del impacto de la debacle azucarera. La existencia de dos discursos contrapuestos en torno al azúcar, sin embargo, no es algo que haya surgido a raíz de la reestructuración, ni tampoco en la era revolucionaria. Desde los inicios de la expansión de la industria azucarera existieron dos posturas antagónicas que se pronunciaron a favor o en contra del azúcar, dicotomía que es posible rastrear y reencontrar en cada período de la historia literaria y cultural de la nación cubana.

En este estudio he retomado estas dos posturas — que más adelante Antonio Benítez Rojo definiera como el discurso de la plantación azucarera y el discurso de resistencia anti-azúcar - para examinar la presencia e influencia que tuvieron en la construcción de la identidad y la cultura nacionales. Partiendo de las ideas del propio Benítez Rojo — quien también halla en estos discursos textos fundadores de la nación-y teniendo en cuenta que el azúcar y sus discursos continuaron - y aún continúandefiniendo la nación y parte de la cultura cubana, he analizado un corpus amplio y heterogéneo que incluye artículos y notas de prensa, discursos, ponencias, textos de naturaleza jurídico-económica, poemas, novelas, litografías, documentales, videoinstalaciones y literatura testimonial, entre otros. El examen de este ecléctico corpus, además de ratificar la ubicuidad del azúcar en todas las esferas de la sociedad, incluyendo la producción cultural, me ha permitido ilustrar de modo cronológico la presencia constante de un discurso polarizado en torno al azúcar — hegemonía vs. márgenes - en el devenir histórico de la nación cubana.

De esta polarización recurrente y muchas veces contradictoria, deriva una visión 
compleja y abarcadora del azúcar cubano, que va más allá de su estatus de símbolo positivo o negativo de la nación. De la combinación de perspectivas desde las que se enfoca y se narra "el motivo del azúcar" emana la verdadera y doble dimensión en que históricamente el azúcar se ha inscrito; una dimensión que, como reza el título de este estudio, contiene un lado dulce y otro agrio. En el recorrido que propongo he transitado ambas facetas, mostrando las maneras en que el azúcar se ha vinculado — dialogandocon conceptos relativos al discurso, la construcción nacional, la historia, el paisaje y la memoria, desde la era colonial hasta el presente.

Uno de los objetivos fundamentales de este estudio, y de hecho la causa de su origen, ha sido destacar la existencia de un corpus narrativo, iconográfico y fílmico, surgido a raíz de la reestructuración azucarera y en respuesta a los textos producidos por la oficialidad en torno a este acontecimiento. Dicho corpus ha creado un espacio alternativo — contestatario- que deconstruye la versión oficial de los hechos al enfocarse, mayormente, en el impacto que a nivel humano ha causado la debacle azucarera; un impacto que el régimen ha minimizado e, incluso, silenciado, como bien muestran los textos oficialistas analizados en este trabajo. La inclusión y examen de este corpus dentro de mi investigación los he realizado con el motivo de contribuir a su rescate, sistematización y visibilidad, porque es en estas obras, y no en el discurso oficial, donde, evidentemente, se ha representado el lado traumático, devastador y amargo de la reestructuración, por lo que cualquier estudio que prescinda de ellas, será indudablemente parcial e incompleto. La postura alternativa y disidente asumida en este conjunto de obras, no obstante, no flota en un vacío histórico, ni es absolutamente novedosa, muy por el contrario, ha estado presente de diversas maneras y con móviles 
diversos en la historia de la producción cultural cubana, manifestándose como una especie de continuum narrativo que se resiste al poder.

Además de estas obras que ofrecen una versión alternativa acerca de la debacle azucarera, he considerado importante subrayar dentro de este corpus la existencia de un conjunto de textos en torno al trabajo forzado en las plantaciones azucareras durante la primera década de la Revolución. Una parte de estos textos explora los temas relacionados con la ley del Servicio Militar Obligatorio — bajo la cual miles de jóvenes fueron recluidos en unidades militares en zonas agrícolas y obligados a incorporarse al corte de caña. La otra parte se ocupa de la versión más abyecta de estos campos militares, las famosas UMAP. Estos eventos, al igual que los efectos de la reestructuración, han sido falseados y casi siempre negados desde la oficialidad. El discurso oficial $-\mathrm{y}$ su cultura - nunca ha creado un espacio donde verdaderamente se pueda narrar la experiencia traumática que constituyó para los jóvenes la reclusión e incorporación forzada al corte de caña. Los textos que aquí analizo surgen precisamente en respuesta a este vacío, desde ellos se representa el horror y la injusticia de esos aciagos años, mostrando el costo humano de un capítulo oculto de la historia azucarera cubana. Si bien estas obras han sido ya estudiadas desde múltiples perspectivas, su conexión a este extenso y heterogéneo corpus del azúcar — que aquí he intentado sistematizar - hace que se logren visualizar dentro de un contexto histórico mucho más amplio.

El azúcar, desde su expansión a finales del siglo XVIII y hasta la actualidad, ha definido a la nación, su historia, su cultura. En este estudio he explorado su presencia constante y totalizadora, sistematizando e integrando, en un corpus concreto, un conjunto de textos heterogéneos con el azúcar como denominador común. Además de identificar y 
deslindar este corpus, mi estudio lo inserta y lo discute en el amplio marco histórico referencial del devenir del azúcar como símbolo de la nación cubana, estableciendo un diálogo enriquecedor y productivo entre los textos, su contexto de producción, y el contexto histórico general en que este corpus azucarero se gesta. Como parte de esa discusión, mi trabajo documenta y destaca la relevancia que, desde el punto de vista histórico y político, debe adjudicársele a un grupo de obras recientes, surgidas en respuesta a la reestructuración, llamando la atención hacia la importancia capital de estos textos para la reconstrucción fidedigna del impacto humano causado por la debacle azucarera cubana. 


\section{BIBLIOGRAFÍA}

“10 millones”. Dir. Carlos Celdrán, Argos Teatro, 6 jul. 2016, Argos Teatro, Ciudad Habana, Cuba.

"A mal tiempo .. . cambiarle la cara a la zafra". Ordenamiento de la economía en el segundo semestre. Granma. 5 de julio de 2016. Red. 17 sep. 2017.

Abril de Girón. Dir. José del Campo. Distribuidora desconocida, 1966. Filme.

Acosta, Agustín. La zafra. La Habana: Editorial Minerva, 1926. Impreso.

Acosta, Nilson. "Intervenciones". Seminario de la cultura del azúcar en Cuba. Catauro Revista Antropológica Cubana 6.11 (2005): 73-77. Impreso.

Aínsa, Fernando. De la Edad de Oro al Dorado: génesis del discurso utópico americano. México D.F.: Fondo de cultura económica, 1992. Impreso.

Alexander. Jeffrey C. "Toward a Theory of Cultural Trauma". Cultural Trauma and Collective Identity. Berkeley: University of California Press, 2004. Impreso.

Álvarez, José. “The Current Restructuring of Cuba Sugar's Agroindustry”. Gainsville: University of Florida, 2004. Red. 8 sep. 2017.

Álvarez Rodríguez, Maylán. La callada molienda. La Habana: Ediciones La Memoria, 2013. Impreso.

Arango, Rubén C. La sacarocracia: historia de la aristocracia azucarera cubana. Miami: Ego Group, 2006. Impreso.

Arango y Parreño, Francisco de. "Discurso sobre la agricultura de La Habana y medios para fomentarla". Francisco de Arango y Parreño. Obras (Volumen I). La Habana: Ediciones Imagen Contemporánea, 2005. 144-198. Impreso.

---. "Ideas sobre los medios de establecer el libre comercio de Cuba y de realizar un empréstito de veinte millones de pesos". Francisco de Arango y Parreño. Obras (Volumen II). La Habana: Ediciones Imagen Contemporánea, 2005. 142-155. Impreso.

---. "Nuevo reglamento y arancel que debe gobernar en la captura de esclavos cimarrones”. La Habana: Imprenta de la Capitanía General, 1796. Impreso.

---. "Oficio acompañando copia de la representación sobre la introducción de negros, y corroborándola con razones muy sólidas". Francisco de Arango y Parreño. Obras (Volumen I). La Habana: Ediciones Imagen Contemporánea, 2005. 138-139. 
Impreso.

---. "Primer papel sobre el comercio de negros". Francisco de Arango y Parreño. Obras (Volumen I). La Habana: Ediciones Imagen Contemporánea, 2005. 117-121. Impreso.

---. "Representación al rey sobre la extinción del tráfico de negros y medios de mejorar la suerte de los esclavos coloniales". Francisco de Arango y Parreño. Obras (Volumen II). La Habana: Ediciones Imagen Contemporánea, 2005. 334-340. Impreso.

---. "Representación hecha a su majestad con motivo de la sublevación de esclavos en los dominios franceses de la isla de Santo Domingo". Francisco de Arango y Parreño. Obras (Volumen I). La Habana: Ediciones Imagen Contemporánea, 2005. 140-143. Impreso.

---. "Representación manifestando las ventajas de una absoluta libertad en la introducción de negros, y solicitando que se amplíe a ocho la prórroga concedida por dos años". Francisco de Arango y Parreño. Obras (Volumen I). La Habana: Ediciones Imagen Contemporánea, 2005. 131-135. Impreso.

Arenas, Reinaldo. Antes que anochezca. México, D.F.: Tusquets Editores México, 2013. Impreso.

---. Arturo, la estrella más brillante. Miami: Ediciones Universal, 2001. Impreso.

---. El Central. Barcelona: Editorial Seix Barral, 1981. Impreso.

---. "Si te llamaras Nelson (A un joven norteamericano). Voluntad de vivir manifestándose. Buenos Aires: Córdoba: Adriana Hidalgo Editora, 1989. Impreso.

Argullol, Rafael. La atracción del abismo: un itinerario por el paisaje romántico. Barcelona: Editorial Bruguera, 1983. Impreso.

Arrate y Acosta, José Martín Félix de. "Llave del Nuevo Mundo. Antemural de las Indias Occidentales. La Habana descrita: Noticias de su fundación, aumentos y estados". José Martín Félix de Arrate. Primeros historiadores siglo XVIII. Ciudad de La Habana: Ediciones Imagen Contemporánea, 2005. Impreso.

Ayuso, Teresa y Juan Luis Morales. Los ingenios. Patrimonio a la deriva (serie de 25 imágenes). 2004. Gouache sobre impresión fotográfica.

Azahares, Tania. "Bayamo recibió el XV Encuentro Nacional de Patrimonio Histórico Azucarero". Azcuba.cu.19 de noviembre del 2014. Red. 10 ago. 2016. 
Báez, Luis y Pedro de la Hoz. Caravana de la libertad. Ciudad de la Habana: Casa Editora Abril, 2009. Impreso.

Balboa, Silvestre de. Espejo de paciencia. Ed. Raúl Marrero-Fente. Madrid: Ediciones Cátedra, 2010. Impreso.

Barcia, Manuel. "El Conde de Villanueva y la alternativa de la Cuba Grande: Una aproximación a la labor de Claudio Martínez de Pinillos al frente de la Intendencia de Hacienda de la Isla de Cuba, 1825 - 1851”. Francisco Arango y la invención de la Cuba azucarera. Ed. M. ${ }^{a}$ Dolores González-Ripoll e Izaskun Álvarez Cuartero. Salamanca: Ediciones Universidad de Salamanca, 2009. 289299. Impreso.

Barcia, María del Carmen. "Intervenciones". Seminario de la cultura del azúcar en Cuba. Catauro Revista Antropológica Cubana 6.11 (2005): 93-94. Impreso.

Barnet, Miguel. "La cultura que generó el mundo del azúcar”. Seminario de la cultura del azúcar en Cuba. Catauro Revista Antropológica Cubana 6.11 (2005): 6-15. Impreso.

Barreda, Pedro: "Vestirse al desnudo, borrando escribirse: El central, de Reinaldo Arenas". Boletín de la Academia Puertorriqueña de la Lengua Española 12.2 (1984): 25-37. Impreso.

Béjar, Eduardo C. La textualidad de Reinaldo Arenas: juegos de la escritura postmoderna. Madrid: Editorial Playor, 1987. Impreso.

Benítez Rojo, Antonio. “Azúcar, poder y literatura”. Cuadernos Hispanoamericanos. 451452 (1988). Impreso.

---. “Cirilo Villaverde, fundador”. Revista Iberoamericana 57.152-153 (julio-diciembre 1990): 769-76. Impreso.

---. "De nuevo la ponzoña". Casa de las Américas 62 (septiembre-octubre 1970): 126127. Impreso.

---. La isla que se repite: El Caribe y la perspectiva posmoderna. San Juan: Editorial Plaza Mayor, 2010. Impreso.

Bertot, Lillian. "Figuras y tropos de la opresión en la obra de Reinaldo Arenas". Reinaldo Arenas: recuerdo y presencia. Ed. Reinaldo Sánchez. Miami: Ediciones Universal, 1994. 63-75. Impreso.

Bonné Carcasés, Félix. "La homofobia alrededor de Carlota". Cubanet. 9 de noviembre de 2015. Red. 18 ene. 2018. 
Borrego, Juan Antonio. "Azucareros no quieren 'casualidades' con la zafra”. Granma 10 de noviembre de 2015. Red. 20 de sep. 2016.

Burin, Erin. Slavery and the Peculiar Solution: A History of the American Colonization Society. Gainsville: University Press of Florida, 2005. Impreso.

Camacho, Jorge. Miedo negro, poder blanco en la Cuba colonial. Madrid: Iberoamericana, 2015. Impreso.

Cantero, Justo G. y Eduardo Laplante. Los ingenios: colección de vistas de los principales ingenios de azúcar de la Isla de Cuba. Ed. Luis Miguel García Mora y Antonio Santamaría García. Madrid: Centro de Estudios y Experimentación de Obras Públicas, 2005. Impreso.

Carreras, Julio Ángel. Esclavitud, abolición y racismo. La Habana: Editorial Ciencias Sociales, 1985. Impreso.

Casas, Bartolomé de las. Brevísima relación de la destrucción de las Indias. Ed. André Saint-Lu. Madrid: Ediciones Cátedra, 2011. Impreso.

Castro, Fidel. Discurso pronunciado por el Comandante Fidel Castro Ruz, Primer Ministro del Gobierno Revolucionario de Cuba, durante el almuerzo ofrecido por la Asociación Americana de Editores de Periódicos, con motivo de su visita a Estados Unidos, en el Hotel Statler, el 17 de abril de 1959. www.cuba.cu. 16 ago. 2016.

---. Discurso pronunciado por el Comandante Fidel Castro Ruz, Primer Secretario del Comité Central del Partido Comunista de Cuba y Primer Ministro del Gobierno Revolucionario, en el Acto Central en Conmemoración del XXI Aniversario del Ataque al Cuartel Moncada, efectuado en la explanada frente al Estado Mayor del Ejercito Central, en Matanzas, el 26 de julio de 1974, "Año de XV Aniversario". www.cuba.cu. 20 ago. 2016.

---. Discurso pronunciado por el Comandante Fidel Castro Ruz, Primer Secretario del Comité Central del Partido Comunista de Cuba y Primer Ministro del Gobierno Revolucionario, en el Resumen de la Velada Conmemorativa de los Cien Años de Lucha, efectuada en La Demajagua, Monumento Nacional, Manzanillo, Oriente, el 10 de Octubre de 1968. www.cuba.cu. 19 ago. 2016.

---. Discurso pronunciado por el Presidente de la República de Cuba, Fidel Castro Ruz, en el acto inaugural de los Cursos de Superación para Trabajadores Azucareros, en áreas del central "Eduardo García Lavandero", en el municipio de Artemisa, el 21 de octubre del 2002. www.cuba.cu. 20 jul. 2016. 
---. Discurso pronunciado por Fidel Castro Ruz, Presidente de la República de Cuba, en la concentración celebrada en la Plaza de la Revolución "José Martí", para proclamar a Cuba Territorio Libre de Analfabetismo, el 22 de diciembre de 1961. www.cuba.cu. 15 sep. 2016.

---. Discurso pronunciado por Fidel Castro Ruz, Presidente de la República de Cuba, en las honras fúnebres de las víctimas del bombardeo a distintos puntos de la república, efectuado en 23 y 12, frente al cementerio de Colón, el 16 de abril de 1961. www.cuba.cu. 18 feb. 2018.

Cause, Cos. "El viejo". Casa de las Américas 62 (septiembre-octubre 1970): 184. Impreso.

Certeau, Michel de. La escritura de la historia. Trad. Jorge López Moctezuma. México: Universidad Iberoamericana, 2006. Impreso.

Céspedes, Úrsula. "Los negros del palenque”. En Poesías, selección y prólogo de Juan J. Remos. La Habana: Ministerios de Educación, 1948. Impreso.

Cohen, Jeffrey Jerome. "Monster Culture (Seven Theses)". Monster Theory: Reading Culture. Ed. Jeffrey Jerome Cohen. Minneapolis: University of Minnesota Press, 1996. 3-25. Impreso.

Colón, Cristóbal. "Diario del primer viaje". Cristóbal Colón: Textos y documentos completos. Ed. Consuelo Varela. Madrid: Alianza Editorial, 1992. Impreso.

Conducta impropia. Dir. Néstor Almendros y Orlando Jiménez Leal. Cinevista, 1984. Filme.

Cossío Woodward, Miguel. Sacchario. La Habana: Casa de las Américas, 1970. Impreso.

De bateyes. Dir. Sara Gómez. Distribuidora desconocida, 1971. Filme.

DeMoler. Dir. Alejandro Ramírez Anderson. Distribuidora desconocida, 2004. Filme.

Deschamps Chapeaux, Pedro. "Autenticidad de algunos negros y mulatos de Cecilia Valdés". Cecilia Valdés o La loma del Ángel de Cirilo Villaverde. Ed. Jean Lamore. Madrid: Ediciones Cátedra, 2012. Impreso.

Díaz Infante, Duanel. “Azúcar y revolución (Réquiem)”. Diario de Cuba. 10 de enero del 2016. Red. 9 nov. 2017.

Diego, Eliseo. "Pequeña historia de Cuba". Obra poética. Comp. Josefina de Diego. Ciudad Habana: Ediciones Unión, 2001. Impreso. 
Escobedo, Alonso de. "La Florida". Literatura cubana: entre el viejo y el mar de Ángel Esteban. Granada: Editorial Renacimiento, 2006. Impreso.

Esta tierra nuestra. Dir. Tomás Gutiérrez Alea. Distribuidora desconocida, 1959. Filme.

Esteban, Ángel. Literatura cubana: entre el viejo y el mar. Granada: Editorial Renacimiento, 2006. Impreso.

Fariñas Acosta, Lisandra. "Termina la zafra azucarera y crece un 20\%". Granma 30 de mayo de 2017. Red. 4 jun. 2017.

Febles Hernández, Miguel. "Abre Camagüey dos frentes de molienda". Granma 23 de diciembre de 2015. Red. 5 ago. 2016.

Fernández, Enrique. "Transformaciones del batey azucarero". Seminario de la cultura del azúcar en Cuba. Catauro Revista Antropológica Cubana 6.11 (2005): 34-40. Impreso.

Fernández Prieto, Leida. "Crónica anunciada de una Cuba azucarera". Francisco Arango

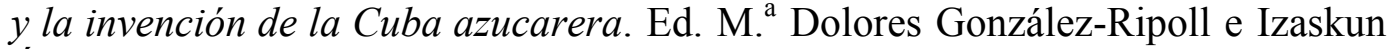
Álvarez Cuartero Salamanca: Ediciones Universidad de Salamanca, 2009. Impreso.

Fonseca Ramos , Mailén. El dulce hábito de hablar. 2014. Video-instalación.

Foucault, Michel. Nietzsche, la genealogía, la historia. Trad. José Vázquez Pérez. Valencia: Pre-textos, 2008. Impreso.

---. “Of Other Spaces (1967), Heteropias”. Foucaultinfo. Red. 11 ene. 2018.

Friedländer, Heinrich. Historia económica de Cuba. Ciudad de la Habana: Editorial de Ciencias Sociales, 1978. Impreso.

Frías y Jacott, Francisco de. "Carta XXII. De qué modo pueden consolidarse la riqueza y la prosperidad de la agricultura cubana". Reformismo Agrario. La Habana: Publicaciones de la Secretaria de Educación Dirección de Cultura, 1937. Impreso.

Gaceta Oficial. Decreto-Ley No. 287 "De la Extinción del Ministerio del Azúcar”. 28 de octubre de 2011. Impreso.

---. Decreto No. 294. 29 de octubre de 2011. Impreso.

---. Ley No. 851.7 de julio de 1960. Impreso. 
---. Primera Ley de Reforma Agraria. 3 de junio de 1959. Impreso.

Gallardo Saborido, Emilio José. El martillo y el espejo: Directrices de la política cultural cubana (1959 - 1976). Madrid: CSIC, 2009. Impreso.

García Gutiérrez, Ventura de Jesús. "El legado de Triunvirato". Granma 4 de noviembre de 2015. Red. 9 ago. 2016.

---. "Zafra: Vale mucho iniciar bien". Granma 21 de octubre de 2014. Red. 8 ago. 2016.

García Mora, Luis Miguel y Antonio Santamaría García. "Donde cristaliza la esperanza: lectura de los ingenios". Los ingenios: colección de vistas de los principales ingenios de azúcar de la Isla de Cuba. Ed. Luis Miguel García Mora y Antonio Santamaría García. Madrid: Centro de Estudios y Experimentación de Obras Públicas, 2005. 19-86. Impreso.

Goldberg, David Theo. Racist Culture: Philosophy and the Politics of Meaning. Oxford: Blackwell, 1993. Impreso.

---. The Racial State: Malden, MA: Blackwell Publishing, 2006. Impreso.

Gómez de Avellaneda, Gertrudis. Sab. Barcelona: Red Ediciones, 2011. Formato Digital.

González Martínez, Ortelio. "Zafra chica para moler en grande". Granma 23 de diciembre de 2016. Red. 4 nov. 2017.

González-Corzo. Mario. "Introducción". La agroindustria cañera: transformaciones recientes. Ed. Mario González-Corzo. New York: Bildner Center for Western Hemisphere Studies, 2015. Impreso.

---. "La agroindustria cañera: desempeño y tendencias recientes". La agroindustria cañera: transformaciones recientes. Ed. Mario González-Corzo. New York: Bildner Center for Western Hemisphere Studies, 2015. Impreso.

Guerra, Lillian. Visions of Power in Cuba: Revolution, Redemption, and Resistance, 1959-1971. Chapel Hill: University of North Carolina Press, 2012. Impreso.

Guerra Sánchez, Ramiro. Azúcar y población en las Antillas. La Habana: Editorial de Ciencias Sociales del Instituto del Libro, 1970. Impreso.

Guevara, Ernesto "Che". El socialismo y el hombre en Cuba. La Habana: Instituto del libro, 1967. Impreso.

Gutiérrez Alea, Tomás. "Esta tierra nuestra: documental sobre la Reforma agraria". Lunes de revolución 15 (22 de junio de 1959): 5-7. Red. 27 ene. 2018. 
Haraszti, Miklós. The Velvet Prison: Artists under State Socialism. Trad. Katalin y Stephen Landesmann. London: I.B. Tauris \& Co Ltd, 1988. Impreso.

Heredia, José María. “A Emilia”. Poemas de Heredia. Barcelona: Red Ediciones, 2011. Formato Digital.

---. “Al océano”. Poemas de Heredia. Barcelona: Red Ediciones, 2011. Formato Digital.

---. "Al salto del Niágara". Poemas de Heredia. Barcelona: Red Ediciones, 2011. Formato Digital.

---. “Al sol”. Poemas de Heredia. Barcelona: Red Ediciones, 2011. Formato Digital.

---. “Composición poética”. Poemas de Heredia. Barcelona: Red Ediciones, 2011. Formato Digital.

---. "En el Teocalli de Cholula”. Poemas de Heredia. Barcelona: Red Ediciones, 2011. Formato Digital.

---. "En una tempestad." Poesía completa. Ed. Carmen Alemany Bay. Madrid: Editorial Verbum, 2004. 126-128. Impreso.

---. "Himno del desterrado". Poemas de Heredia. Barcelona: Red Ediciones, 2011. Formato Digital.

Héroes del trabajo. Dir. Sergio Giral. Distribuidora desconocida, 1964. Filme.

Hombres del cañaveral. Dir. Pastor Vega. Distribuidora desconocida, 1965, Filme.

Humboldt, Alexander von. Ensayo politico sobre la Isla de Cuba. Caracas: Ayacucho, 2005. Impreso.

Inness, George. The Lackawanna Valley. 1855. Óleo sobre tela. National Gallery of Art, Washington D.C.

Jefferson, Thomas. "Declaration of Independence". Journal of the Continental Congress (1776). www.loc.gov. 5 may. 2017.

La primera carga al machete. Dir. Manuel Octavio Gómez. Tricontinental Film Center, 1969. Filme.

Labrador Herrera, Leidys María. "Continúan preparativos para la próxima zafra azucarera". Granma 11 de octubre de 2015. Red. 27 jul. 2016. 
Lapique Becali, Zoila. La memoria en las piedras. La Habana: Ediciones Boloña, 2002. Impreso.

Lázaro, Felipe. “Introducción”. El regalo de Nelson Rodríguez Leyva. Madrid: Editorial Betania, 2015. 7-14. Impreso.

Lazo, Raimundo. El Romanticismo: lo romántico en la lírica hispanoamericana. México, D.F.: Editorial Porrúa, 1971. Impreso.

Leerssen, Joep. "Notes Towards a Definition of Romantic Nationalism". Romantik: Journal for the Study of Romanticisms 2.1 (2013): 9-35. Impreso.

Leiner, Marvin. Sexual Politics in Cuba: Machismo, Homosexuality, and AIDS. Boulder, CO: Westview Press, 1994. Impreso.

Luben, Lino. "Más centrales incorporados a la zafra en Cuba". Granma 7 de diciembre de 2016. Red. 15 may. 2017.

Lucía. Dir. Humberto Solás. Tricontinental Film Center, 1968. Filme.

Luis, William. Literary Bondage: Slavery in Cuban Narrative. Austin: University of Texas Press. 1990. Impreso.

Machover, Jacobo. La memoria frente al poder. Escritores cubanos en el exilio: Guillermo Cabrera Infante, Severo Sarduy, Reinaldo Arenas. Valencia: Universidad de Valencia, 2001. Impreso.

Marqués de Armas, Pedro. "Psiquiatría para el nuevo Estado (1959-1972)". La Habana Elegante. Red. 18 ene. 2018.

Martínez Hernández, Leticia. "Economía cubana creció un 4\%". Granma 20 de diciembre de 2015. Red. 2 ago. 2016.

Martínez Molina, Julio. "Alistan los cinco centrales cienfuegueros para el comienzo de la zafra". Granma 13 de noviembre de 2014. Red. 2 ago. 2016.

---. "El circo nacional monta su carpa en Cienfuegos". Granma 18 de enero de 2015. Red. 5 ago. 2016.

---. "Presentan libros en bateyes azucareros". Granma 15 de junio de 2014. Red. 2 ago. 2016.

Marx, Leo. The Machine in the Garden: Technology and the Pastoral Ideal in America. New York: Oxford University Press, 2000. Formato Digital. 
Matamoros, Mercedes. "La canción a las cañas". Arpas cubanas (Poetas contemporáneos). La Habana: Imprenta de Rambla, 1904. Red. 20 ene. 2018.

Matušková, Magdalena. "Las UMAP y la Revolución: el papel de la plantación en El central y Arturo, la estrella más brillante de Reinaldo Arenas”. Mester 43.1 (2014): 17-40. Impreso.

Melaza. Dir. Carlos Lechuga. Distribuidora desconocida, 2012. Filme.

Merleaux, April. Sugar and Civilization: American Empire and the Cultural Politics of Sweetness. University of North Carolina Press, 2015. Impreso.

Mesa-Lago, Carmelo. Breve historia económica de la Cuba socialista: políticas, resultados y perspectivas. Madrid: Alianza Editorial, 1994. Impreso.

---. Cuba After the Cold War. Pittsburgh: University of Pittsburgh Press, 1993. Impreso.

---. "Problemas sociales y económicos en Cuba durante la crisis y la recuperación". Revista de la Cepal 86 (2005): 183-205. Red. 16 dic. 2017.

Ministerio del Azúcar (MINAZ). "Documento Programático". Recopilado por Maylán Álvarez en La callada molienda. La Habana: Ediciones La Memoria, 2012. Impreso.

---. Programa para la incorporación al estudio de 100 mil trabajadores del Minaz. Recopilado por Maylán Álvarez en La callada molienda. La Habana: Ediciones La Memoria, 2012. Impreso.

Mintz, Sidney W. Sweetness and Power: The Place of Sugar in Modern History. New York: Penguin Books, 1985. Impreso.

Miralles, Francisco. "Intervenciones". Seminario de la cultura del azúcar en Cuba. Catauro Revista Antropológica Cubana 6.11 (2005): 91-93. Impreso.

Molina, Marcel. Desnundando el tiempo (Serie). Serigrafía. 2009.

---. "El paraíso" (de la serie La raíz que no florece). Xilografía. 2010.

---. “El testamento". Xilografía. 2012.

---. “Memorias” (de la serie La raíz que no florece). Xilografía. 2010.

Monte adentro. Dir. José Antonio Jorge. Distribuidora desconocida, 1965. Filme.

Moreno Fraginals, Manuel. El ingenio: complejo económico social cubano del azúcar. 
Barcelona: Editorial Crítica, 2010. Impreso.

Morillas, Pedro José. "El ranchador”. Ed. Ingry González. La Habana: Editorial Letras Cubanas, 2009. Impreso.

Naranjo Orovio, Consuelo y Armando García González. Racismo e inmigración en Cuba en el siglo XIX. Madrid: Ediciones Doce Calles, 1996. Impreso.

Nietzsche, Friedrich. Sobre la utilidad y el perjuicio de la Historia para la vida. Trad. Germán Cano. Madrid: Biblioteca Nueva, 1999. Impreso.

Nora, Pierre. Los lugares de la memoria. Trad. Laura Masello. Santiago de Chile: Trilce, 2009. Impreso.

Novás Calvo, Lino. Pedro Blanco, el negrero. La Habana: Editorial Letras Cubanas, 1997. Impreso.

Ocasio, Rafael. A Gay Cuban Activist in Exile: Reinaldo Arenas. Gainesville: University Press of Florida, 2007. Impreso.

Oro de Cuba. Dir. Alejandro Saderman. Distribuidora desconocida, 1965. Filme.

Ortiz, Fernando. Contrapunteo cubano del tabaco y el azúcar. Madrid: Ediciones Cátedra, 2002. Impreso.

Osio, José de Jesús del. “Amor patrio”. Biblioteca del Soneto. Cervantes Virtual. Red. 15 nov. 2017.

Pastor, Beatriz. Discursos narrativos de la conquista: mitificación y emergencia. Ediciones del Norte: Hanover, 1988. Impreso.

Peña Castellanos, Lázaro. "La inserción de la agroindustria cañera cubana en la economía internacional". La agroindustria cañera: transformaciones recientes. Ed. Mario González-Corzo. New York: Bildner Center for Western Hemisphere Studies, 2015. Impreso.

Pérez-López, Jorge. The Economics of Cuban Sugar. Pittsburgh: University of Pittsburgh Press, 1991. Impreso.

Peters, Philip. "Cutting Losses: Cuba Downsizes its Sugar Industry". Lexington Institute, 1 de diciembre de 2003. Red. 24 ago. 2016.

Pichardo Moya, Felipe. "El poema de los cañaverales". La poesía lírica en Cuba. Tomo $V$, editado por José Manuel Carbonell. La Habana: Imprenta "El siglo XX", 1928. Red. 16 dic. 2017. 
Portela, Armando H. y Joseph L. Scarpaci. Cuban Landscapes: Heritage, Memory, and Place. New York: The Guilford Press, 2009. Formato digital.

Puig-Samper, Miguel Ángel. "Un edén ilustrado bajo el cielo de los trópicos". Francisco Arango y la invención de la Cuba azucarera. Ed. M. ${ }^{\mathrm{a}}$ Dolores González-Ripoll e Izaskun Álvarez Cuartero. Salamanca: Ediciones Universidad de Salamanca, 2009. 325-336. Impreso.

Reed, Roger. The Cultural Revolution in Cuba. Ginebra: Latin American Round Table, 1991. Impreso.

Redacción Nacional del Granma. "Dulces noticias". Granma 30 de diciembre del 2014. Red. 22 ago. 2016.

Ricoeur, Paul. La memoria, la historia, el olvido. Trad. Agustín Neira. Buenos Aires: Fondo de Cultura Económica, 2013. Impreso.

Rivera Pagán, Luis N. "Bartolomé de las Casas y la esclavitud africana". Sentido histórico del $V$ Centenario, 1492-1992. Ed. Guillermo Meléndez. San José: Editorial Departamento Ecuménico de Investigaciones, 1992. Impreso.

Riverend, Julio de. La República: dependencia y revolución. La Habana: Editorial de Ciencias Sociales, 1975. Impreso.

Rodríguez Calviño, Maikel José. "Ecos del Morera: elogios de lo tridimensional". Escambray. 6 de noviembre de 2014. Red. 1 sep. 2016.

Rodríguez, Luis Felipe. Marcos Antilla: relatos de cañaveral. La Habana: Instituto cubano del libro, 1971. Impreso.

Rodríguez Leyva, Nelson. El regalo. Madrid: Editorial Betania, 2015. Impreso.

Rojas, Rafael. Isla sin fin: Contribución a la crítica del nacionalismo cubano. Miami: Ediciones Universal, 1998. Impreso.

Ros, Enrique. La UMAP: el gulag castrista. Miami: Ediciones Universal, 2004. Impreso.

Ruskin, John. Modern Painters. Volume 3. London: Smith, Elder and Co., 1872. Red. 15 abr. 2017.

Saco, José Antonio. “Análisis por don José Antonio Saco de una obra sobre el Brasil, intitulada, Notices of Brazil in 1828 and 1829 by Rev. R. Walsh author of a journey from Constantinople, etc. (Noticias del Brasil en 1828 y 1829 por el presbítero R. Walsh, autor de un viaje a Constantinopla, etc.)". Colección de 
papeles científicos, históricos, políticos, y de otros ramos sobre la Isla de Cuba ya publicados, ya inéditos por Don José Antonio Saco. Tomo II. Paris: Imprenta de D’Aubusson y Kugelmann, 1958. Impreso.

Sanguinetty, Jorge A. "La industria". 40 años de Revolución: el legado de Castro. Ed. Efrén Córdoba. Miami: Ediciones Universal, 1999. Impreso.

Santa Cruz, María. “Adiós a la Macagua”. Noches literarias en casa de Nicolás Azcarate. Vol. I. La Habana: Imprenta La Antilla: 1866. Red. 15 ene. 2018.

Santamaría García, Antonio. “Azúcar y revolución: el sector azucarero de la economía cubana durante los primeros doce años de la Revolución (1959-1970)". Revista de historia económica 12.1 (1994): 111-141. Red. 2 feb. 2018.

---. “Colonos. Agricultores cañeros, ¿clase media rural en Cuba? 1880-1898”. Revista de Indias 58.212 (1998): 131-161. Red. 2 feb. 2018.

---. “La revolución cubana y la economía 1959-2012: los ciclos de política y el ciclo azucarero". Anuario de Estudios Americanos 71.2 (2014): 691-723. Red.

---. y Alejandro García Álvarez. Economía y colonia: La economía cubana y la relación con España, 1765-1902. Madrid: CSIC, 2004. Impreso.

Santiago, Fabiola. "Artist pair portrays ruins of Cuba's sugar industry". Miamibiennale. 7 de enero de 2005. Red. 15 nov. 2017.

Sartre, Jean Paul. El huracán sobre el azúcar. Montevideo: Ediciones Uruguay, 1961. Impreso.

Saumell, Rafael E. "Prólogo". El regalo de Nelson Rodríguez Leyva. Madrid: Editorial Betania, 2015. 15-30. Impreso.

Serra, Ana. The "new Man" in Cuba: Culture and Identity in the Revolution. Gainesville: University Press of Florida, 2007. Impreso.

Serrano León, Isabel. "El libro de Los ingenios, reflejo de la producción material del siglo XIX en Cuba". Revista de la Biblioteca Nacional José Martí 21.1 (1979): 85-110. Impreso.

Schama, Simon. Landscape and Memory. New York: Random House, 1995. Impreso.

Sierra Madero, Abel. "Academias para producir machos en Cuba". Letras libres (21 ene. 2016). Red.

Straet, Jan van der. América. Cir. 1575. Grabado. National Gallery of Art, Washington 
D.C.

Suárez Pérez, Eugenio y Acela Caner Román. "Cuba dispuso la nacionalización: en defensa de la economía y soberanía del país". Granma. 5 de agosto de 2015. Red. 1 sep. 2016.

Suárez Romero, Anselmo. Francisco, el ingenio o Las delicias del campo. Sevilla: Editorial Doble J, 2009. Impreso.

---. "Los ingenios". Colección de artículos de Anselmo Suárez Romero. La Habana: Establecimiento Tipográfico La Antilla, 1859. Impreso.

Sulroca Domínguez, Federico. "AZCUBA: un nuevo modelo de la agroindustria cañera cubana". La agroindustria cañera: transformaciones recientes. Ed. Mario González-Corzo. New York: Bildner Center for Western Hemisphere Studies, 2015. Impreso.

Tahbaz, Joseph. "Demystifying las UMAP: The Politics of Sugar, Gender, and Religion in 1960s Cuba". Delaware Review of Latin America Studies 4.2 (December 31, 2013). Red. 17 feb. 2018.

United States Department of Agriculture (USDA). "World Production, Suply and Distribution”. Sugar and Sweeteners Yearbook Tables. 2018. Red. 19 feb. 2018.

Valdés Paz, Juan. "Intervenciones". Seminario de la cultura del azúcar en Cuba. Catauro Revista Antropológica Cubana. 6.11 (2005): 80-81. Impreso.

Varela y Morales, Félix. "Proyecto de decreto sobre la abolición de la esclavitud en la Isla de Cuba y sobre los medios de evitar los daños que pueden ocasionarse a la población blanca y a la agricultura". Félix Varela y Morales. Obras (Volumen II). Ciudad de La Habana: Ediciones Imagen Contemporánea, 2001. Impreso.

---. "Proyecto y Memoria para la extinción de la esclavitud en la Isla de Cuba". Félix Varela y Morales. Obras (Volumen II). Ciudad de La Habana: Ediciones Imagen Contemporánea, 2001. Impreso.

---. "Faltaron control y exigencia en la zafra". Granma. 5 de mayo de 2010. Red. 7 ago. 2016.

---. "Positiva primera etapa de la reestructuración azucarera". Granma 20 de diciembre de 2002. Recopilado por Maylán Álvarez en La callada molienda. Red.

Venegas Fornias, Carlos. "El libro de Los Ingenios". Agua, trabajo y azúcar: actas del Sexto Seminario Internacional sobre la caña de azúcar. Ed. Antonio Malpica. Granada: Diputación Provincial de Granada. 1996. Impreso. 
Viera, Félix Luis. Un ciervo herido. San Juan: Editorial Plaza Mayor, 2002. Impreso.

Villaverde, Cirilo. Cecilia Valdés o La loma del Ángel. Ed. Jean Lamore. Madrid: Ediciones Cátedra, 2012. Impreso.

---. Excursión a Vuelta Abajo. Ciudad de la Habana: Editorial Letras Cubanas, 1981. Impreso.

---. Diario del rancheador. Ciudad de la Habana: Editorial Letras Cubanas, 1982. Impreso.

Walon, Alberto G. "Preparativos de zafra en Mayabeque". Granma. 28 de septiembre de 2014. Red. 5 ago. 2016.

“Zafra cubana puede producir más azúcar”. Granma. 6 de enero de 2017. 18 may. 2017.

Zanetti Lecuona, Oscar. "Historia y azúcar". Seminario de la cultura del azúcar en Cuba. Catauro Revista Antropológica Cubana 6.11 (2005): 15-25. Impreso.

---. "Las manos en el dulce: estado e intereses en la regulación de la industria azucarera cubana, 1926-1937. La Habana: Editorial de Ciencias Sociales, 2004. Impreso.

Zanetti Lecuona, Oscar y Alejandro García Álvarez. Caminos para el azúcar. La Habana: Editorial de Ciencias Sociales, 1987. Impreso.

Zéndegui, Ileana C. Entre el terror y la irrealidad: la narrativa poética postmoderna de Reinaldo Arenas. 2003. Florida International University. Disertación Doctoral. 
VITA

\title{
DÉBORAH GÓMEZ
}

\author{
Born, Havana, Cuba
}

2013-2018

Doctoral Candidate

Teacher Assistant

FIU Dissertation Year Fellowship (Fall 2017 and Spring 2018)

FIU Doctoral Evidence Acquisition Fellowship (Spring 2017)

Tinker Foundation Field Research Grant (Spring 2016)

Pablo Ruiz Orozco and Miguel Quesada Memorial Scholarship (Fall 2014)

Modern Languages

Florida International University

Miami, Florida

2013

M.A. Spanish

Award for Outstanding Academic Achievement (Summer 2013)

Modern Languages

Florida International University

Miami, Florida

1997

B.A in German Language and Literature

University of Havana, Havana, Cuba

\section{PUBLICATIONS AND PRESENTATIONS}

Gómez, Déborah. Esta tierra nuestra (This land of ours). The Encyclopedia of Cuban Cinema. Rowman and Littlefield. (Under contract, anticipated to go into press 2019).

Gómez, Déborah. Daimón: el carnaval totalizante y primitivista de Abel Posse, como continuidad de la estética del realismo mágico. Circunloquios, Revista de Investigaciones Culturales, Tempe, AZ, June 2015.

Gómez, Déborah. "Cierre y desmantelamiento de los centrales azucareros: representación y memoria a través del nuevo audiovisual cubano del siglo XXI". Reading Cuba: An Interdisciplinary Conference on Cuban and Cuban American Literature. November 2016. Florida International University, Miami, FL 
Gómez, Déborah. "Diminished black students enrollment in Spanish courses: The current situation in the US". XXXIV International Congress of the Latin American Studies Association. May 2016. Latin American Studies Association (LASA), New York, NY

Gómez, Déborah. "El ranchador de Pedro José Morillas: Tres figuras que imposibilitan la reconciliación de lo cubano" Nineteenth-Century Latin American and Spanish Literature Conference. November 2015. Florida International University, Miami, FL 